\title{
Systematics and biogeography of the genus Phalloceros Eigenmann, 1907 (Cyprinodontiformes: Poeciliidae: Poeciliinae), with the description of twenty-one new species
}

\author{
Paulo Henrique Franco Lucinda
}

The genus Phalloceros is revised. Phalloceros caudimaculatus (Hensel, 1868) and twenty-one new species are recognized in Phalloceros. The species and their distributions are: P. alessandrae, small coastal drainages of the Paraná State; P. anisophallos, small coastal drainages of the Rio de Janeiro State; P. aspilos, rio Parati-Mirim, Rio de Janeiro; P. buckupi, small coastal drainages of the Paraná State; P. caudimaculatus (Hensel, 1868), laguna dos Patos system, lower rio Uruguay, drainages of rio Tramandaí, rio Mampituba and coastal drainages of Uruguay and Argentina; P. elachistos, rio Doce drainage and small coastal drainages of the Espírito Santo State; P. enneaktinos, córrego da Toca do Boi, Rio de Janeiro; P. harpagos, rio Paraná-Paraguai basin and coastal drainages from Espírito Santo to Santa Catarina States; P. heptaktinos, rio Jacuí drainage; P. leptokeras, middle portions of rio Paraíba do Sul drainage; P. leticiae, upper rio Araguaia; P. lucenorum, rio Juquiá drainage; P. malabarbai, coastal drainage of the Santa Catarina State; P. megapolos, drainages of rio São João, rio Cubatão (North) and small adjacent drainages of the Paraná State; P. mikrommatos, rio João de Tiba basin, a coastal drainage of the Bahia State; P. ocellatus, coastal drainages of the Bahia and Espírito Santo States; P. pellos, small coastal drainages of the Paraná State; P. reisi, headwaters of rio Tietê, rio Paraíba do Sul, rio Ribeira de Iguape, and small coastal drainages of the São Paulo State; $P$. spiloura, coastal drainages of the Rio Grande do Sul and Santa Catarina States; P. titthos, coastal drainages of the Paraná State; $P$. tupinamba, rio Itamambuca and rio Macacu drainages, small coastal drainages of the São Paulo and Rio de Janeiro States, and P. uai, rio São Francisco basin. A lectotype for Girardinus caudimaculatus is designated. Diagnoses of intrageneric clades of Phalloceros are provided. Diagnoses and descriptions of distributions are provided for each species as well as a key for identification. Phylogenetic and biogeographical features of Phalloceros are discussed.

O gênero Phalloceros é revisado. Phalloceros caudimaculatus (Hensel, 1868) e vinte e uma espécies novas são reconhecidas em Phalloceros. As espécies e suas distribuições são: P. alessandrae, pequenas bacias costeiras do Estado do Paraná; $P$. anisophallos, pequenas bacias costeiras do Estado do Rio de Janeiro; P. aspilos, rio Parati-Mirim, Rio de Janeiro; P. buckupi, pequenas bacias costeiras do Estado do Paraná; P. caudimaculatus (Hensel, 1868), sistema da Laguna dos Patos, baixo rio Uruguai, bacias dos rios Tramandaí, Mampituba e drenagens costeiras do Uruguai e Argentina; P. elachistos, drenagem do rio Doce e pequenas bacias costeiras do Estado do Espírito Santo; P. enneaktinos, córrego da Toca do Boi, Rio de Janeiro; $P$. harpagos, bacia do rio Paraná-Paraguai e bacias costeiras do Espírito Santo a Santa Catarina; P. heptaktinos, bacia do rio Jacuí; P. leptokeras, porção média da bacia do rio Paraíba do Sul; P. leticiae, porção superior do rio Araguaia; $P$. lucenorum, drenagem do rio Juquiá; P. malabarbai, drenagem costeira do Estado de Santa Catarina; P. megapolos, drenagens dos rios São João, rio Cubatão (Norte) e pequenas drenagens adjacentes no Estado do Paraná; P. mikrommatos, bacia do rio João de Tiba, drenagem costeira do Estado da Bahia; P. ocellatus, drenagens costeiras dos Estados da Bahia e Espírito Santo; P. pellos, pequenas bacias costeiras do Estado do Paraná; P. reisi, cabeceiras do rio Tietê, rio Paraíba do Sul, rio Ribeira de Iguape, e pequenas bacias costeiras do Estado de São Paulo; P. spiloura, bacias costeiras dos Estados do Rio Grande do Sul e Santa Catarina; P. titthos, bacias costeiras do Estado do Paraná; P. tupinamba, bacias dos rios Itamambuca e Macacu, pequenas drenagens costeiras dos Estados de São Paulo e Rio de Janeiro e P. uai, bacia do rio São Francisco. Um lectótipo para Girardinus caudimaculatus Hensel, 1868 é designado. São apresentadas diagnoses dos clados intragenéricos de Phalloceros. Diagnoses e descrições das distribuições são apresentadas para cada espécie bem como uma chave de identificação. Aspectos filogenéticos e biogeográficos de Phalloceros são discutidos.

Key words: Phylogeny, Killifishes, Taxonomy.

Laboratório de Ictiologia Sistemática, Universidade Federal do Tocantins, Campus de Porto Nacional, Rua 3, Quadra 17, s/n, Caixa Postal 136, 77500-000 Porto Nacional, TO, Brazil. lucinda@uft.edu.br 


\section{Introduction}

Phalloceros Eigenmann, 1907 is a monotypic genus (Lucinda, 2003) comprising small poeciliin fishes broadly distributed throughout southern and southeastern river basins of South America. The taxonomic history of the genus Phalloceros began in 1868 with the description of Girardinus caudimaculatus Hensel, 1868. At that time, classification of the Cyprinodontiformes was very deficient. Poeciliine species known from South America were solely assigned to genera Poecilia Bloch \& Schneider, 1801, Heterandria Agassiz, 1853, and Girardinus Poey, 1854. “The Cyprinodonts” monograph of Garman (1895) represents the first attempt to extensively review the Cyprinodontiformes. Garman's (1895) classification was mainly based on tooth, jaw, and anal fin morphology. This author erected the genus Glaridodon Garman, 1895 under which he synonymized Girardinus caudimaculatus [= Phalloceros caudimaculatus] with $G$. januarius Hensel, 1868 [= Phalloptychus januarius]. Later, Eigenmann (1907) recognized $G$. januarius as generically distinct from $G$. caudimaculatus on the basis of teeth and gonopodium structure. Therefore, Eigenmann (1907) created the genus Phalloptychus Eigenmann, 1907 for Glaridichthys januarius, and erected the genus Phalloceros for $G$. caudimaculatus, both monotypic. Despite of this, some subsequent authors (e.g. Phillipi, 1908; Langer, 1913) considered
G. caudimaculatus a junior synonym of G. januarius. Alternatively, Regan (1913) and Henn (1916) following Eigenmann (1907) recognized the distinctness of genera Phalloceros and Phalloptychus (see Lucinda, 2005b for further details).

Phalloceros species are well known from several biological standpoints, being object of study for ecologists, anatomists, embryologists, and many others biology researchers. Despite of this, the genus Phalloceros is disappointingly illstudied from the perspective of systematics. Despite of its wide distribution, Phalloceros caudimaculatus is the only formally described species in the genus.

The intrageneric diversity and relationships remains unknown until now. Lucinda \& Reis (2005: fig. 3) depicted a general hypothesis of phylogenetic relationships among several unnamed Phalloceros species and P. caudimaculatus, as part of a more inclusive phylogenetic study on the relationships among poeciliine genera, including, the phylogenetic position of the genus Phalloceros in the subfamily Poeciliinae (Lucinda \& Reis, 2005: fig. 1). Although the transformation series analysis was provided by Lucinda \& Reis (2005), these authors did not present the diagnoses of intrageneric clades or describe the newly identified species. These clade diagnoses and species descriptions are provided herein (Fig. 1).

Thus, this paper has the following aims: (1) to describe and diagnose the species of Phalloceros and their geographic

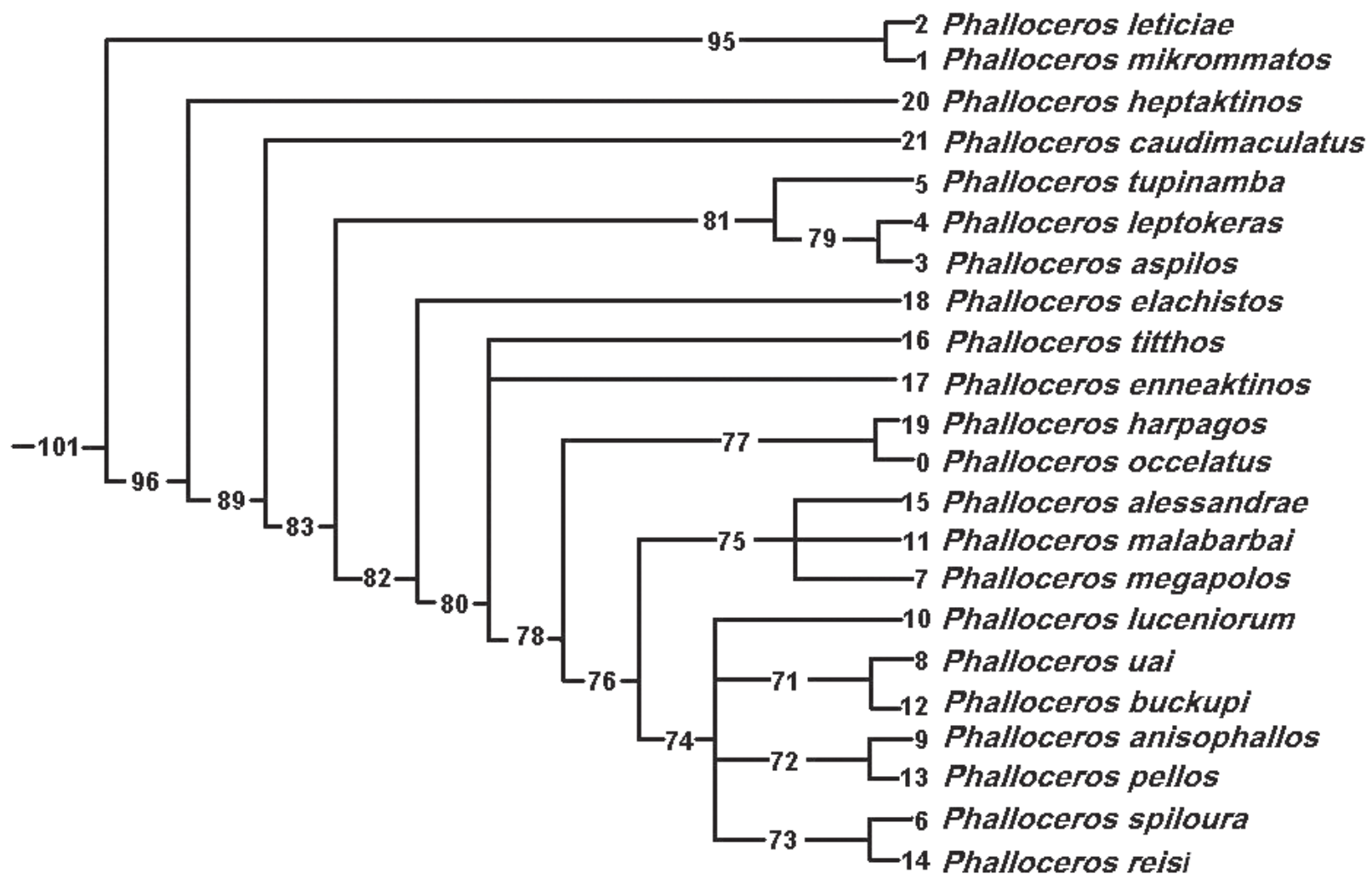

Fig. 1. Intrageneric relationships of Phalloceros species (Lucinda \& Reis, 2005). The numbers on the branches refer to the character state transformations series. 71: 18-0; 19-0; 64-4. 72: 75-1. 73: 128-1. 74: 66-1; 96-1*; 97-1; 99-2**. 75: 98-1**. 76: 143-1**. 77: 20-1; 135-1. 78: 37-0; 86-4. 79: 31-1; 86-4. 80: 18-2*; 19-2*. 81: 95-1**; 97-1; 143-2**. 82: 37-1; 95-2*; 128-2. 83: 99-1*. 85: 22-0. 89: 135-2. 95: 31-1; 128-2; 135-1.96: 21-0; 36-2; 38-1. 101: 2-1; 8-5**; 42-1; 53-4*; 79-0; 94-1**; 112-3*; 117-1; 119-1; 129-0. 
distribution; (2) present the diagnoses of the genus and its intrageneric clades; and (3) and to discuss the biogeographic history of those species.

\section{Material and Methods}

Museum acronyms are from Leviton et al. (1985), and Leviton \& Gibbs (1988) except for MHNCI: Museu de História Natural do Capão da Imbúia, Curitiba; UFPB: Universidade Federal da Paraíba, Departamento de Sistemática e Ecologia, João Pessoa; UNT: Laboratório de Ictiologia Sistemática, Universidade Federal do Tocantins, Porto Nacional; and ZVCP: Sección Vertebrados, Facultad de Ciencias, Montevideo.

In species descriptions, numbers in square brackets following the counts indicate number of specimens for each count, whereas an asterisk indicates primary type counts. The entries under examined material and all geographic descriptors (including country) follow Lucinda (2005a and b). The abbreviations E, W, S, and $\mathrm{N}$ are used respectively for East, West, South and North. Due to economy of space, several lots collected in the same locality or in very close localities were omitted. The whole list of examined specimens is available with the author and can be obtained upon request.

In the etymology of new specific epithets, the following abbreviations were used: adj. = adjective; $\mathrm{n} .=$ noun; num. = numeral; $\mathrm{m}$. = masculine; $\mathrm{f}$. = feminine; sg. = singular; $\mathrm{pl}$. = plural; nom. = nominative; gen. = genitive; i.f. = indeclinable form. When the specific name is an adjective, the endings for the remaining genders are given in parentheses following the adjective.

Counts follow Lucinda (2005a and b), with the addition of the number of serrae on ray $4 \mathrm{p}$ of gonopodium; and with the modification on anal-fin ray counts for males, which also included the last, minute ray. Only branched rays were included in pectoral and caudal fin counts. All counts were made on the left side of adult specimens whenever possible. Adult males were considered those with a fully developed gonopodium. A fully developed gonopodium is that whose distal appendix is completely developed and lacks external coverage of skin.

Morphometric data were obtained as detailed in Lucinda (2005a and b). Clearing and staining followed the method of Taylor \& Van Dyke (1985). Anatomical illustrations were prepared from sketches of structures from cleared and stained specimens as viewed through a camera lucida mounted on a dissecting stereomicroscope. Number and disposition of cephalic pores follow the nomenclature of Rosen \& Mendelson (1960), Gosline (1949), and Parenti (1981). Only adult individuals have been examined to avoid undesirable ontogenetic variation. Nomenclature of the gonopodium follows Rosen \& Gordon (1953) modified by Lucinda \& Reis (2005). Descriptions of gonopodial morphology are based on fully developed gonopodia of large adult males. Anatomical nomenclature, other than gonopodial, follows Rosen \& Bailey (1963), Parenti (1981), and Rauchenberger (1989).

The phylogenetic species concept is followed: species are diagnosable and stable groups of organisms representing a stable lineage within a phylogenetic hypothesis. Therefore, species diagnoses are based on autapomorphies. Character state assignments, transformation series and clade numbers follow the phylogenetic analysis performed by Lucinda $\&$ Reis (2005). In the diagnoses uniquely derived and unreversed features are indicated by two asterisks (e.g. 53$\left.2^{* *}\right)$; uniquely derived features are indicated by one asterisk (e.g. 24-1*). Character state illustrations are provided or referred to by Lucinda \& Reis (2005).

\section{Results}

Twenty-two Phalloceros species are herein recognized: P. caudimaculatus (Hensel, 1868) and twenty-one new species, whose formal descriptions are provided below. Autapomorphies and synapomorphies supporting the monophyly of the genus and infrageneric clades are presented below as well.

\section{Genus Phalloceros Eigenmann, 1907}

Clade 101, Lucinda \& Reis (2005)

Phalloceros Eigenmann, 1907: 431. Masculine. Type-species: Girardinus caudimaculatus Hensel, 1868. Type by original designation and monotypy.

Diagnosis. Phalloceros species share the following uniquely derived and unreversed features: (1) preopercular canal present and partially closed: pores 8,9 , and 10 opened in a deep groove; pore 11 opened and elongate (sometimes confluent with groove 8,9 and 10) canal between pores 12, UV closed (sometimes canal U-V opened) [8-5**]; and (2) paired appendix at tip of R3 [93-1**].

Additionally, the genus Phalloceros can be diagnosed by the following not uniquely derived and/or reversed features: (1) parietals short restricted to epiotic region, not reaching sphenotic anteriorly [2-1]; (2) width of first pelvic-fin ray decreasing abruptly at distal portion, which is slender and long in adult males [41-1]; (3) gonapophysis of vertebra 14 bearing an abrupt break forming an acute angle at subdistal portion in adult males [52-4*];(4) anterior process on base of fifth middle anal-fin radial absent in adult males [78-0]; (5) large membranous tip anterior to R4 and R5 [111-3*]; (6) eight or more subdistal retrorse spines on R4p [116-1]; (7) elongate and dorsal protuberance along $\mathrm{R} 4 \mathrm{p}$ (just behind retrose spines series) [118-1]; and (8) distal portion of R6 not expanded [128-0].

\section{Phalloceros mikrommatos + P. leticiae Clade 95, Lucinda \& Reis (2005)}

Diagnosis. Phalloceros mikrommatos and $P$. leticiae share the following not uniquely derived and/or reversed features: (1) third basibranchial ossified and toothed [30-1]; (2) distal elements of R6 branches totally fused [127-2]; and (3) spot on median region of flanks rounded [134-1]. 


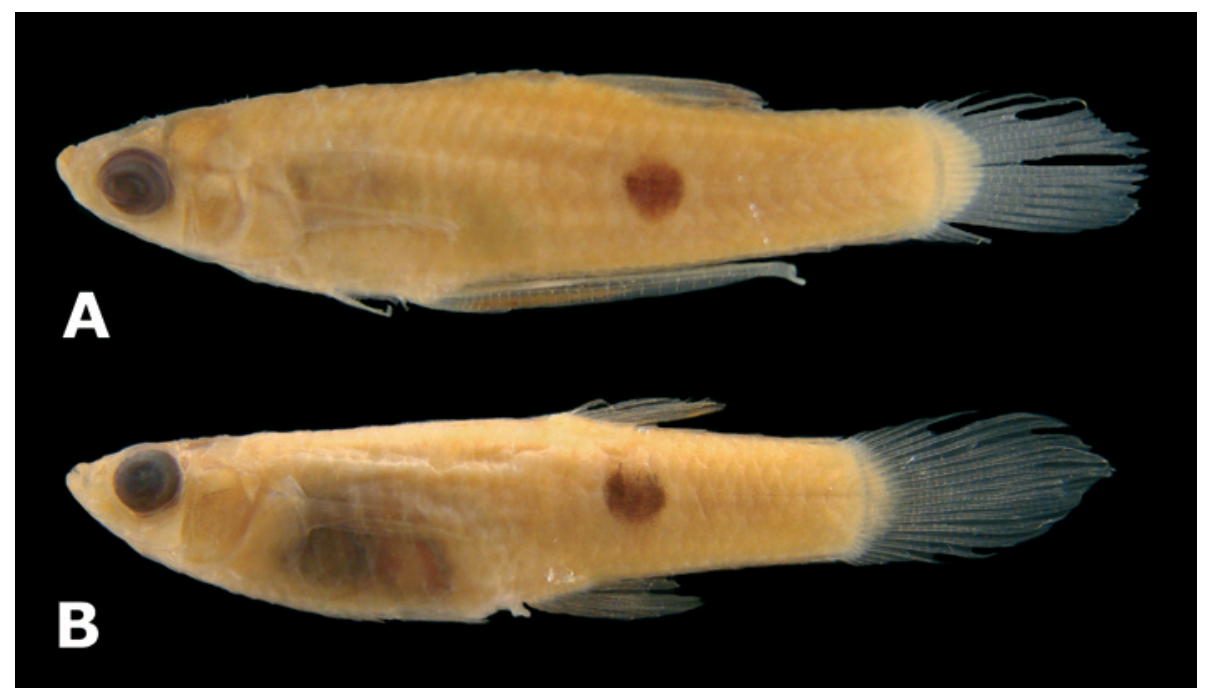

Fig. 2. Phalloceros mikrommatos. (A) Holotype, male, 20.4 mm SL, UFPB 5370, Porto Seguro, rio João de Tiba drainage, Estação Ecológica Pau Brasil; (B) paratype, female, UFPB 2748, 21.9 mm SL, collected with the holotype.

\section{Phalloceros mikrommatos, new species}

Figs. 2, 3

Phalloceros sp. n. C Lucinda \& Reis (2005).

Holotype. UFPB 5370, unnamed stream, rio João de Tiba drainage, Estação Ecológica Pau Brasil, 15 km NW from Porto Seguro, approximately $16^{\circ} 26^{\prime} \mathrm{S} 39^{\circ} 04^{\prime} \mathrm{W}$, Porto Seguro, Bahia, Brazil, $25 \mathrm{Feb}$ 1986, M.M. Oliveira \& R.T.C. Ramos.

Paratypes. BRAZIL. Bahia. UFPB 1751, 14, Porto Seguro, unnamed stream affluent to rio Camurigi, rio João de Tiba drainage, Estação Ecológica Pau Brasil, 15 km NW from Porto Seguro, 2 Mar 1986, R.T.C. Ramos. UFPB 1759, 7, same locality and collector of UFPB 1751, 19 Feb 1986. UFPB 2214/1*, 14 of 37, locality and collector of UFPB 1751, 27 Feb 1986. UFPB 2688, 4, riacho Ronca Água, rio João de Tiba drainage, Estação Ecológica Pau Brasil, 15 km NW from Porto Seguro, 17 Feb 1986, I. Lucena et al. UFPB 2710, 1, same locality and collector of UFPB 2688, 21 Feb 1986. UFPB 2718, 8, same locality of UFPB 2688, 22 Feb 1986, R.T.C. Ramos. UFPB 2724, 10, same locality and collector of UFPB 2718, 23 Feb 1986. UFPB 2748, 21/2*, collected with the holotype.
UFPB 2758, 7, same locality and collector of UFPB 2718, 26 Feb 1986. UFPB 2776, 5, same locality of UFPB 2748, 27 Feb 1986, R. T. C. Ramos.

Diagnosis. Phalloceros mikrommatos can be distinguished from its congeners by (1) the first gonapophysis angled 5-15 degrees relative to vertebral column [53-2]; and (2) second gonapophysis angled zero-15 degrees relative to vertebral column [54-3]. Phalloceros mikrommatos can be further distinguished from its congeners but $P$. leticiae and $P$. ocellatus by the roundish to round and well-defined ocellated lateral spot [134-1] (Fig. 2). Phalloceros mikrommatos can be distinguished from $P$. leticiae and $P$. ocellatus by the number of anal-fin rays in females (11 vs. 10, respectively).

Description. Morphometric data in Tables 1 and 2. Range of SL: 18.1 to $27.0 \mathrm{~mm}$ (females), 17.4 to $20.4 \mathrm{~mm}$ (males). Dorsalfin rays: $8 *$ [38], 9 [6]. Branched pectoral-fin rays: $6 *$ [16], 7 [1]. Pelvic-fin rays: 5* [11] (males), 5 [28] (females). Anal-fin rays of females: 11 [28]. Anal-fin rays of males: 9* [14].

Table 1. Descriptive morphometrics of female specimens of Phalloceros leptokeras, $P$. leticiae, $P$. megapolos, and $P$. mikrommatos. Measurements 1-10 are percents of standard length and measurements 11-13 are percents of head length.

\begin{tabular}{|c|c|c|c|c|c|c|c|c|}
\hline \multirow[t]{2}{*}{ Character } & \multicolumn{2}{|c|}{$\begin{array}{l}\text { Phalloceros leptokeras } \\
n=20\end{array}$} & \multicolumn{2}{|c|}{$\begin{array}{c}\text { Phalloceros leticiae } \\
\mathrm{n}=3\end{array}$} & \multicolumn{2}{|c|}{$\begin{array}{l}\text { Phalloceros megapolos } \\
\mathrm{n}=11\end{array}$} & \multicolumn{2}{|c|}{$\begin{array}{l}\text { Phalloceros mikrommatos } \\
\mathrm{n}=15\end{array}$} \\
\hline & Range & Mean & Range & Mean & Range & Mean & Range & Mean \\
\hline Standard length (mm) & $21.7-36.5$ & 30.1 & $18.4-21.4$ & 19.8 & $21.7-39.7$ & 27.4 & $18.1-27.0$ & 22.1 \\
\hline 1-Head length & $17.4-21.9$ & 19.5 & $23.0-26.5$ & 24.4 & $19.1-24.6$ & 21.8 & $20.3-24.1$ & 22.3 \\
\hline 2-Snout-occipital distance & $18.9-23.4$ & 20.7 & 19.7-22.1 & 20.6 & $14.5-20.9$ & 18.4 & 16.4-21.9 & 19.0 \\
\hline 3-Predorsal distance & $58.6-63.8$ & 61.3 & $61.9-64.1$ & 62.8 & $59.7-64.7$ & 62.4 & $59.7-64.0$ & 61.7 \\
\hline 4-Dorsal-fin base length & $5.8-11.7$ & 9.7 & $7.7-10.0$ & 8.9 & 9.1-11.9 & 10.8 & $7.8-11.5$ & 9.8 \\
\hline 5-Anal-fin base length & $7.5-12.3$ & 9.7 & $8.4-8.8$ & 8.6 & $8.5-11.7$ & 9.8 & 7.7-11.5 & 8.9 \\
\hline 6-Body depth & $23.3-27.1$ & 25.6 & $21.9-25.4$ & 23.8 & $24.0-28.3$ & 25.8 & $20.8-28.8$ & 24.1 \\
\hline 7-Pre-pelvic length & $37.4-46.0$ & 42.7 & $44.5-46.1$ & 45.2 & 41.9-46.6 & 43.9 & $42.2-46.4$ & 44.4 \\
\hline 8-Preanal length & $56.5-60.1$ & 58.5 & $57.9-58.0$ & 57.9 & $54.8-58.8$ & 56.9 & 56.9-62.9 & 59.0 \\
\hline 9-Postanal length & $33.4-38.7$ & 36.3 & $36.4-37.0$ & 36.6 & $35.0-39.7$ & 37.1 & 34.3-38.9 & 36.4 \\
\hline 10-Caudal peduncle depth & $12.7-15.7$ & 14.5 & $15.6-16.0$ & 15.8 & 14.1-16.9 & 15.6 & $14.6-17.9$ & 15.9 \\
\hline 11-Snout length & 16.6-30.9 & 21.9 & $22.4-24.2$ & 23.3 & $22.7-28.9$ & 26.2 & 19.9-29.2 & 24.1 \\
\hline 12-Orbital diameter & $34.6-43.9$ & 40.5 & 39.1-41.8 & 40.2 & $34.5-43.3$ & 38.8 & 36.3-45.9 & 41.8 \\
\hline 13-Postorbital length & $36.8-52.1$ & 44.7 & $39.2-42.2$ & 40.2 & $35.3-44.0$ & 38.7 & $31.0-43.9$ & 38.1 \\
\hline
\end{tabular}




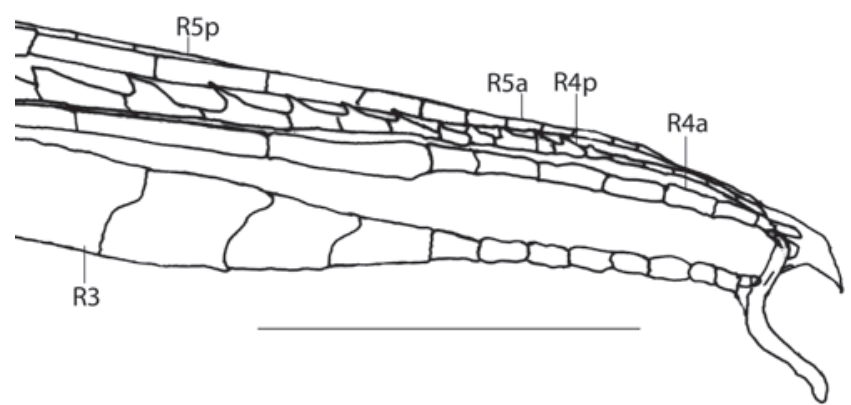

Fig. 3. Gonopodium tip of Phalloceros mikrommatos, UFPB 2214. R3, R4a, R4p, R5a, R5p indicate gonopodial rays. Scale bar $1 \mathrm{~mm}$.

Branched caudal-fin rays: 9 [2], 10* [16], 11 [10], 12 [1]. Predorsal scales: 14* [7]. Longitudinal series of scales: 28* [9]. Series of scales around caudal peduncle: $16^{*}$ [11]. Transverse series of scales: $7 *$ [12]. Serrae on R4p: 9 [1], 10 [6], 11* [3], 12 [3], 13 [1]. Epipleural ribs: 11 [1], 13 [1]. Pleural ribs: 13 [1], 14 [1]. Vertebrae: 31 [1], 32 [2]. Female urogenital papilla straight along midline, located along midventral line and between anus and base of first anal-fin ray. Hooks of gonopodial appendix absent (Fig. 3).

Color in alcohol. Eye dark iridescent grey with greenish brown pupil. Ground pale yellow. Upper two thirds of body and head densely covered with brown chromatophores. In some individuals these chromatophores more concentrated on longitudinal line region forming faint brown discontinuous band along flanks. Lower third of flanks pale yellow contrasting with upper, darker region. Border of scales and subjacent skin replete with brown chromatophores. Chromatophores more concentrated at short distance from scale border conferring reticulate pattern to body sides, mainly on upper half. Brown chromatophores scattered through whole body, more concentrated on dorsal portion, mainly on head, snout, opercle, and ventral surface of mandible. Ocellated lateral spot rounded or roundish encircled by light ring. Vertical bars along flanks inconspicuous or absent. Dorsal-fin membrane bearing faint band of brown chromatophores on distal border of dorsal fin. Faint band of chromatophores near dorsal-fin base. Pectoral-, pelvic-, and caudal-fin rays unpigmented. Dark brown line along R3. Anal fin of females hyaline; few chromatophores scattered through first three rays but not forming defined patch of pigmentation.

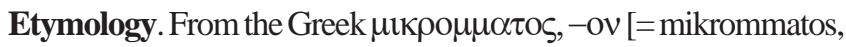
-on], (adj. m. nom. sg.) meaning small-eyed, alluding to the lateral spot, which is rounded and has an external light ring. An adjective.

Distribution. Phalloceros mikrommatos is known from the rio João de Tiba drainage, a coastal drainage in the Bahia State (Fig. 4).

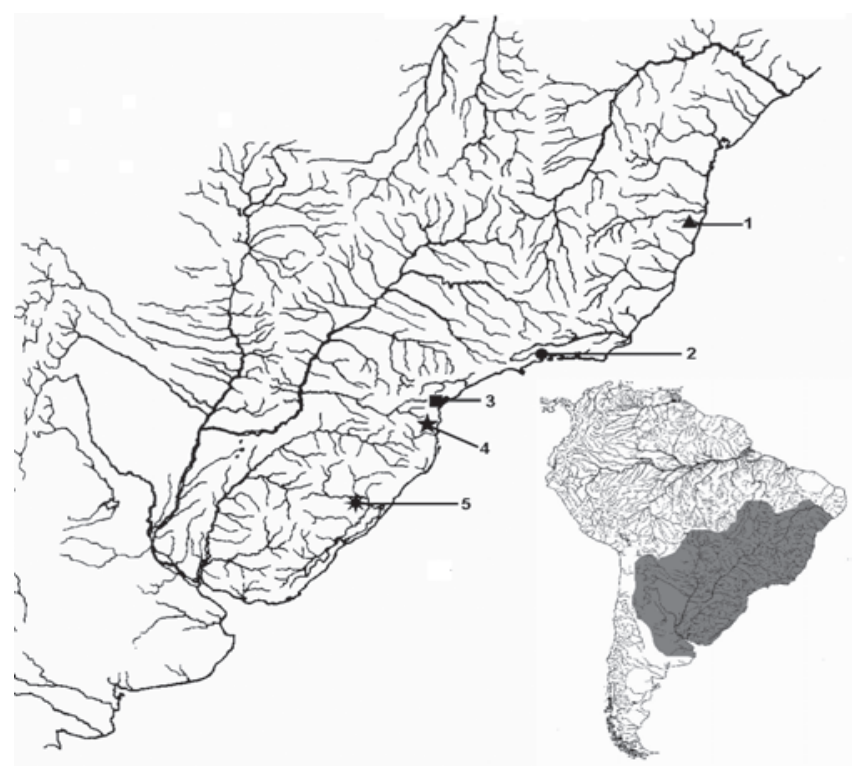

Fig. 4. Collection localities of Phalloceros mikrommatos (triangle, 1), P. enneaktinos (circle, 2), P. pellos (square, 3), $P$. malabarbai (five-pointed star, 4), and $P$. heptaktinos (eightpointed star, 5). Some symbols represent more than one lot or locality. Numbers represent type localities. The inset is the range of the genus.

\section{Phalloceros leticiae, new species \\ Figs. 5, 6}

Phalloceros sp. n. D Lucinda \& Reis, 2005.

Holotype. MCP 30551, rio Araguaia drainage, approximately 145ㄴ'S 510ㄴ'W, Aruanã, Goiás. Brazil. Apr 1983, R. La Corte.

Paratypes. BRAZIL. Goiás. MCP 30550, 2, and USNM 330339, $5 / 2 *$, collected with the holotype.

Diagnosis. Phalloceros leticiae can be distinguished from its congeners by (1) the presence of teeth on fourth ceratobranchial [27-0]; and (2) membranous tip anterior to R4 and R5 absent [111-0]. Additionally Phalloceros leticiae can be distinguished from its congeners, except $P$. mikrommatos and $P$. ocellatus, by the possession of a roundish to rounded and well-defined ocellated lateral spot (Fig. 5) [134-1] (rarely absent). Phalloceros leticiae can be distinguished from $P$. ocellatus by the postorbital length in females (39.2-42.2 \% SL vs. 24.8-39.3\% SL, respectively) and in males (36.7-42.3\% SL vs. 29.3-38.2 \% SL, respectively). Phalloceros leticiae can be distinguished from $P$. mikrommatos by the number of analfin rays in females (10 vs. 11, respectively).

Description. Morphometric data in Tables 1 and 2. Range of SL: 18.4-21.4 mm (females), 15.5-16.6 mm (males). Dorsal-fin rays: 7 [1], $8^{*}[6]$. Branched pectoral-fin rays: $6^{*}$ [6]. Pelvic-fin rays: $5 *$ [4] (males), 5 [3] (females). Anal-fin rays of females: 10 [3]. Anal-fin rays of males: 9* [3]. Branched caudal-fin 


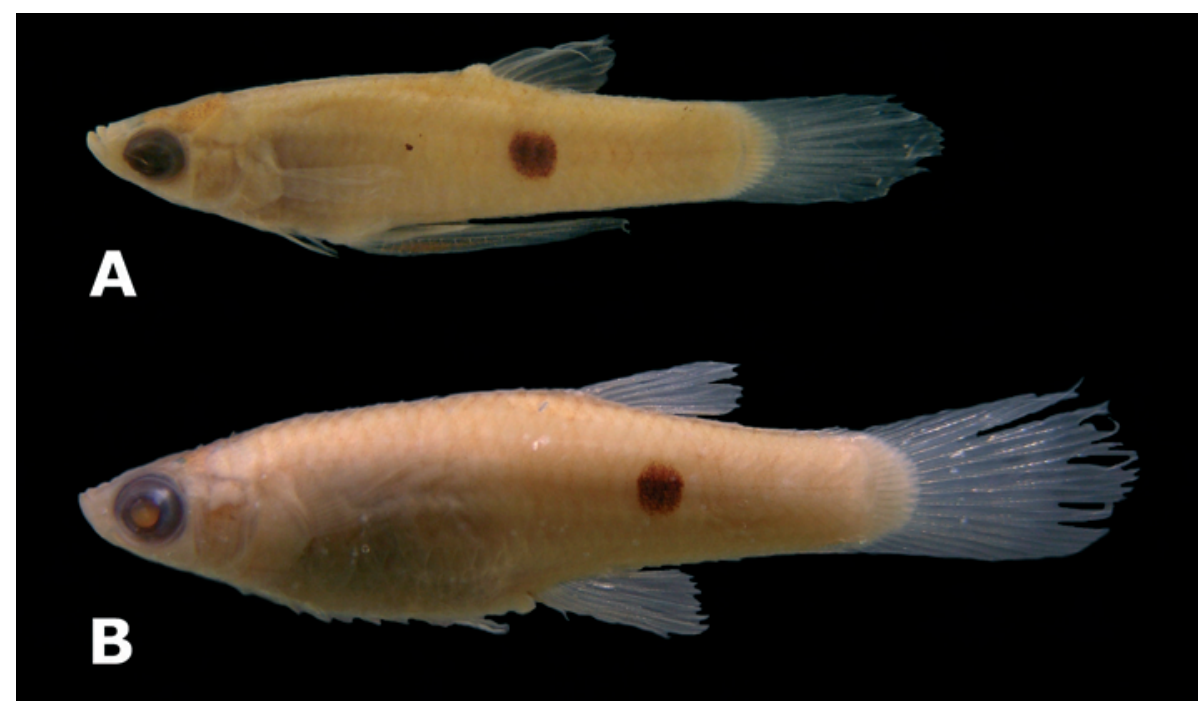

Fig. 5. Phalloceros leticiae. (A) Holotype, male, 16.2 mm SL, MCP 30551, Aruanã, rio Araguaia drainage. Goiás. Brazil; (B) paratype, female, $20.8 \mathrm{~mm}$ SL, MCP 30550, collected with the holotype.

rays: 10 [4], 11* [4]. Predorsal scales: 14 [2], 15* [3]. Longitudinal series of scales: $28 *$ [7]. Series of scales around caudal peduncle: $16 *[8]$. Transverse series of scales: $7 *$ [8]. Serrae on R4p: 9* [1], 11 [2]. Epipleural ribs: 12 [1], 14 [1]. Pleural ribs: 14 [2]. Vertebrae: 31 [2]. Female urogenital papilla straight along midline, located along midventral line and between anus and base of first anal-fin ray. Hooks of gonopodial appendix absent (Fig. 6).

Color in alcohol. Eye dark iridescent grey with greenish brown pupil. Ground color pale yellow. Upper two thirds of body and head densely covered with brown chromatophores. In some individuals these chromatophores more concentrated on longitudinal line region forming faint brown discontinuous band along flanks. Lower third of flanks pale yellow contrasting with upper, darker region. Border of scales and subjacent skin replete with brown chromatophores, more concentrated at short distance from scale border conferring re- ticulate pattern to body sides, mainly on upper half. Brown chromatophores scattered through whole body, more concentrated on dorsal portion, mainly on head, snout, opercle, and ventral surface of mandible. Ocellated lateral spot rounded or roundish encircled by light ring. Vertical bars along flanks inconspicuous or absent. Dorsal-fin membrane bearing faint band of brown chromatophores on distal border of dorsal fin. Faint band of chromatophores near dorsal-fin base. Pectoral, pelvic, and caudal fins hyaline. Dark brown line along R3. Anal fin of females hyaline; few chromatophores scattered through first three rays but not forming defined patch of pigmentation.

Etymology. The specific epithet leticiae (n. f. gen. sg.) comes from Letícia. Phalloceros leticiae is named after my daughter Letícia M. Lucinda.

Distribution. Phalloceros leticiae is known from the upper rio Araguaia, main tributary to the rio Tocantins (Fig. 7).

Table 2. Descriptive morphometrics of male specimens of Phalloceros leptokeras, P. leticiae, $P$. megapolos, and $P$. mikrommatos. Measurements 1-10 are percents of standard length and measurements 11-13 are percents of head length. $\mathrm{H}=$ holotype.

\begin{tabular}{|c|c|c|c|c|c|c|c|c|c|c|c|c|}
\hline \multirow[t]{2}{*}{ Character } & \multicolumn{3}{|c|}{$\begin{array}{l}\text { Phalloceros leptokeras } \\
\qquad \mathrm{n}=10\end{array}$} & \multicolumn{3}{|c|}{$\begin{array}{c}\text { Phalloceros leticiae } \\
\mathrm{n}=3\end{array}$} & \multicolumn{3}{|c|}{$\begin{array}{l}\text { Phalloceros megapolos } \\
\qquad \mathrm{n}=7\end{array}$} & \multicolumn{3}{|c|}{$\begin{array}{c}\text { Phalloceros mikrommatos } \\
\mathrm{n}=8\end{array}$} \\
\hline & $\mathrm{H}$ & Range & Mean & $\mathrm{H}$ & Range & Mean & $\mathrm{H}$ & Range & Mean & $\mathrm{H}$ & Range & Mean \\
\hline Standard length (mm) & 22.3 & $16.5-23.7$ & 20.4 & 16.2 & $15.5-16.6$ & 16.1 & 23.4 & $17.4-23.4$ & 20.8 & 20.4 & $17.4-20.4$ & 18.7 \\
\hline 1-Head length & 19.9 & $18.0-21.0$ & 19.5 & 21.9 & 21.9-24.6 & 23.4 & 20.7 & 20.1-23.1 & 21.5 & 21.7 & 21.7-23.8 & 22.8 \\
\hline 2-Snout-occipital distance & 21.8 & 18.6-23.2 & 21.0 & 19.6 & 19.2-20.2 & 19.7 & 19.8 & 17.8-19.9 & 19.2 & 18.1 & $18.0-21.5$ & 19.2 \\
\hline 3-Predorsal distance & 57.3 & $55.2-58.6$ & 56.7 & 58.2 & $58.2-60.7$ & 59.1 & 59.7 & $55.8-60.2$ & 58.2 & 58.1 & $57.7-59.9$ & 58.4 \\
\hline 4-Dorsal-fin base length & 11.3 & $8.0-12.8$ & 11.4 & 12.2 & $9.7-12.2$ & 10.7 & 10.4 & $9.6-12.4$ & 10.5 & 11.3 & 7.9-11.4 & 10.3 \\
\hline 5-Anal-fin base length & 6.9 & $6.9-10.5$ & 8.1 & 10.4 & $6.0-10.4$ & 7.7 & 8.2 & $6.5-8.2$ & 7.4 & 7.2 & $6.7-9.6$ & 7.8 \\
\hline 6-Body depth & 34.8 & 31.3-36.9 & 33.2 & 34.2 & $31.3-34.2$ & 32.7 & 34.5 & $31.8-35.7$ & 33.4 & 30.4 & 29.3-32.1 & 30.9 \\
\hline 7-Pre-pelvic length & 26.9 & 25.2-29.6 & 27.2 & 29.7 & 29.7-35.1 & 32.7 & 29.7 & $26.8-29.7$ & 28.3 & 33.1 & $30.8-36.0$ & 32.5 \\
\hline 8-Preanal length & 37.2 & $34.9-41.1$ & 37.7 & 39.3 & $39.3-44.8$ & 42.1 & 39.1 & $36.2-39.6$ & 38.2 & 43.2 & $40.5-45.0$ & 43.1 \\
\hline 9-Postanal length & 63.6 & $56.1-63.6$ & 59.3 & 55.8 & $54.2-57.0$ & 55.7 & 57.4 & $57.4-61.3$ & 59.3 & 54.5 & $52.3-57.3$ & 55.3 \\
\hline 10-Caudal peduncle depth & 17.1 & 14.4-17.1 & 16.0 & 15.9 & 15.9-17.2 & 16.6 & 17.1 & $14.0-17.1$ & 15.7 & 15.5 & 15.1-18.8 & 16.4 \\
\hline 11-Snout length & 23.2 & $17.5-24.3$ & 21.9 & 28.8 & $23.2-28.8$ & 25.3 & 29.3 & $21.4-29.3$ & 25.5 & 23.4 & $23.4-28.0$ & 25.6 \\
\hline 12-Orbital diameter & 44.6 & $40.2-51.0$ & 45.6 & 42.1 & $38.5-42.1$ & 40.8 & 38.4 & $36.8-46.5$ & 40.8 & 40.6 & $33.0-45.6$ & 40.1 \\
\hline 13-Postorbital length & 40.5 & $30.9-48.1$ & 39.0 & 36.7 & $36.7-42.8$ & 39.3 & 33.8 & $33.8-40.3$ & 37.5 & 41.5 & $35.4-42.7$ & 39.2 \\
\hline
\end{tabular}




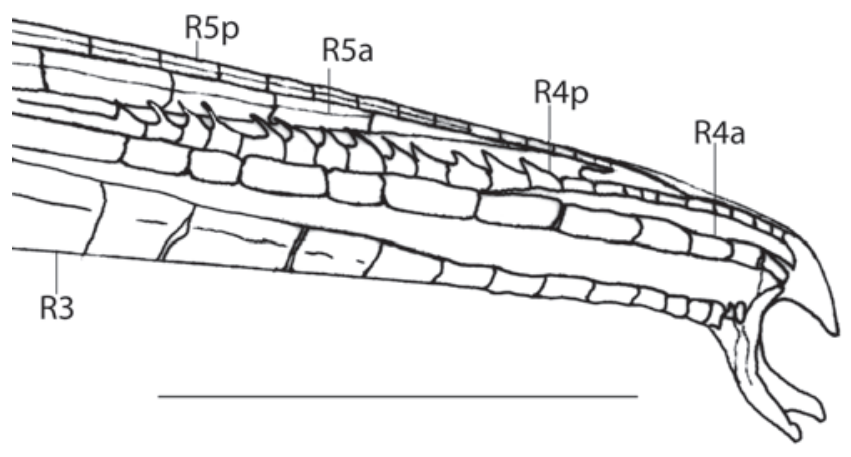

Fig. 6. Gonopodium tip of Phalloceros leticiae, MCP 30551. R3, R4a, R4p, R5a, R5p indicate gonopodial rays. Scale bar $1 \mathrm{~mm}$.

\footnotetext{
Phalloceros heptaktinos $+P$. caudimaculatus $+P$. leptokeras $+P$. aspilos $+P$. tupinamba $+P$. elachistos $+P$. titthos $+P$. enneaktinos $+P$. harpagos $+P$. ocellatus $+P$. alessandrae $+P$. malabarbai $+P$. megapolos $+P$.

lucenorum +P. uai + P. buckupi + P. anisophallos $+P$. pellos + P. spiloura + P. reisi
}

Clade 96, Lucinda \& Reis (2005).

Diagnosis. Members of this clade share the following not uniquely derived and/or reversed features: (1) ascending process of parasphenoids long and contacting pterosphenoids in adults [20-0]; (2) pelvic girdle of males not very anteriorly located; posterior border of basipterygium aligned with posterior border of chleitrum [35-2]; and (3) anterior tip of basipterygium in adult males clearly pointed [37-1].

\section{Phalloceros heptaktinos, new species \\ Figs. 8, 9}

Phalloceros sp. n. A Lucinda \& Reis, 2005.

Holotype. MCP 30406, stream affluent to arroio dos Ratos, at

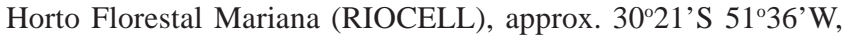

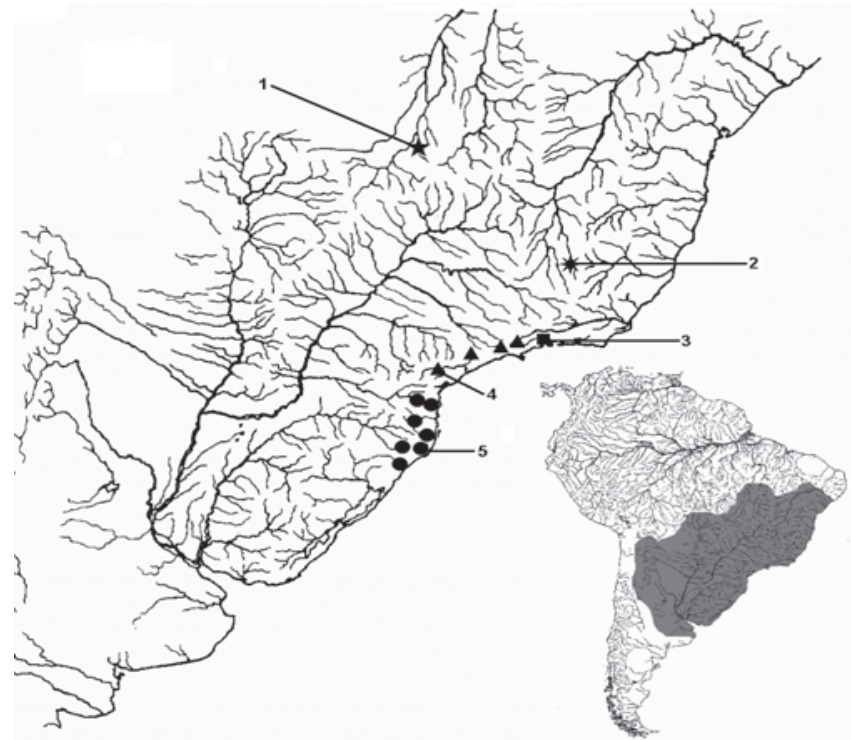

Fig. 7. Collection localities of Phalloceros leticiae (fivepointed star, 1), P. uai (eight-pointed star, 2), P. anisophallos (square, 3), P. reisi (triangle, 4), and P. spiloura (circle, 5). Some symbols represent more than one lot or locality. Numbers represent type localities. The inset is the range of the genus.

Mariana Pimentel, Rio Grande do Sul, Brazil, 23 May 1997, W. Bruschi Jr. \& G. Vinciprova.

Paratypes. BRAZIL. Rio Grande do Sul. MCP 19831, 20/4*, collected with the holotype. MCP 19832, 19, Mariana Pimentel, arroio da Cascata, affluent to arroio dos Ratos, at Horto Florestal Mariana (RIOCELL), 30¹9’7"S 5135’58"W, 22 May 1997, W. Bruschi Jr. \& G. Vinciprova. MCP 26071, 5, same locality and collector of MCP 19831, 1997. MCP 30569, 2, Mariana Pimentel, 19 Jun 2002, F.S. Villela.

Diagnosis. Phalloceros heptaktinos can be distinguished from its congeners by the absence of the basal process of first gonactinost [69-0]. Additionally, P. heptaktinos can be distinguished from its congeners by the sexual dimorphism on number of dorsal-fin rays: males with eight rays (very

Table 3. Descriptive morphometrics of female specimens of Phalloceros heptaktinos, P. malabarbai, P. buckupi, and $P$. lucenorum. Measurements 1-10 are percents of standard length and measurements 11-13 are percents of head length.

\begin{tabular}{|c|c|c|c|c|c|c|c|c|}
\hline \multirow[t]{2}{*}{ Character } & \multicolumn{2}{|c|}{$\begin{array}{l}\text { Phalloceros heptaktinos } \\
\mathrm{n}=14\end{array}$} & \multicolumn{2}{|c|}{$\begin{array}{l}\text { Phalloceros malabarbai } \\
\mathrm{n}=2\end{array}$} & \multicolumn{2}{|c|}{$\begin{array}{c}\text { Phalloceros buckupi } \\
\mathrm{n}=5\end{array}$} & \multicolumn{2}{|c|}{$\begin{array}{c}\text { Phalloceros lucenorum } \\
\mathrm{n}=16\end{array}$} \\
\hline & Range & Mean & Range & Mean & Range & Mean & Range & Mean \\
\hline Standard length (mm) & $19.6-30.3$ & 23.6 & $31.4-32.1$ & 31.8 & $21.7-32.9$ & 28.4 & $26.9-37.0$ & 31.9 \\
\hline 1-Head length & $21.1-23.3$ & 22.3 & $21.3-21.3$ & 21.3 & $21.3-23.7$ & 22.4 & $18.8-24.0$ & 21.6 \\
\hline 2-Snout-occipital distance & $20.9-24.7$ & 22.2 & $22.5-23.1$ & 22.8 & $18.7-20.4$ & 19.4 & $17.5-20.1$ & 18.9 \\
\hline 3-Predorsal distance & $58.7-62.7$ & 61.2 & $62.6-62.8$ & 62.7 & $61.7-64.0$ & 63.0 & $61.8-68.0$ & 64.1 \\
\hline 4-Dorsal-fin base length & $8.2-12.3$ & 10.0 & $10.3-10.8$ & 10.5 & $9.0-10.1$ & 9.3 & $9.0-12.1$ & 10.3 \\
\hline 5-Anal-fin base length & $7.8-11.5$ & 9.7 & $10.2-11.8$ & 11.0 & $9.2-10.8$ & 9.9 & $7.9-10.5$ & 9.0 \\
\hline 6-Body depth & $21.4-26.2$ & 23.3 & $27.2-28.4$ & 27.8 & $23.7-26.7$ & 25.5 & $25.5-29.5$ & 27.3 \\
\hline 7-Pre-pelvic length & $41.3-44.1$ & 42.7 & $40.9-42.7$ & 41.8 & $43.7-46.2$ & 45.3 & $42.6-46.6$ & 44.1 \\
\hline 8-Preanal length & $57.0-59.6$ & 58.1 & $55.2-57.1$ & 56.2 & $56.3-58.9$ & 57.8 & $56.1-60.3$ & 58.1 \\
\hline 9-Postanal length & $33.0-37.5$ & 35.2 & $35.5-36.3$ & 35.9 & $34.5-36.8$ & 36.0 & $34.7-38.1$ & 36.3 \\
\hline 10-Caudal peduncle depth & $13.6-16.1$ & 14.9 & $16.0-16.3$ & 16.2 & $14.7-16.2$ & 15.3 & $14.5-17.4$ & 16.1 \\
\hline 11-Snout length & $17.4-22.7$ & 20.7 & $17.4-22.0$ & 19.7 & $25.2-27.3$ & 26.3 & $19.4-29.3$ & 24.3 \\
\hline 12-Orbital diameter & $35.6-43.2$ & 39.5 & $38.2-40.7$ & 39.4 & $35.7-45.4$ & 40.0 & $27.7-40.8$ & 35.5 \\
\hline 13-Postorbital length & $42.8-51.5$ & 48.1 & $46.9-49.8$ & 48.3 & $32.4-39.8$ & 36.4 & $39.8-44.9$ & 42.3 \\
\hline
\end{tabular}




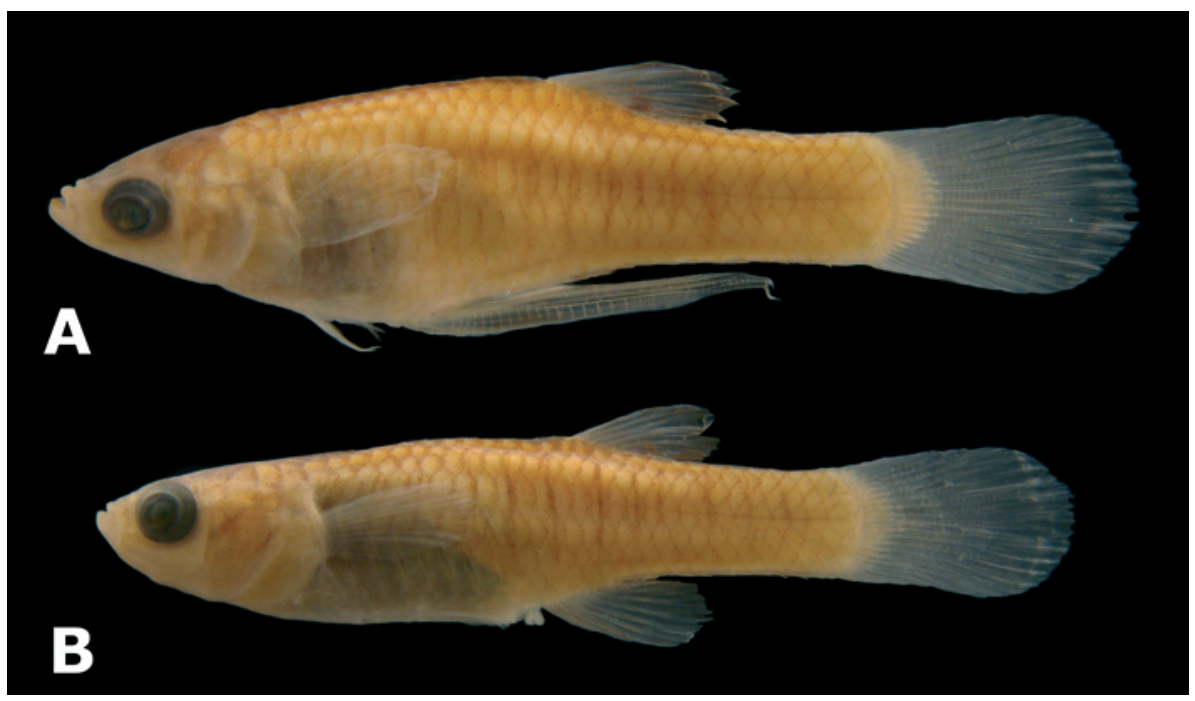

Fig. 8. Phalloceros heptaktinos. (A) Holotype, male, $24.0 \mathrm{~mm}$ SL, MCP 30406, stream affluent to arroio dos Ratos, Mariana Pimentel, Rio Grande do Sul, Brazil; (B) paratype, female, MCP 19831, 23.6 mm SL, collected with the holotype.

exceptionally seven) and females with seven rays (very exceptionally eight).

Description. Morphometric data in Tables 3 and 4. Range of SL: 19.6 to $30.3 \mathrm{~mm}$ (females), 17.1 to $24.0 \mathrm{~mm}$ (males). Dorsalfin rays: 7 [4], 8* [27] (males); 7 [19], 8 [1] (females). Branched pectoral-fin rays: 6 [2], 7 [18], 8* [6]. Pelvic-fin rays: 5* [14] (males), 5 [22] (females). Anal-fin rays of females: 10 [12], 11 [2]. Anal-fin rays of males: 9* [13], 10 [2]. Branched caudal-fin rays: 11 [1], 12* [6], 13 [18], 14 [1]. Predorsal scales: 14* [24]. Longitudinal series of scales: 27 [1], 28* [27], 29 [2]. Series of scales around caudal peduncle: $16^{*}$ [30]. Transverse series of scales: $7^{*}$ [30]. Serrae on R4p: 12 [4], 13 [4], 14 [3], 15 [1], 16* [2]. Epipleural ribs: 10 [1], 11 [3]. Pleural ribs: 13 [4]. Vertebrae: 31 [1], 32 [3]. Female urogenital papilla straight along midline, located along midventral line and between anus and base of first anal-fin ray. Hooks of gonopodial appendix absent (Fig. 9). Sexual dimorphism on number of dorsal-fin rays.

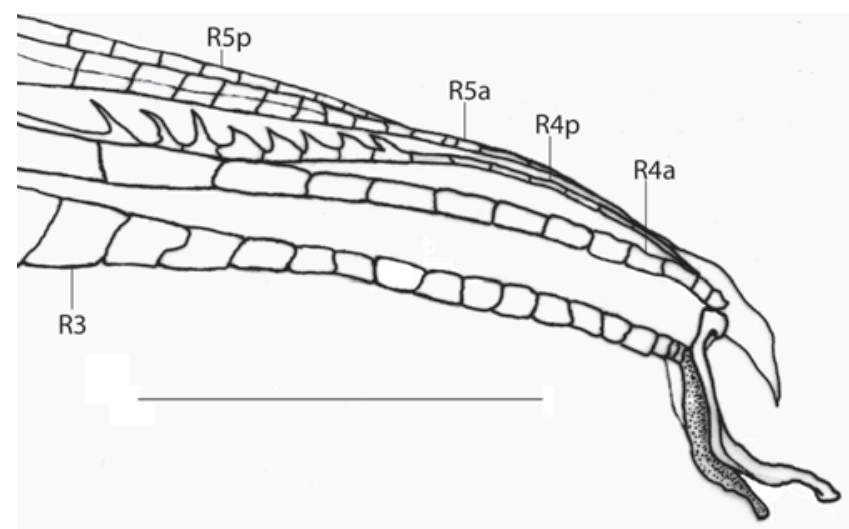

Fig. 9. Gonopodium tip of Phalloceros heptaktinos, MCP 19831. R3, R4a, R4p, R5a, R5p indicate gonopodial rays. Scale bar $1 \mathrm{~mm}$.

Table 4. Descriptive morphometrics of male specimens of Phalloceros heptaktinos, P. malabarbai, P. buckupi, and P. lucenorum. Measurements 1-10 are percents of standard length and measurements 11-13 are percents of head length. $\mathrm{H}=$ holotype.

\begin{tabular}{|c|c|c|c|c|c|c|c|c|c|c|}
\hline \multirow{3}{*}{ Character } & \multicolumn{3}{|c|}{ Phalloceros heptaktinos } & \multirow{3}{*}{$\begin{array}{c}\begin{array}{c}\text { Phalloceros } \\
\text { malabarbai }\end{array} \\
\mathrm{n}=1 \\
\mathrm{H}\end{array}$} & \multicolumn{3}{|c|}{ Phalloceros buckupi } & \multicolumn{3}{|c|}{ Phalloceros lucenorum } \\
\hline & & $\mathrm{n}=16$ & & & & $n=4$ & & & $\mathrm{n}=26$ & \\
\hline & $\mathrm{H}$ & Range & Mean & & $\mathrm{H}$ & Range & Mean & $\mathrm{H}$ & Range & Mean \\
\hline Standard length (mm) & 24.0 & $17.1-24.0$ & 20.5 & 34.1 & 19.3 & $17.8-19.9$ & 18.9 & 26.1 & $18.5-28.0$ & 21.6 \\
\hline 1-Head length & 20.5 & $18.7-21.7$ & 20.6 & 22.2 & 21.0 & $20.4-23.2$ & 21.9 & 22.4 & $19.9-24.4$ & 22.0 \\
\hline 2-Snout-occipital distance & 20.6 & $20.6-22.6$ & 21.6 & 22.3 & 20.9 & $15.9-22.2$ & 19.5 & 18.3 & $16.1-20.4$ & 18.5 \\
\hline 3-Predorsal distance & 60.1 & $56.7-60.1$ & 58.6 & 58.4 & 58.2 & $56.1-61.8$ & 58.4 & 58.3 & $56.5-62.8$ & 59.2 \\
\hline 4-Dorsal-fin base length & 11.5 & $8.1-13.3$ & 11.1 & 12.0 & 11.1 & $11.1-12.7$ & 11.7 & 11.9 & 8.6-13.1 & 11.1 \\
\hline 5-Anal-fin base length & 9.2 & $6.4-10.4$ & 8.4 & 9.6 & 5.6 & $5.6-7.9$ & 6.6 & 7.1 & $5.1-9.7$ & 7.4 \\
\hline 6-Body depth & 34.6 & $31.2-34.9$ & 33.4 & 33.4 & 31.6 & $31.0-33.0$ & 31.7 & 34.4 & $31.1-36.2$ & 34.0 \\
\hline 7-Pre-pelvic length & 31.0 & $28.2-31.0$ & 29.8 & 26.3 & 31.1 & $28.1-35.4$ & 31.0 & 29.5 & $27.8-31.7$ & 29.5 \\
\hline 8-Preanal length & 44.2 & $39.5-44.2$ & 41.5 & 33.2 & 40.3 & $36.8-42.3$ & 39.6 & 40.0 & $37.3-41.3$ & 39.8 \\
\hline 9-Postanal length & 52.4 & $51.7-58.0$ & 55.1 & 60.2 & 58.3 & $55.5-58.9$ & 57.7 & 58.8 & 55.9-59.6 & 57.7 \\
\hline 10-Caudal peduncle depth & 16.0 & $14.4-17.2$ & 15.9 & 15.7 & 16.8 & $14.3-16.8$ & 15.6 & 17.4 & $15.4-17.9$ & 16.6 \\
\hline 11-Snout length & 17.7 & $17.7-24.8$ & 21.8 & 20.2 & 23.2 & $21.7-25.1$ & 22.9 & 24.7 & 21.4-33.4 & 26.8 \\
\hline 12-Orbital diameter & 45.2 & $41.4-46.8$ & 44.0 & 43.0 & 46.3 & $44.6-50.7$ & 47.0 & 36.3 & $36.2-45.3$ & 39.9 \\
\hline 13-Postorbital length & 48.5 & $38.1-48.5$ & 44.0 & 43.3 & 33.0 & $29.6-37.2$ & 33.8 & 41.6 & $32.0-45.2$ & 38.2 \\
\hline
\end{tabular}




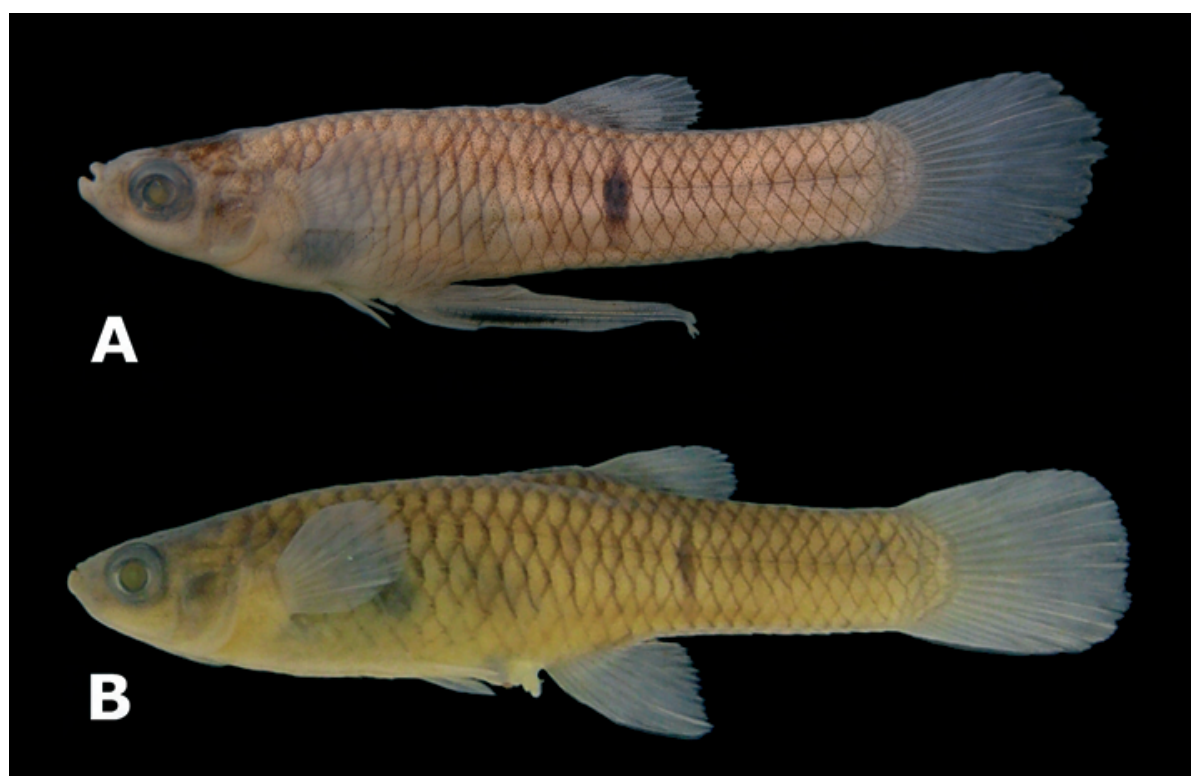

Fig. 10. Phalloceros caudimaculatus, MCP 20158, arroio Feitoria, Sapiranga, Rio Grande do Sul, Brazil. (A) Male, 24.5 mm SL; (B) female, $36.8 \mathrm{~mm} \mathrm{SL}$.

Color in alcohol. Eye black with greenish brown pupil. Ground color cream, darker in upper half. Border of scales and subjacent skin replete with brown chromatophores, more concentrated at short distance from scale border, forming vband conferring reticulate pattern to body sides, mainly on upper half. Brown chromatophores scattered through whole body, more concentrated on dorsal portion, mainly on head, snout, opercle, and ventral surface of mandible. Lateral spot absent. Vertical bars along flanks inconspicuous or absent. Dorsal-fin membrane bearing dark band of chromatophores on distal border of dorsal fin. Dark band of chromatophores near dorsal-fin base, more intense in posterior rays. Pectoral, pelvic, and caudal fins hyaline. Dark brown line along R3. Anal fin of females hyaline, except for patch of dark chromatophores on first three rays and another on last two branched anal-fin rays.

Etymology. From the Greek $\varepsilon \pi \tau \alpha$ [= heptá] (num., i. f.), meaning seven, and $\alpha \kappa \tau \iota v o \varsigma$ [= aktinos] (n. f. nom. pl.), meaning rays, alluding to the number of dorsal-fin rays of females. A noun in apposition.

Distribution. Phalloceros heptaktinos is only known from tributaries of the arroio dos Ratos, Jacuí basin, in Mariana Pimentel, Rio Grande do Sul. Phalloceros heptaktinos is sympatric with $P$. caudimaculatus (Fig. 4).

Phalloceros caudimaculatus + P. leptokeras + P. aspilos + P. tupinamba + P. elachistos $+P$. titthos $+P$. enneaktinos + $P$. harpagos $+P$. ocellatus $+P$. alessandrae +

P. malabarbai + P. megapolos + P. lucenorum + P. uai + P. buckupi + P. anisophallos + P. pellos + P. spiloura + P. reisi

Clade 89, Lucinda \& Reis (2005)
Diagnosis. Members of this clade share the following not uniquely derived and/or reversed feature: elliptical spot on median region of flanks [134-2].

\section{Phalloceros caudimaculatus (Hensel, 1868) \\ Figs. 10, 11}

Girardinus caudimaculatus Hensel, 1868: 362. Type-locality: an der Costa da Serra bei S. Leopoldo in Brunnen und Gräben [ $=$ at the Costa da Serra at São Leopoldo in pounds and ditches].

Type-material. ZMB 7425, lectotype [by present designation], Costa de Sierra [sic], Hensel. ZMB 7426, 5, paralectotypes [not examined], Costa da Serra at S. Leopoldo, (Hensel ?). ZMB 31496 (13 of 25 females), paralectotypes, “C. da Serra,... ? [illegible] bei S. Leopolds” [sic]. ZMB 33220, 1, paralectotype, collected with the lectotype.

Material Examined. Laguna dos Patos System. BRAZIL. Santa Catarina. MCP 22337, 6, Bom Jardim da Serra, rio Barrinha at Bom Jardim da Serra, way-out to Santa Bárbara, 28²0’15"S 49³7’49"W. Rio Grande do Sul. MCP 9305, 11, Pantano Grande, arroio Dom Marcos, 30¹3’32"S 52³7’9"W. MCP 9539, 3, Cachoeira do Sul. MCP 10060, 1, Três Coroas, arroio Moreira, Distrito de Sander. MCP 10285, 14, Canoas, Distrito de Mato Grande, stream affluent to rio dos Sinos. MCP 10750, 5, Arroio dos Ratos, near BR 290. MCP 11356, 6, arroio Xasqueiro, near road BR 116 between Pelotas and Jaguarão. MCP 11557, 2, Gramado, arroio Linha Bonita. MCP 17249, 65, São Sepé. MCP 17385, 6, Minas do Leão, arroio Taquara under bridge on road BR 290, near Minas do Leão. MCP 17578, 29, Pelotas, arroio Totó, road to Colônia Z-3. MCP 18249, 18, Faxinal do Soturno, creek near road Faxinal do Soturno to Ivorá. MCP 19104, 2, Barra do Ribeiro. MCP 19698, 2, Encruzilhada do Sul, arroio Passo da Miséria, between Encruzilhada do Sul and Canguçu. MCP 20158, 16/4*, Sapiranga, arroio Feitoria. MCP 20837, 16, Pedro Osório, arroio Reduzinho, between Pedro Osório and Basílio, 3154’25"S 5255’41"W. MCP 21251, 29, Segredo, wetland at Três 
Vendas on road from Bela Vista to Coloninha, 29¹5’32"S 5353’34"W. MCP 21355, 68, Tavares, stream at Balneário de Bujuru, 3140’18"S 51²4’27"W. MCP 21355, 68, Viamão, stream at Praia da Pedreira, Parque Estadual de Itapuã, 30²1’30"S 51²’48"W. MCP 21515, 1, arroio Formoso and lateral ponds, $\mathrm{ca} .7 .8 \mathrm{~km} \mathrm{~N}$ from Dona Francisca, 29³3’49"S 5320'59"W. MCP 22338, 22, Lageado Grande, arroio Lageado Grande, near road to Jaquirana, 295’34"S 50³7’30"W. MCP 23666, 25, Santa Maria, wetland ca. 500 m from rio Vacacaí. MCP 23883, 14, São Lourenço do Sul, stream affluent to arroio Grande between Colônia de Santana and road BR 116, 31²2’38"S 527'37"W. MCP 23884, 7, Tapes, arroio Teixeira and lateral pond on road BR 116, 30³7’26"S 51³2’45"W. MCP 25755, 49, Camaquã, arroio Maria Ulghim, at road from Camaquã to Vila Aurora. MCP 25784, 1, Caçapava do Sul, arroio do Banhado on road BR $153 \mathrm{ca} .8 \mathrm{~km}$ NW of Minas do Camaquã, 3051’48"S 53²9’50"W. MCP 25874, 24, creek affluent to arroio Correio, between Caçapava do Sul and Lavras do Sul, 3043’15"S 5340’53"W. MCP 25899, 2, Lavras do Sul, stream affluent to arroio Camaquã Chico, 3059'6"S 5358'20"W. MCP 26051, 2, Dois Irmãos, arroio Feitoria at Picada Verão, 29³4'37"S 5113'"W. MCP 26126, 24, Santa Maria Herval, arroio Cadeia, affluent to rio Caí, at Prainha do Jacaré. MCP 27298, 2, Candiota, arroio Candiota, Passo do Cerro, near confluence with rio Jaguarão, 3149’57"S 5351’19"W. MCP 29254, 61, São Francisco de Paula, arroio Lava-pés, affluent to rio Caí ca. 20 km from road RS 235. MCP 30889, 9, Canela, arroio Caçador, tributary to rio Caí, 29¹8’50"S 5047'15"W. UFRGS 2728, 98, Rio Grande, km 115 of road BR 471. Estaçäo Ecológica do Taim. URUGUAY. Rocha. ZVC-P 3209, 9, Ruta 14, km 498, bañado de los Índios, Laguna Negra - Laguna Merín drainage. ZVC-P 3229, 2, Ruta 14, km 457, Río San Luis - Laguna Merín. ZVC-P 4006, 3, Ruta 15, km 179, Laguna Merín. Rio Ibicuí drainage: BRAZIL. Rio Grande do Sul. MCP 9490, 6, Cacequi, stream near road from Cacequi to São Francisco de Assis, Vila Itapevi. MCP 14136, 10, Dom Pedrito. MCP 23081, 2, São Francisco de Assis, rio Inhacundá at São Francisco de Assis exit to Manuel Viana, 29³2’51"S 558'11"W. MCP 26746, 9, Santana do Livramento, arroio Ibicuí da Faxina near BR 158, 304'31"S 5512’35"W. Rio Negro drainage: BRAZIL. Rio Grande do Sul. MCP 22880, 27, rio Paraizinho on road from Bagé to BR 293, ca. 1 km S of BR 293. URUGUAY. Cerro Largo. MCP 10394, 10, Arreria, Río Negro, hacienda Arreria. Colonia. ZVC-P 676, 5, Carmelo, Río Uruguay. Durazno. ZVC-P 3324, 3, lateral laguna, Arroyo Cordobés, affluent to Río Yí, affluent to Río Negro. ZVC-P 3400, 1, 3 km NW from Estación de AFE, paraje 329, nearby mouth of Río Tacuarembó on Río Negro. Rio Mampituba drainage: BRAZIL. Santa Catarina. MCP 29267, 90, Praia Grande, arroio Moia Coco at Vila Rosa ca. $5 \mathrm{~km}$ NW from Praia Grande, 29¹0’27"S 4958’26"W. Rio Grande do Sul. MCP 14840, 34, Três Cachoeiras, rio das Pacas, near Morro Azul. MCP 23731, 4, Mampituba, rio Panela. Rio Tramandaí drainage: BRAZIL. Rio Grande do Sul. MCP 10801, 5, Osório, rio Maquiné. MCP 20291, 27, Torres, creek on dunes. MCP 25294, 30, Terra de Areia, rio Três Pinheiros, under bridge on road to Vila Itati, ca. $7 \mathrm{~km} \mathrm{~N}$ from road BR 101. MCP 25385, 7, Maquiné, arroio Água Parada. MCP 29283, 5, Itati, stream on road between "Rota do Sol” (RS 486) and Vila Itati, 29²9'22"S 506’20"W. UFRGS 4456, 20, Tramandaí. USNM 297952, 1, rio Sanga Funda, crossing BR 101 road just S of Terra de Areia. Laguna Castillos drainage: URUGUAY. Rocha. ZVC-P 3237, 8, bridge at Arroyo Valizas, Laguna Castillos. ZVC-P 3248, 21, pond alongside secondary road between Balneario Aguas Dulces and Ruta 10, Laguna Castillos. Argentinean coastal drainage: Buenos Aires. AMNH 93354, 54, Punta Lara, just N of La Plata, in roadside ditches.

Diagnosis. Phalloceros caudimaculatus can be distinguished from $P$. anisophallos, $P$. megapolos, $P$. spiloura, $P$. reisi, $P$. buckupi, P. alessandrae, P. lucenorum, P. uai, P. pellos, and $P$. malabarbai by the female urogenital papilla straight along midline and located between the anus and the base of first anal-fin ray (vs. curved to the right, located laterally; border of the anal aperture in contact with the first anal-fin ray). Phalloceros caudimaculatus can be distinguished from $P$. tupinamba, $P$. leptokeras, and $P$. aspilos by (1) the female urogenital papilla straight along midline (vs. slightly left turned); (2) absence of a lateral ramus of the female urogenital papilla (vs. lateral ramus present); and (3) absence of hook in gonopodial appendix (vs. hook present). Phalloceros caudimaculatus can be distinguished from $P$. enneaktinos, $P$. titthos, $P$. elachistos, and $P$. harpagos by the absence of hooks in both halves of the gonopodial appendix (vs. hook present in both halves). Phalloceros. caudimaculatus is readily distinguished from $P$. heptaktinos by the absence of sexual dimorphism on number of dorsal-fin rays: males with 8 rays (very exceptionally seven) and females with seven rays (very excep-

Table 5. Descriptive morphometrics of female specimens of Phalloceros caudimaculatus, P. anisophallos, P. alessandrae, and $P$. aspilos. Measurements 1-10 are percents of standard length and measurements 11-13 are percents of head length.

\begin{tabular}{|c|c|c|c|c|c|c|c|c|}
\hline \multirow[t]{2}{*}{ Character } & \multicolumn{2}{|c|}{$\begin{array}{c}\text { Phalloceros } \\
\text { caudimaculatus } \\
\mathrm{n}=158\end{array}$} & \multicolumn{2}{|c|}{$\begin{array}{c}\text { Phalloceros } \\
\text { anisophallos } \\
\mathrm{n}=28\end{array}$} & \multicolumn{2}{|c|}{$\begin{array}{c}\text { Phalloceros alessandrae } \\
\mathrm{n}=2\end{array}$} & \multicolumn{2}{|c|}{$\begin{array}{c}\text { Phalloceros aspilos } \\
\mathrm{n}=13\end{array}$} \\
\hline & Range & Mean & Range & Mean & Range & Mean & Range & Mean \\
\hline Standard length (mm) & $18.9-45.0$ & 28.2 & $21.9-45.1$ & 34.0 & $22.1-24.7$ & 23.4 & $25.8-38.3$ & 34.2 \\
\hline 1-Head length & $16.8-24.8$ & 21.5 & $18.1-26.2$ & 21.6 & $22.1-25.2$ & 23.6 & $17.6-20.8$ & 19.0 \\
\hline 2-Snout-occipital distance & 18.9-26.2 & 22.4 & $16.2-22.6$ & 18.6 & 19.6-19.9 & 19.8 & $18.0-22.1$ & 20.1 \\
\hline 3-Predorsal distance & $58.0-66.3$ & 62.1 & $60.7-65.2$ & 63.2 & $63.6-64.3$ & 63.9 & $58.4-63.2$ & 60.8 \\
\hline 4-Dorsal-fin base length & 7.8-13.9 & 10.3 & 8.8-11.9 & 10.2 & $9.6-10.8$ & 10.2 & $9.3-12.8$ & 10.6 \\
\hline 5-Anal-fin base length & $6.7-14.4$ & 9.6 & $6.7-10.7$ & 9.3 & $7.7-10.2$ & 8.9 & $8.4-11.0$ & 10.0 \\
\hline 6-Body depth & 21.3-28.9 & 25.6 & $21.9-28.2$ & 25.8 & $21.4-24.8$ & 23.1 & $23.0-26.1$ & 24.9 \\
\hline 7-Pre-pelvic length & $40.3-50.0$ & 43.5 & 42.6-47.9 & 45.4 & $44.9-45.8$ & 45.4 & $40.1-44.5$ & 42.3 \\
\hline 8-Preanal length & 54.6-64.7 & 58.0 & $56.7-60.1$ & 58.8 & $57.2-58.3$ & 57.8 & $55.0-59.7$ & 56.9 \\
\hline 9-Postanal length & $31.0-39.9$ & 36.0 & 33.2-38.9 & 35.7 & $35.5-35.8$ & 35.6 & $35.0-39.3$ & 37.0 \\
\hline 10-Caudal peduncle depth & 13.7-17.6 & 15.4 & 14.2-16.9 & 15.8 & 14.1-14.4 & 14.3 & $13.0-14.8$ & 14.0 \\
\hline 11-Snout length & $14.6-27.7$ & 21.3 & 20.1-31.5 & 25.3 & $25.1-28.3$ & 26.7 & $17.6-25.9$ & 21.3 \\
\hline 12-Orbital diameter & $32.7-47.0$ & 39.0 & $31.5-43.6$ & 37.0 & $38.0-40.2$ & 39.1 & $34.0-45.2$ & 39.5 \\
\hline 13-Postorbital length & $38.7-56.3$ & 47.2 & $33.4-47.2$ & 40.1 & $35.3-40.9$ & 38.1 & $42.7-52.2$ & 46.0 \\
\hline
\end{tabular}


tionally 8). Phalloceros caudimaculatus can be distinguished from P. ocellatus, P. mikrommatos, and P. leticiae by the lateral spot: $P$. caudimaculatus possesses a non-ocellated elliptical and vertically elongate lateral spot (rarely absent), whereas $P$. ocellatus, $P$. mikrommatos, and P. leticiae possess roundish to rounded and well-defined ocellated lateral spot.

Description. Morphometric data in Tables 5 and 6. Range of SL: 18.9 to $45.0 \mathrm{~mm}$ (females), 14.3 to $28.8 \mathrm{~mm}$ (males). Dorsalfin rays: 7 [3], 8 [266*], 9 [6]. Branched pectoral-fin rays: 5 [2], 6 [76], 7 [121], 8 [5] (types total number: 10 [6], 11 [5] ). Pelvicfin rays: 4 [1], 5 [83] (males), 4 [1], 5 [185] (females). Anal-fin rays of females: 10 [23], 11* [156]. Anal-fin rays of males: 8 [3], 9 [91], 10 [7]. Branched caudal-fin rays: 10 [6], 11* [68], 12 [135], 13 [30], 14 [11]. Predorsal scales: 12 [3], 13 [23], $14 *[159]$, 15* [6]. Longitudinal series of scales: 27 [28], 28 [141], 29* [104], 30 [12], 31 [2]. Series of scales around caudal peduncle: 16* [296]. Transverse series of scales: 6 [1], $7 *$ [297]. Serrae on R4p: 8[1],9 [9], 10 [30], 11 [31], 12 [23], 13* [16], 15 [2]. Epipleural ribs: 10 [1], 12 [2], 13 [1]. Pleural ribs: 14 [4]. Vertebrae: 33 [4]. Female urogenital papilla straight along midline, located along midventral line and between anus and base of first anal-fin ray. Hooks of gonopodial appendix absent (Fig. 11).

Color in alcohol. Eye black with greenish brown pupil. Ground color pale brown, darker in upper half. Border of scales and subjacent skin replete with brown chromatophores, more concentrated at short distance from scale border, forming $\mathrm{v}$-band conferring reticulate pattern to body sides, mainly on upper half. Brown chromatophores scattered through whole body, more concentrated on dorsal portion, mainly on head, snout, opercle, and ventral surface of mandible. Lateral dark brown spot located on $14^{\text {th }}, 15^{\text {th }}$, and $16^{\text {th }}$ or $16^{\text {th }}, 17^{\text {th }}$, and $18^{\text {th }}$ scale of longitudinal series. Lateral spot covering approximately one and half scale on horizontal direction, and four or five scales on vertical, sometimes reaching dorsal and ventral profiles. Dorsal-fin membrane bearing dark band of chromatophores

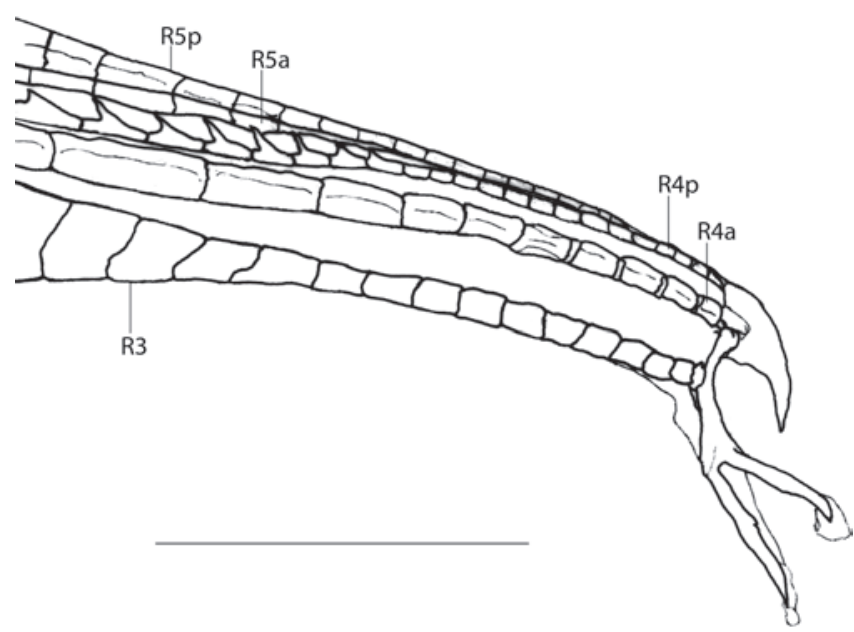

Fig. 11. Gonopodium tip of Phalloceros caudimaculatus, MCP 20158. R3, R4a, R4p, R5a, R5p indicate gonopodial rays. Scale bar $1 \mathrm{~mm}$.

on distal border of dorsal fin. Dark band of chromatophores near dorsal-fin base, more intense in posterior rays. Pectoral, pelvic, and caudal fins hyaline. Dark brown line along R3. Anal fin of females hyaline, except for patch of dark chromatophores on first three rays.

Geographical variation. Color pattern of $P$. caudimaculatus varies considerably. The lateral spot is very frequently present, however, it may be absent. When present the lateral spot cover one to six transverse series of scales and less than one to three scales of the longitudinal series. Similarly lateral dark bars varies from inconspicuous to visible. It was not possible to correlate the color pattern to any geographical population for it varies among the specimens of the same population.

Distribution. Laguna dos Patos system, lower portions of rio Uruguai, rio Tramandaí drainage, rio Mampituba drainage and coastal drainages of Uruguay and Argentina (Fig. 12).

Table 6. Descriptive morphometrics of male specimens of Phalloceros Phalloceros caudimaculatus, P. anisophallos, $P$. alessandrae, and $P$. aspilos. Measurements 1-10 are percents of standard length and measurements 11-13 are percents of head length. $\mathrm{H}=$ holotype.

\begin{tabular}{|c|c|c|c|c|c|c|c|c|c|}
\hline \multirow{3}{*}{ Character } & \multirow{2}{*}{\multicolumn{2}{|c|}{$\begin{array}{l}\text { Phalloceros caudimaculatus } \\
\qquad \mathrm{n}=64\end{array}$}} & \multirow{2}{*}{\multicolumn{3}{|c|}{$\begin{array}{l}\text { Phalloceros anisophallos } \\
\qquad \mathrm{n}=10\end{array}$}} & \multirow{3}{*}{$\begin{array}{c}\text { Phalloceros } \\
\text { alessandrae } \\
\mathrm{n}=1 \\
\mathrm{H}\end{array}$} & \multirow{2}{*}{\multicolumn{3}{|c|}{$\begin{array}{l}\text { Phalloceros aspilos } \\
\qquad \mathrm{n}=3\end{array}$}} \\
\hline & & & & & & & & & \\
\hline & Range & Mean & $\mathrm{H}$ & Range & Mean & & $\mathrm{H}$ & Range & Mean \\
\hline Standard length (mm) & $14.3-28.8$ & 19.5 & 28.2 & $16.2-28.2$ & 22.7 & 17.5 & 23.6 & $22.2-23.8$ & 23.2 \\
\hline 1-Head length & $16.6-24.4$ & 21.5 & 23.3 & 20.6-25.6 & 22.3 & 23.2 & 20.5 & $19.3-20.5$ & 19.8 \\
\hline 2-Snout-occipital distance & $16.4-25.4$ & 22.3 & 17.9 & $15.7-21.4$ & 18.8 & 20.4 & 21.8 & $20.1-21.8$ & 21.2 \\
\hline 3-Predorsal distance & $55.2-62.1$ & 58.7 & 60.2 & $57.9-60.3$ & 58.9 & 60.9 & 55.7 & $54.8-56.3$ & 55.6 \\
\hline 4-Dorsal-fin base length & $7.5-14.5$ & 10.8 & 11.1 & $8.1-12.3$ & 10.6 & 9.1 & 11.4 & 11.4-13.1 & 12.1 \\
\hline 5-Anal-fin base length & $5.8-10.8$ & 8.0 & 7.9 & $6.5-8.7$ & 7.7 & 8.0 & 6.9 & $6.6-8.0$ & 7.2 \\
\hline 6-Body depth & $30.9-37.4$ & 33.9 & 36.7 & $30.6-36.7$ & 33.5 & 33.0 & 31.8 & $30.8-32.8$ & 31.8 \\
\hline 7-Pre-pelvic length & $27.3-34.9$ & 30.4 & 30.0 & $29.9-32.5$ & 30.7 & 30.9 & 27.6 & $27.3-27.7$ & 27.5 \\
\hline 8-Preanal length & $37.2-45.2$ & 40.8 & 39.1 & $38.3-42.8$ & 40.0 & 40.4 & 39.3 & $38.0-39.7$ & 39.0 \\
\hline 9-Postanal length & $52.8-60.9$ & 56.6 & 58.6 & $54.6-59.3$ & 57.5 & 55.9 & 59.0 & $58.5-59.5$ & 59.0 \\
\hline 10-Caudal peduncle depth & $13.9-18.5$ & 16.1 & 17.8 & $14.6-18.8$ & 16.4 & 15.0 & 15.5 & $14.8-15.5$ & 15.2 \\
\hline 11-Snout length & $16.3-30.2$ & 22.7 & 28.3 & $25.1-31.3$ & 27.9 & 29.0 & 22.8 & $21.1-25.1$ & 23.0 \\
\hline 12-Orbital diameter & $36.2-50.5$ & 41.9 & 32.7 & $32.7-48.1$ & 39.2 & 50.1 & 42.4 & $42.4-46.3$ & 44.0 \\
\hline 13-Postorbital length & $33.6-50.0$ & 43.0 & 42.8 & $29.5-42.8$ & 37.3 & 23.8 & 41.6 & $37.3-42.8$ & 40.6 \\
\hline
\end{tabular}


Remarks. Among the original type series (Hensel, 1868: 362364) only the seven specimens from lots ZMB 7425 and ZMB 7426 are surely syntypes of Girardinus caudimaculatus. It is not absolutely sure, whether the 25 specimens of lot ZMB 31496 belongs to the type series, since this number is secondarily based on an old label from the anatomical collection: “No, 25202, “ Girardinus caudimaculata, C. da Serra ", - the remainder of the label is illegible (Paepke \& Seegers, 1986). This is the collection of the former "Institute of Anatomy of the Humboldt-University" in the 19th century, which used to belong to the Medical Faculty. This is due to the fact that human-anatomists were traditionally doing much research work on comparative anatomy of vertebrates. Thus, collected material was often divided between Zoological (Philosophical) Faculty with the Zoological Collection and the Medical Faculty. Only from approximately 1890 onwards the collections were reunited. But, apparently also R. Virchow, the famous pathologist working at the Charity Hospital at HumboldtUniversity, took over some of the original anatomical collection for study (Peter Bartsch in litt., 2000). As there is no apparent evidence that Hensel has not examined specimens from lot ZMB 31496, it should be more advisable to label them as syntypes. Whether oncoming evidences demonstrate that these specimens have not been syntypes, they will lose their type status.

Reinhold F. Hensel was a German geographer and naturalist who lived in Brazil from 1863 to 1866. He collected in Rio Grande do Sul, especially in Porto Alegre and the German colonies to the north of that city (Papavero, 1973). Further, when Hensel returned to Germany, he published the results

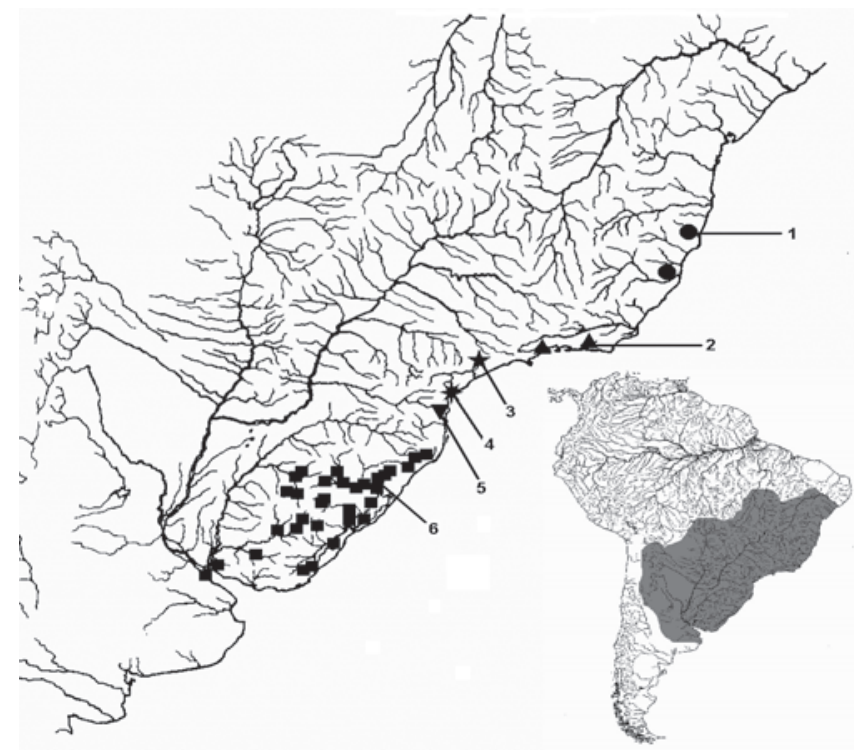

Fig. 12. Collection localities of Phalloceros ocellatus (circle, 1), P. tupinamba (triangle, 2), P. lucenorum (five-pointed star, 3), P. buckupi (eight-pointed star, 4), P. titthos (inverted triangle, 5), and $P$. caudimaculatus (square, 6). Some symbols represent more than one lot or locality. Numbers represent type localities. The inset is the range of the genus. of his works in Brazil. In 1867 he published a large geographical report of the Província of São Pedro do Rio Grande do Sul (presently the Rio Grande do Sul State) including a map of the region (Hensel, 1867). Later, he dealt with descriptions of new vertebrate taxa, including Girardinus caudimaculatus (Hensel, 1868; 1870). The type-locality of G. caudimaculatus is mentioned as "an der Costa da Serra bei S. Leopoldo in Brunnen und Gräben" [ = at the Costa da Serra at São Leopoldo in pounds and ditches]. The 1867 map shows that Costa da Serra corresponds to the area located in the south margin of the rio Cadeia and arroio Feitoria nearby the Encosta da Serra, and is delimited to the south by the rio dos Sinos drainage. This region currently corresponds to portions of the counties of São Sebastião do Caí, Estância Velha, and Ivoti. Although it is not possible to precisely locate the type-locality it seems very probable that Hensel would have collected his syntypes in the drainage of the rio Cadeia.

One of 26 specimens of USNM 309769, is not $P$. caudimaculatus (is $P$. harpagos). The overall coloration of this individual is different from the remaining and $P$. harpagos is not sympatric with $P$. caudimaculatus. This specimen likely came from another lot by mistake.

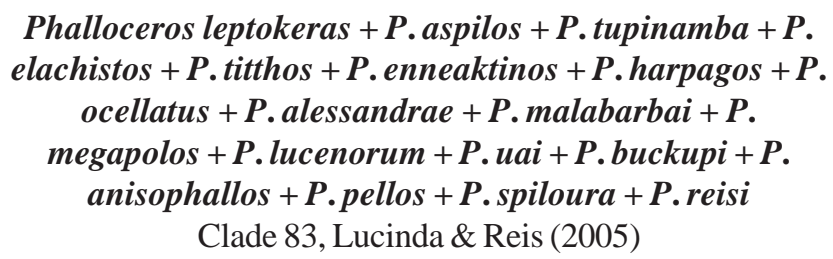

Diagnosis. Members of this clade share the following uniquely derived reversed hooks present in both halves of gonopodial paired appendix [98-1*].

\section{Phalloceros tupinamba + P. aspilos + P. leptokeras Clade 81, Lucinda \& Reis (2005).}

Table 7. Descriptive morphometrics of female specimens of Phalloceros tupinamba and P. uai. Measurements 1-10 are percents of standard length and measurements 11-13 are percents of head length.

\begin{tabular}{lcccc}
\hline \multicolumn{1}{c}{ Character } & \multicolumn{2}{c}{$\begin{array}{c}\text { Phalloceros } \\
\text { tupinamba }\end{array}$} & \multicolumn{2}{c}{ Phalloceros uai } \\
& $\begin{array}{c}c \\
\mathrm{n}=30\end{array}$ & \multicolumn{2}{c}{$\mathrm{n}=12$} \\
& Range & Mean & Range & Mean \\
\hline Standard length (mm) & $22.9-44.0$ & 30.1 & $18.7-33.8$ & 27.4 \\
1-Head length & $17.4-22.9$ & 20.3 & $19.4-24.3$ & 21.3 \\
2-Snout-occipital distance & $17.6-25.6$ & 21.6 & $17.4-20.7$ & 18.9 \\
3-Predorsal distance & $59.4-63.3$ & 61.3 & $60.4-64.8$ & 62.9 \\
4-Dorsal-fin base length & $8.0-12.0$ & 9.9 & $8.4-10.9$ & 9.8 \\
5-Anal-fin base length & $8.6-12.1$ & 10.4 & $8.0-10.1$ & 9.1 \\
6-Body depth & $23.4-27.8$ & 25.9 & $22.6-27.9$ & 24.8 \\
7-Pre-pelvic length & $39.4-44.4$ & 42.0 & $41.9-47.4$ & 43.6 \\
8-Preanal length & $55.2-60.0$ & 57.3 & $56.6-60.1$ & 58.3 \\
9-Postanal length & $33.8-39.5$ & 36.8 & $34.3-37.9$ & 36.3 \\
10-Caudal peduncle depth & $13.6-15.6$ & 14.6 & $14.3-15.7$ & 15.0 \\
11-Snout length & $17.7-27.9$ & 22.5 & $20.6-28.9$ & 25.1 \\
12-Orbital diameter & $33.7-47.1$ & 39.2 & $31.4-38.4$ & 35.9 \\
13-Postorbital length & $37.3-51.3$ & 45.4 & $35.7-46.3$ & 41.9 \\
\hline
\end{tabular}




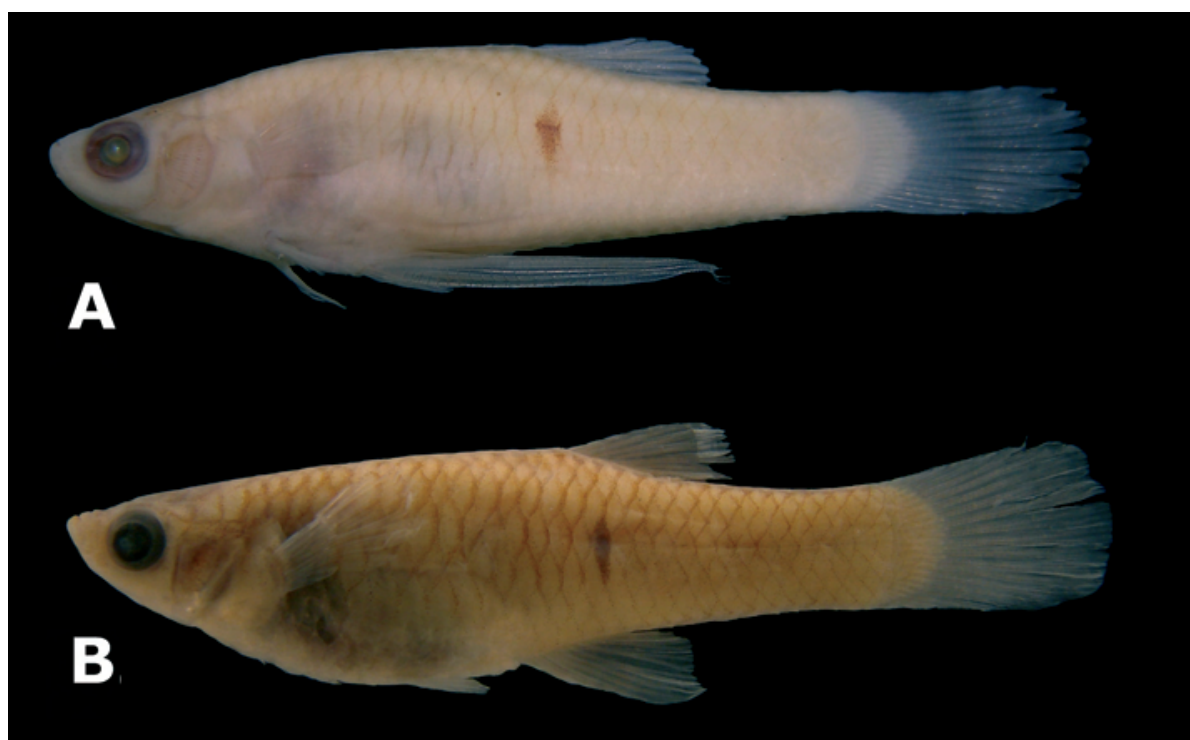

Fig. 13. Phalloceros tupinamba. (A) Holotype, male, 22.4 mm SL, MCP 30408, rio Macacu, Cachoeiras de Macacu, Rio de Janeiro, Brazil; (B) paratype, female, MCP 20585, collected with the holotype.

Diagnosis. Members of this clade share the following uniquely derived and unreversed features: (1) hooks on paired gonopodial appendix large and sickle like [94-1**]; and (2) female urogenital papilla left turned [142-2**].

Additionally, the following not uniquely derived and/or reversed feature can diagnose this clade: halves of gonopodial paired appendix sickle like, lacking a medium corner [96-1].

\section{Phalloceros tupinamba, new species}

Figs. 13, 14

\section{Phalloceros sp. n. E Lucinda \& Reis (2005).}

Holotype. MCP 30408, rio Macacu, ca. $1.5 \mathrm{~km}$ SE from Macacu, near road RJ 116. Cachoeiras de Macacu, Rio de Janeiro, Brazil, 22²9’9"S 42³9’34"W, 19 Jan 1997, J. F. P. Silva et al.

Paratypes. BRAZIL. Rio de Janeiro. MCP 20585, 2*/26, collected with the holotype. São Paulo. MCP 31135, 30, Ubatuba, cachoeira Ipiranguinha $2.4 \mathrm{~km}$ from road SP 125 (affluent to rio Grande), $23^{\circ} 25^{\prime} 40^{\prime \prime S} 45^{\circ} 7^{\prime} 43^{\prime \prime} \mathrm{W}, 17$ Oct 2002, V. A. Bertaco et al. MCP 31346, 150, Ubatuba, Cachoeira dos Macacos on road SP 125 towards Taubaté ca. $4.6 \mathrm{~km}$ from road BR 101 (affluent to rio Grande),

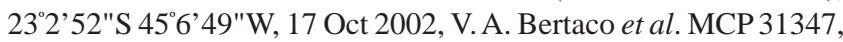
39, Ubatuba, stream near SABESP, ca. $1.2 \mathrm{~km}$ from road BR 101, $23^{\circ} 26^{\prime} 43^{\prime \prime S} 45^{\circ} 05^{\prime} 24 " \mathrm{~W}, 17$ Oct 2002, V. A. Bertaco et al. MCP 31624, 428, São Paulo. Ubatuba, creek on road SP 125 towards

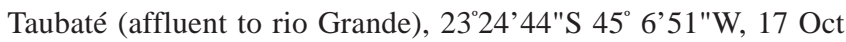
2002, V. A. Bertaco et al. MZUSP 39993, 2, Ubatuba, rio Indaiá, J. Sabino. USNM 257032, 27, rio Itamambuca, upstream of road BR 101, 23²3’40"S 4500’45"W, 29 Oct 1982, N. A. Menezes \& L. Pini Netto.

Diagnosis. Phalloceros tupinamba is readily distinguished from its congeners, except $P$. leptokeras and $P$. aspilos by (1) the presence a lateral ramus of the female urogenital papilla; (2) female urogenital papilla left turned; (3) large sickle like

Table 8. Descriptive morphometrics of male specimens of Phalloceros tupinamba and P. uai. Measurements 1-10 are percents of standard length and measurements 11-13 are percents of head length. $\mathrm{H}=$ holotype.

\begin{tabular}{lcccccc}
\hline \multicolumn{1}{c}{ Character } & \multicolumn{3}{c}{ Phalloceros tupinamba } & \multicolumn{3}{c}{ Phalloceros uai } \\
& $\mathrm{n}$ & $\mathrm{n}=9$ & & \multicolumn{3}{c}{$\mathrm{n}=4$} \\
& $\mathrm{H}$ & Range & Mean & $\mathrm{H}$ & Range & Mean \\
\hline Standard length (mm) & 22.4 & $17.0-27.4$ & 21.9 & 16.6 & $15.3-16.6$ & 16.0 \\
1-Head length & 20.7 & $18.6-21.7$ & 20.6 & 22.4 & $20.9-23.2$ & 22.3 \\
2-Snout-occipital distance & 22.4 & $20.2-22.4$ & 21.4 & 17.7 & $17.7-22.5$ & 20.2 \\
3-Predorsal distance & 57.7 & $57.5-59.8$ & 58.4 & 56.6 & $55.5-58.1$ & 57.1 \\
4-Dorsal-fin base length & 12.7 & $8.4-12.7$ & 11.2 & 9.6 & $9.6-13.9$ & 11.9 \\
5-Anal-fin base length & 8.9 & $7.2-9.8$ & 8.1 & 5.1 & $5.1-9.1$ & 7.5 \\
6-Body depth & 34.0 & $30.3-35.0$ & 33.2 & 31.3 & $29.3-31.3$ & 30.4 \\
7-Pre-pelvic length & 28.9 & $25.7-29.0$ & 28.0 & 28.6 & $28.6-33.2$ & 30.4 \\
8-Preanal length & 39.1 & $37.4-40.9$ & 38.4 & 37.8 & $37.8-41.4$ & 39.8 \\
9-Postanal length & 57.1 & $56.0-59.5$ & 57.5 & 62.0 & $55.2-62.0$ & 57.5 \\
10-Caudal peduncle depth & 15.8 & $13.3-16.3$ & 15.3 & 16.2 & $14.5-16.2$ & 15.6 \\
11-Snout length & 22.7 & $20.9-27.2$ & 22.5 & 26.9 & $23.3-28.4$ & 26.3 \\
12-Orbital diameter & 40.5 & $37.8-48.5$ & 42.4 & 41.4 & $39.2-41.7$ & 40.8 \\
13-Postorbital length & 44.6 & $36.0-47.2$ & 42.7 & 36.6 & $35.3-38.2$ & 37.0 \\
\hline
\end{tabular}


hook on the gonopodial appendix located in its inner surface and close to its base; and (4) absence of inconspicuous vertical bars along body sides. Phalloceros tupinamba can be distinguished from $P$. aspilos by the presence of lateral spot and by the predorsal length of males (57.5-59.8 vs. 54.8-56.3\% SL, respectively). Phalloceros tupinamba can be distinguished from $P$. leptokeras by the lateral spot normally pigmented, vertically elongated, and horizontally covering the length corresponding to one scale length and located on the $16^{\text {th }}, 17^{\text {th }}, 18^{\text {th }}$ or $19^{\text {th }}$ scale of longitudinal line (vs. densely pigmented, rectangle like, horizontally covering the length corresponding to two or three scales length located on the $14^{\text {th }}$ or $15^{\text {th }}$ (very rarely $16^{\text {th }}$ ) scale of longitudinal line.

Description. Morphometric data in Tables 7 and 8. Range of SL: 22.9 to $44.0 \mathrm{~mm}$ (females), 17.0 to $27.4 \mathrm{~mm}$ (males). Dorsalfin rays: 7 [1], 8* [34]. Branched pectoral-fin rays: 6 [3], 7* [29]. Pelvic-fin rays: 5* [6] (males), 5 [30] (females). Anal-fin rays of females: 10 [1], 11 [26]. Anal-fin rays of males: 9 [6], 10* [1]. Branched caudal-fin rays: 10 [1], 11 [2], 12* [26], 13 [3]. Predorsal scales: 13 [4], 14* [18]. Longitudinal series of scales: $27 *$ [11], 28 [5], 29 [19]. Series of scales around caudal peduncle: 14 [1], 16* [35]. Transverse series of scales: $7 *$ [36]. Serrae on R4p: 11 [3], 12 [1], 13 [2], 14* [1]. Epipleural ribs: 13 [2]. Pleural ribs: 14 [2] Vertebrae: 31 [1], 32 [1]. Female urogenital papilla slightly left turned and with lateral ramus. Female urogenital papilla lobed or little flattened. Hooks of gonopodial appendix large and sickle like (Fig. 14).

Color in alcohol. Eye grey iridescent with greenish brown pupil. Ground color pale brown, darker in upper half. Border of scales and subjacent skin replete with brown chromatophores, more concentrated at short distance from scale border, forming v-band conferring reticulate pattern to body sides, mainly on upper half. Brown chromatophores scattered through whole body, more concentrated on dorsal portion, mainly on head, snout, opercle, and ventral surface of mandible. Lateral spot narrow vertically elongated, covering approximately one scale on both horizontal and vertical directions. Faint band of chromatophores on distal border of dorsal fin. Faint band of chromatophores near dorsal-fin base. Fins hyaline. Faint patch of dark chromatophores along R3. Anal fin of females hyaline; few chromatophores scattered through first three rays but not forming defined patch of pigmentation.

Etymology. From the Tupi tupinamba alluding to the indigenous tribe that inhabited the region in Pre-Cabralian times. A noun in apposition.

Distribution. Phalloceros tupinamba is known from the rio Itamambuca and rio Macacu drainages, small coastal drainages of São Paulo and Rio de Janeiro States of Brazil (Fig. 12).

Remarks. The distribution of Phalloceros tupinamba is not continuous. The comparison between specimens from rio

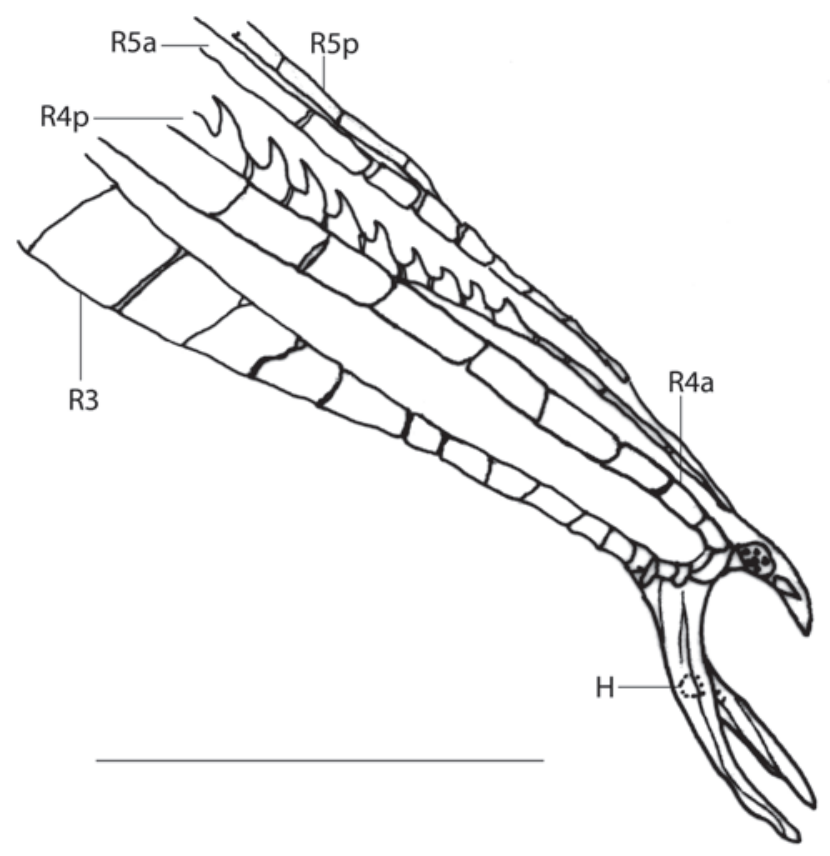

Fig. 14. Gonopodium tip of Phalloceros tupinamba, MCP 20585. R3, R4a, R4p, R5a, R5p indicate gonopodial rays. Scale bar $1 \mathrm{~mm}$.

Macacu and rio Itamambuca has revealed no significant difference that could justify their recognition as distinct species. Until new evidence is available it is plausible to consider the distribution gap is probably due to the lack of collecting samples. Maybe new collecting efforts may reveal that the species also inhabits the coastal drainages between rio Macacu and rio Itamambuca.

\section{Phalloceros aspilos + P. leptokeras Clade 79, Lucinda \& Reis (2005).}

Diagnosis. Members of this clade share the following not uniquely derived and/or reversed features: (1) third basibranchial ossified and toothed [30-1]; and (2) nine analfin rays in males [85-4].

\section{Phalloceros leptokeras, new species}

Figs. 15-17

Phalloceros sp. n. F Lucinda \& Reis (2005).

Holotype. MNRJ 23606, rio São Francisco, tributary to rio Paquequer, Fazenda São Francisco de Paula, approximately $22^{\circ} 2^{\prime}$ S 4247’W, Sapucaia, Rio de Janeiro, Brazil, 6 Aug 1990, D.A. Halboth etal.

Paratypes. BRAZIL. Rio de Janeiro. MCP 30512, 6/4* and MNRJ 22509, 36, collected with the holotype. MCP 13736, 3, rio São Francisco II, on road from Além Paraíba to Teresópolis, 9 Sep 1989, C.A.S. Lucena et al. MNRJ 14497, 8, Teresópolis, rio Paquequer on road BR 116, upstream Teresópolis, 17 Feb 1990. MNRJ 15525, 2, Teresópolis, córrego Brejal, under bridge at Fazenda Rio Bonito, 17 Oct 1989, D.A. Halboth. MNRJ 22510, 5, Teresópolis, ribeirão 


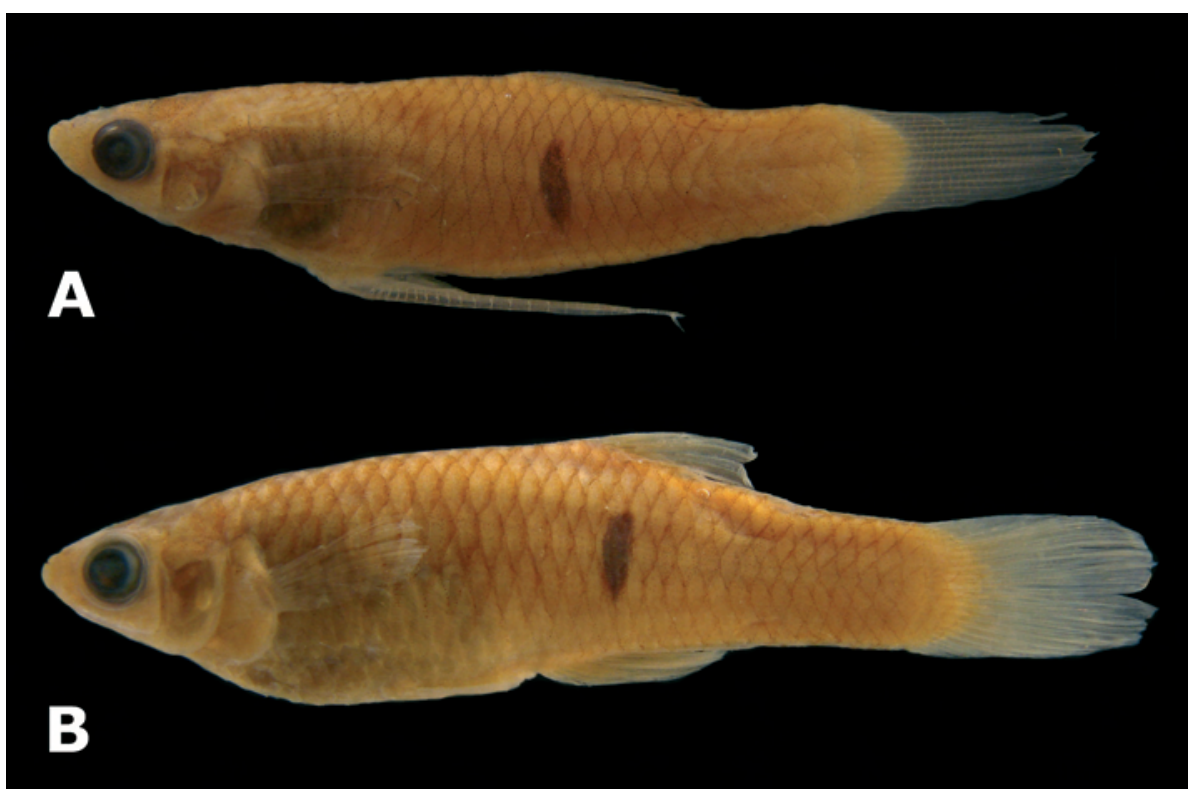

Fig. 15. Phalloceros leptokeras. (A) Holotype, male, $22.3 \mathrm{~mm}$ SL, MNRJ 23606, rio São Francisco, tributary to rio Paquequer Fazenda São Francisco de Paula, Sapucaia, Rio de Janeiro, Brazil; (B) paratype, female, MNRJ 22509, 33.7 mm SL, collected with the holotype.

Santa Rita (tributary to the left margin of rio Paquequer), near Fazenda Santo Afonso, 11 Mar 1996, P.A. Buckup et al.

Diagnosis. Phalloceros leptokeras can be diagnosed by the following uniquely derived autapomorphy: typical densely pigmented rectangle like lateral spot located on the $14^{\text {th }}$ or $15^{\text {th }}$ (very rarely $16^{\text {th }}$ ) scale of longitudinal line [134-5*] (Fig. 15). Furthermore, $P$. leptokeras is readily distinguished from its congeners, except $P$. tupinamba and $P$. aspilos, (1) by the presence a lateral ramus of the female urogenital papilla (Fig. 16); (2) female urogenital papilla left turned (Fig. 16); (3) large sickle like hook on the gonopodial appendix located in its inner surface and close to its base (Fig. 17); and (4) absence of vertical bars along body sides (Fig. 15). Phalloceros leptokeras can be distinguished from $P$. aspilos by the presence of lateral spot (vs. spot absent). Phalloceros leptokeras can be distinguished from $P$. tupinamba by the flattened female urogenital papilla (vs. not-flattened in P. tupinamba) and by the lateral spot densely pigmented, rectangle like, horizontally covering the length corresponding to two or three scales length (vs. normally pigmented, vertically elongated, and horizontally covering the length corresponding to the length of one scale in P. tupinamba).

Description. Morphometric data in Tables 1 and 2. Range of SL: 21.7 to $36.5 \mathrm{~mm}$ (females), 16.5 to $23.7 \mathrm{~mm}$ (males). Dorsalfin rays: $8 *$ [20]. Branched pectoral-fin rays: 6 [1], $7 *$ [14]. Pelvic-fin rays: $5 *$ [8] (males), 5 [11] (females). Anal-fin rays of females: 11 [11]. Anal-fin rays of males: 8 [1], 9* [8]. Branched caudal-fin rays: 10 [1], 11 [3], 12* [10], 13 [1]. Predorsal scales: 14* [10]. Longitudinal series of scales: 28* [7], 29 [9]. Series of scales around caudal peduncle: 16* [20]. Transverse series of scales: $7 *$ [20]. Serrae on R4p: 11 [3], 12 [4], 13 [1], 14
[1]. Epipleural ribs: 12 [1], 13 [3]. Pleural ribs: 14* [2], 15 [1], 16 [1]. Vertebrae: 32 [3], 33 [1]. Female urogenital papilla slightly left turned and with lateral ramus. Female urogenital papilla very flattened. Hooks of gonopodial appendix large and sickle like (Fig. 17).

Color in alcohol. Eye greyish iridescent black with greenish brown pupil. Ground color cream, darker in upper half. Border of scales and subjacent skin replete with brown chromato-

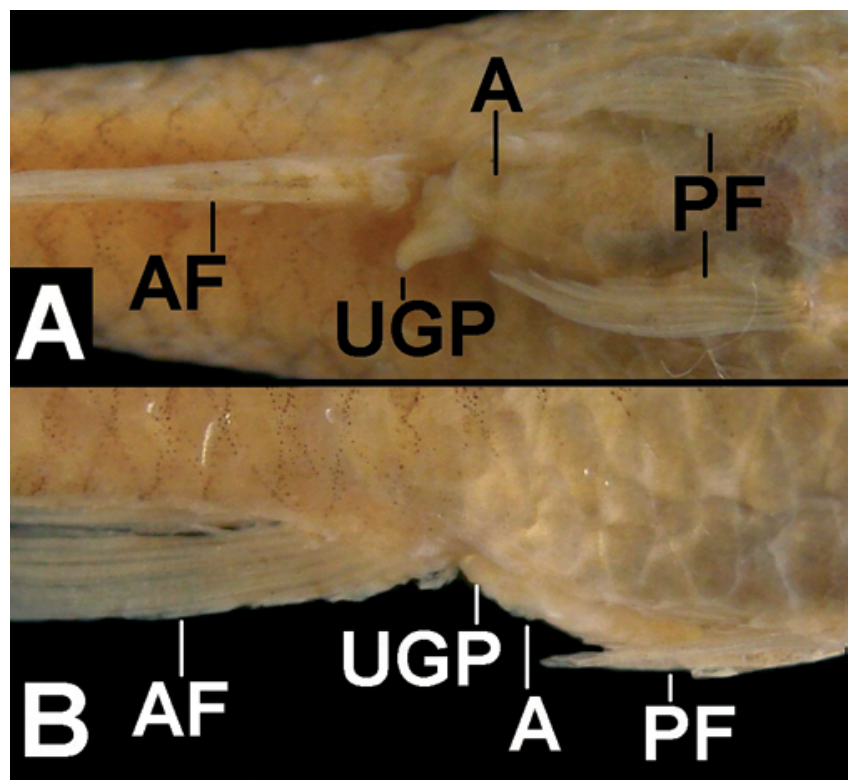

Fig. 16. Urogenital region of female of Phalloceros leptokeras, MCP 30512. (A) ventral view; (B) lateral view of left side. $A=$ anus; $\mathrm{AF}=$ anal fin; $\mathrm{PF}=$ pelvic fin; $\mathrm{UGP}=$ urogenital papilla. Scale bar $1 \mathrm{~mm}$. 


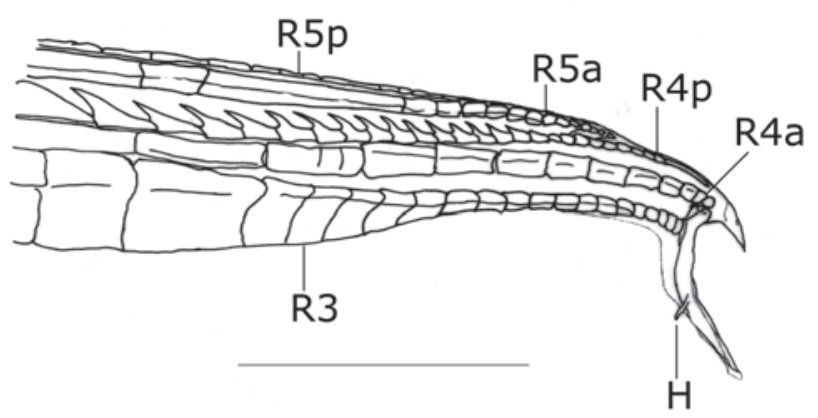

Fig. 17. Gonopodium tip of Phalloceros leptokeras, MCP 30512. (a) ventrolateral view; (b) lateral view. R3, R4a, R4p, $\mathrm{R} 5 \mathrm{a}, \mathrm{R} 5 \mathrm{p}$ indicate gonopodial rays. $\mathrm{H}=$ hook. Scale bar $1 \mathrm{~mm}$.

phores, more concentrated at short distance from scale border, conferring reticulate pattern to body sides, mainly on upper half. Brown chromatophores scattered through whole body, more concentrated on dorsal portion, mainly on head, snout, opercle, and ventral surface of mandible. Lateral spot densely pigmented, rectangle like, horizontally covering two or three scales, located on $14^{\text {th }}$ or $15^{\text {th }}$ (very rarely $16^{\text {th }}$ ) scale of longitudinal line. Inconspicuous vertical bars along flanks present or absent. Dorsal-fin membrane hyaline. Faint band of chromatophores on distal border of dorsal fin. Faint band of chromatophores near dorsal-fin base. Pectoral, pelvic, and caudal fins hyaline. Dark brown line along R3. Anal fin of females hyaline; few chromatophores scattered through first three rays but not forming defined patch of pigmentation.

Etymology. From the Greek, $\lambda \varepsilon \pi \tau o \varsigma,-\eta,-o v$ [= leptos, é, -ón], adj. masc. nom. sg., meaning strait, narrow plus $\kappa \varepsilon \rho \alpha \varsigma$ [= kéras], n. neut. nom. sg. i.f., meaning horn, alluding to the slender gonopodial appendix. $\Lambda \varepsilon \pi \tau$ б $\varepsilon \rho \alpha \varsigma$ (leptokeras) is a noun in apposition.

Distribution. Middle portions of rio Paraíba do Sul drainage (Fig. 18).

Remarks. Phalloceros leptokeras is restricted to the middle portions of rio Paraíba do Sul drainage. This species is sympatric and sometimes syntopic with $P$. harpagos. Phalloceros leptokeras can be easily distinguished from $P$. harpagos by (1) the hook of gonopodial appendix (large sickle like and located in inner surface of gonopodial appendix and close to its base vs. small and located in the outer surface of gonopodial appendix and near its tip, respectively); (2) female urogenital papillae (left turned and lateral ramus present vs. straight and lacking lateral ramus, respectively); (3) lateral spot (densely pigmented, rectangle like, horizontally covering two or three scales located on the $14^{\text {th }}$ or $15^{\text {th }}$ [very rarely $16^{\text {th }}$ ] scale of longitudinal line $v s$. normally pigmented, vertically elongated, and horizontally covering one scale and located on the $15^{\text {th }} 16^{\text {th }}, 17^{\text {th }}, 18^{\text {th }}$ or $19^{\text {th }}$ scale of longitudinal line, respectively); (4) inconspicuous vertical bars along body sides (present vs. absent, respectively).

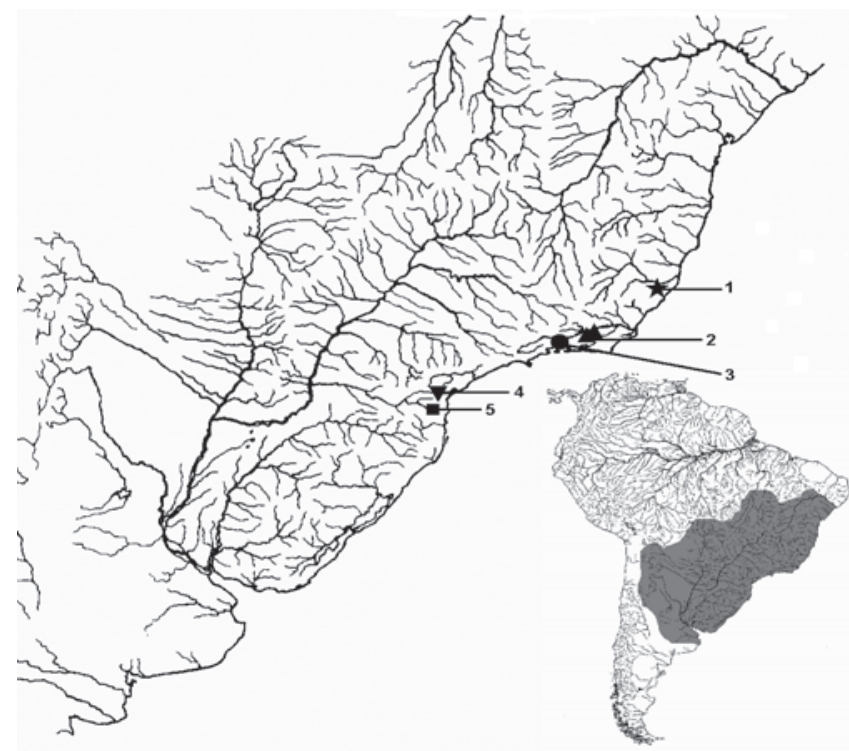

Fig. 18. Collection localities of Phalloceros elachistos (fivepointed star, 1), P. leptokeras (triangle, 2), P. aspilos (circle, 3), P. alessandrae (inverted triangle, 4), and P. megapolos (square, 5). Some symbols represent more than one lot or locality. Numbers represent type localities. The inset is the range of the genus.

\section{Phalloceros aspilos, new species}

Figs. 19, 20

Phalloceros sp. n. G Lucinda \& Reis (2005).

Holotype. MNRJ 23607, rio Parati-Mirim, near km 202 of road BR 101, upstream Vila do Patrimônio, approximately $23^{\circ} 14^{\prime} \mathrm{S}$ 44³8'W, Rio de Janeiro, Brazil, 29 Jan 1989, H. São Thiago et al. Paratypes. BRAZIL. Rio de Janeiro. MCP 30509, 6/2*; and MNRJ 11727, 7, collected with the holotype. MCP 20594, 7, Parati, creek affluent to rio Parati-Mirim, near km 207 of BR 101, road from Parati to Ubatuba, $23^{\circ} 20^{\prime} 28^{\prime \prime S} 44^{\circ} 44^{\prime} 45^{\prime \prime W}, 22$ Jan 1997, J.F.P. Silva et al. MCP 31350, 36, Parati, small stream affluent to rio

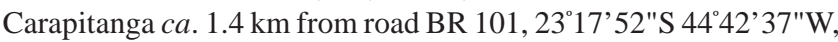
17 Oct 2002, V.A. Bertaco et al.

Diagnosis. Phalloceros aspilos can be diagnosed by the following uniquely derived autapomorphy: hypural plate almost bipartite, with very large aperture [131-3*]. Furthermore, $P$. aspilos is readily distinguished from its congeners, except $P$. tupinamba and $P$. leptokeras by (1) the presence of a lateral ramus of the female urogenital papilla; (2) female urogenital papilla left turned; (3) large sickle like hook on the gonopodial appendix located in its inner surface and close to its base (Fig. 20); and (4) absence of inconspicuous vertical bars along body sides (Fig. 19). Phalloceros aspilos can be distinguished from $P$. leptokeras and P. tupinamba by the absence of lateral spot. Phalloceros aspilos can also be distinguished from P. tupinamba by the predorsal length of males (54.8-56.3 vs. 57.5-59.7\% SL, respectively). 


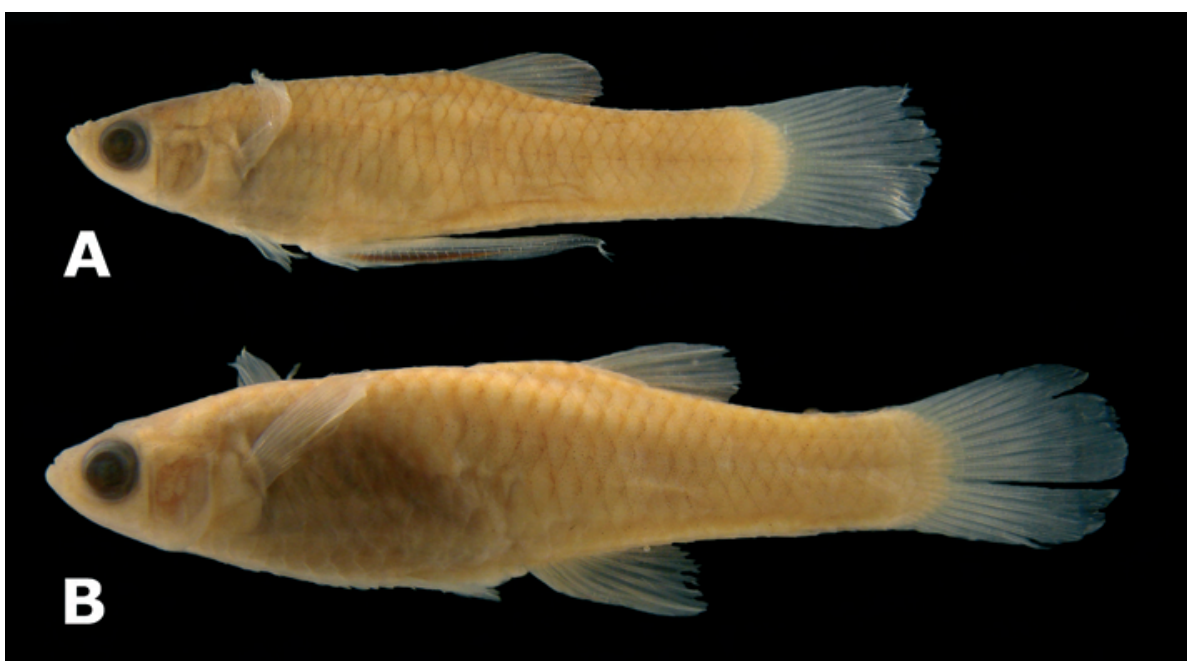

Fig. 19. Phalloceros aspilos. (A) Holotype, male, 23.6 mm SL, MNRJ 23607, rio Parati-Mirim, near km 202 of road BR 101 , upstream Vila do Patrimônio; (B) paratype, female, MCP 30509, 33.7 mm SL, collected with the holotype.

Description. Morphometric data in Tables 5 and 6. Range of SL: 25.8 to $38.3 \mathrm{~mm}$ (females), 22.2 to $23.8 \mathrm{~mm}$ (males). Dorsalfin rays: 7 [2], 8* [14]. Branched pectoral-fin rays: 6 [3], 7* [10]. Pelvic-fin rays: 5* [3] (males), 5 [13] (females). Anal-fin rays of females: 10 [2], 11 [11]. Anal-fin rays of males: 9* [3]. Branched caudal-fin rays: $12 *$ [10], 13 [3], 14 [2]. Predorsal scales: 14 [7], 15 [3]. Longitudinal series of scales: 28 [1], 29 [10], 30* [4]. Series of scales around caudal peduncle: $16^{*}$ [16]. Transverse series of scales: 7* [16]. Serrae on R4p: 13 [2], 15* [1]. Epipleural ribs: 12 [1]. Pleural ribs: 15 [1]. Vertebrae: 33 [1]. Female urogenital papilla slightly left turned and with lateral ramus. Hooks of gonopodial appendix large and sickle like (Fig. 20).

Color in alcohol. Eye greyish iridescent black with greenish brown pupil. Ground color cream, darker in upper half. Border of scales and subjacent skin replete with brown chromatophores, more concentrated at short distance from scale border, conferring reticulate pattern to body sides, mainly on upper half. Brown chromatophores scattered through whole body, more concentrated on dorsal portion, mainly on head, snout, opercle, and ventral surface of mandible. No lateral spot. Dorsal-fin membrane hyaline, except for faint band of chromatophores on distal border of dorsal fin and near dorsal-fin base. Pectoral, pelvic, and caudal fins hyaline. Dark brown line along

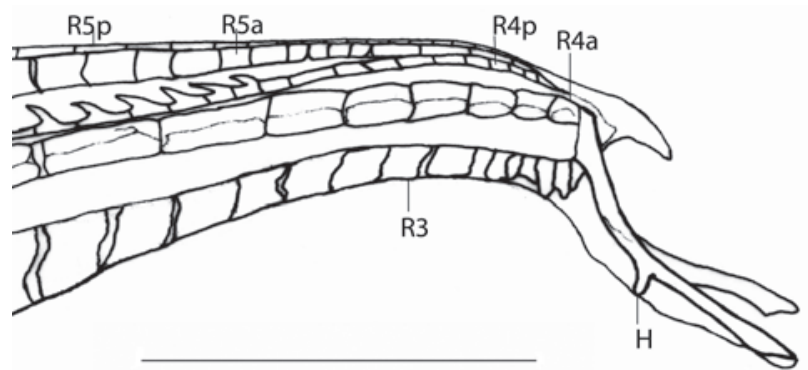

Fig. 20. Gonopodium tip of Phalloceros aspilos, MCP 30509. R3, R4a, R4p, R5a, R5p indicate gonopodial rays. Scale bar $1 \mathrm{~mm}$.
R3. Anal fin of females hyaline; chromatophores scattered through first three rays and forming patch of dark pigmentation.

Etymology. From the Greek, $\alpha \sigma \pi \imath \lambda \mathrm{o} \varsigma,-o v$, [ = aspilos, -on], adj. m. nom. sg., stainless, without spots, spotless; alluding to the absence of the lateral spot. An adjective.

Distribution. Rio Parati-Mirim, Rio de Janeiro (Fig. 18).

$$
\begin{gathered}
\text { Phalloceros elachistos }+ \text { P. titthos }+ \text { P. enneaktinos }+ \\
\text { P. harpagos }+ \text { P. ocellatus }+ \text { P. alessandrae }+ \\
\text { P. malabarbai }+ \text { P. megapolos }+ \text { P. lucenorum }+ \text { P. uai }+ \\
\text { P. buckupi }+ \text { P. anisophallos }+ \text { P. pellos }+ \text { P. spiloura }+ \\
\text { P. reisi } \\
\text { Clade 82, Lucinda \& Reis (2005) }
\end{gathered}
$$

Diagnosis. Members of this clade share the following not uniquely derived and/or reversed features: (1) dorsolateral process of basipterygium large in adult males [36-1]; and (2) hooks on paired gonopodial appendix (at least the right one) not sickle like [94-2*].

\section{Phalloceros elachistos, new species \\ Figs. 21, 22}

Phalloceros sp. n. U Lucinda \& Reis (2005).

Holotype. MCP 30468, córrego Limoeiro, at Praça Oito, approximately 1955'S 4050’W, Itarana, Espírito Santo, Brazil, 18 Oct 2000, R.L. Teixeira \& P.S. Miller.

Paratypes. BRAZIL. Espírito Santo. Rio Doce Drainage: MCP 30023, 90/5*, collected with the holotype. MCP 30021, 6, Itarana, córrego Jaboticas, 18 Oct 2000, R.L. Teixeira \& P.S. Miller. MCP 30022, 1, Itarana, córrego Limoeiro, at Praça Oito, 8 Feb 2001, R.L. Teixeira \& P.S. Miller. Rio Santa Maria da Vitória drainage: MNRJ 11645, 13, Santa Leopoldina, rio da Prata along road ES-080, 16 Feb 1988, P.A. Buckup et al. UMMZ 215314, 13, same data as for 


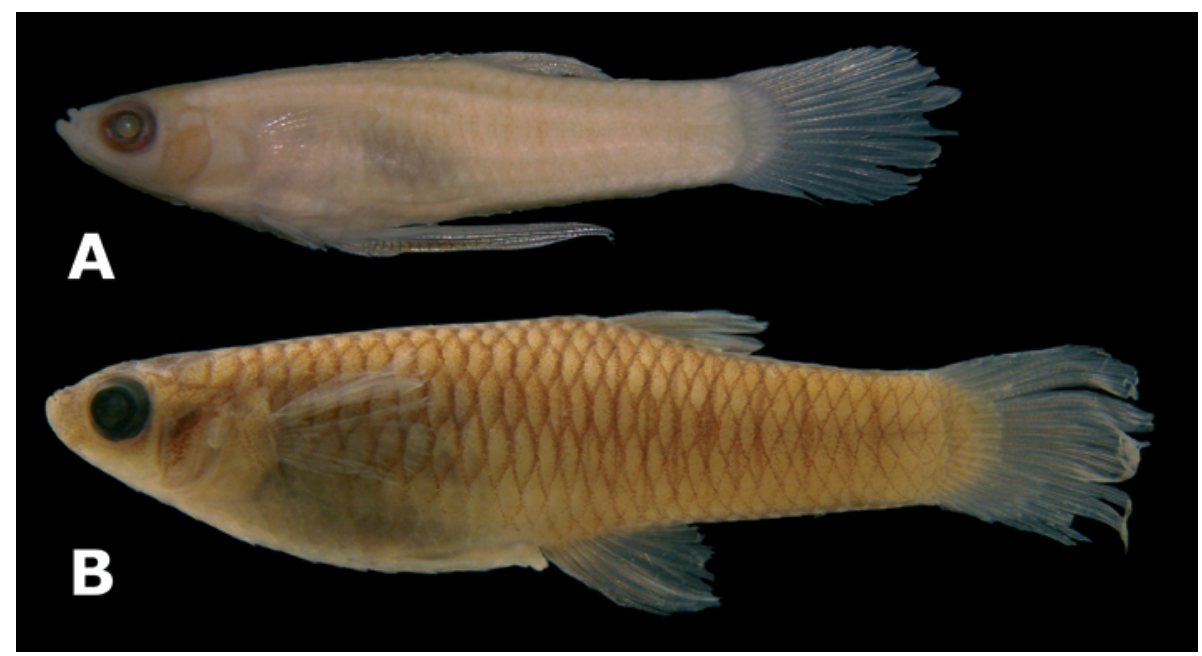

Fig. 21. Phalloceros elachistos. (A) Holotype, male, 19.9 mm SL, MCP 30468, córrego Limoeiro, at Praça Oito, Itarana, Espírito Santo, Brazil; (B) paratype, female, MCP 30023, 31.5 mm SL, collected with the holotype.

MNRJ 11645. Rio Jucu drainage: USNM 257031, 13, southern branch of rio Jucu between Isabel and Viana on road BR 262, 13 Nov 1982, N.A. Menezes et al. Rio Timbuí drainage: MCP 29435, 3, Santa Teresa, rio da Penha, Sítio do Rubinho, 24 Oct 2001, R.L. Teixeira. MNRJ 11640, 29, Santa Tereza, córrego at Valsugana Velha, 16 Feb 1988, P.A. Buckup et al. UMMZ 215307, 31/4*, same data as for MNRJ 11640.

Diagnosis. Phalloceros elachistos can be distinguished from $P$. anisophallos, $P$. megapolos, $P$. spiloura, $P$. reisi, $P$. buckupi, $P$. alessandrae, $P$. lucenorum, $P$. uai, $P$. pellos, and $P$. malabarbai by the female urogenital papilla straight along midline and located between the anus and the base of first anal-fin ray (vs. curved to the right, located laterally; border of the anal aperture in contact with the first anal-fin ray). Phalloceros elachistos can be distinguished from P. tupinamba, $P$. leptokeras, and $P$. aspilos by (1) the female urogenital papilla straight along midline (vs. slightly left turned); (2) absence of a lateral ramus of the female urogenital papilla (vs. lateral ramus present); and (3) small and simple hook in gonopodial appendix (vs. large sickle like hook) (Fig. 22). Phalloceros elachistos can be distinguished from $P$. caudimaculatus, $P$. heptaktinos, $P$. ocellatus, $P$. mikrommatos, and $P$. leticiae by the possession of a hook in the gonopodial appendix (vs. hook absent). Phalloceros elachistos is readily distinguished from $P$. titthos by the absence of symphyseal papillae on mandible of large females (vs. symphyseal papillae present); and from $P$. enneaktinos by the possession of seven or eight dorsal-fin rays (vs. nine) (see remarks). Phalloceros elachistos can be distinguished from $P$. harpagos by the hook of gonopodial appendix, which is very small in adults, forming a minute lateral protuberance (Fig. 22) (vs. not forming a lateral protuberancesee remarks on $P$. harpagos description). In juveniles hook (usually) is absent or (rarely) minuscule. When present in juveniles hook never situated on the appendix corner (vs. present and located on the appendix corner). Juveniles never present skin covering the tip of appendix (vs. skin present). Distal half of appendix approximately as wide as (or slightly narrower than) proximal half ( $v s$. narrower than proximal half).

Description. Morphometric data in Tables 9 and 10. Range of

Table 9. Descriptive morphometrics of female specimens of Phalloceros reisi, P. elachistos, P. enneaktinos, and P. harpagos. Measurements 1-10 are percents of standard length and measurements 11-13 are percents of head length.

\begin{tabular}{|c|c|c|c|c|c|c|c|c|}
\hline \multirow[t]{2}{*}{ Character } & \multicolumn{2}{|c|}{$\begin{array}{l}\text { Phalloceros reisi } \\
\quad \mathrm{n}=71\end{array}$} & \multicolumn{2}{|c|}{$\begin{array}{l}\text { Phalloceros elachistos } \\
n \mathrm{n}=36\end{array}$} & \multicolumn{2}{|c|}{$\begin{array}{l}\text { Phalloceros enneaktinos } \\
\mathrm{n}=8\end{array}$} & \multicolumn{2}{|c|}{$\begin{array}{l}\text { Phalloceros harpagos } \\
\qquad \mathrm{n}=407\end{array}$} \\
\hline & Range & Mean & Range & Mean & Range & Mean & Range & Mean \\
\hline Standard length (mm) & $23.2-49.9$ & 33.6 & $15.1-27.8$ & 20.8 & $23.5-35.8$ & 29.6 & $18.4-46.8$ & 29.2 \\
\hline 1-Head length & $18.4-25.4$ & 21.3 & 19.9-24.1 & 22.3 & 20.1-23.8 & 21.7 & $16.5-25.8$ & 20.9 \\
\hline 2-Snout-occipital distance & $15.0-22.5$ & 18.6 & 20.9-24.9 & 22.8 & $22.6-25.6$ & 24.3 & $17.5-26.5$ & 21.9 \\
\hline 3-Predorsal distance & $60.3-64.6$ & 62.3 & $59.7-63.8$ & 62.2 & $59.4-63.2$ & 61.2 & 57.3-66.9 & 62.0 \\
\hline 4-Dorsal-fin base length & 7.6-13.8 & 10.5 & $8.0-11.7$ & 10.1 & $9.1-12.4$ & 11.1 & 6.9-13.6 & 10.8 \\
\hline 5-Anal-fin base length & $6.6-13.2$ & 9.5 & 7.5-12.4 & 9.7 & $8.5-10.3$ & 9.2 & 7.1-12.1 & 9.7 \\
\hline 6-Body depth & 22.3-28.2 & 25.1 & 19.2-28.8 & 23.8 & $25.6-29.0$ & 27.3 & 21.1-30.7 & 25.5 \\
\hline 7-Pre-pelvic length & 41.0-45.9 & 43.6 & 40.5-44.9 & 42.9 & $42.2-45.3$ & 43.7 & 39.7-47.9 & 43.3 \\
\hline 8-Preanal length & $56.2-60.0$ & 57.9 & 53.8-59.9 & 57.1 & $54.5-59.2$ & 57.0 & $52 . .0-62.4$ & 58.0 \\
\hline 9-Postanal length & 33.9-39.2 & 36.2 & 32.6-39.2 & 36.3 & 35.4-39.2 & 37.6 & $31.5-43.3$ & 35.9 \\
\hline 10-Caudal peduncle depth & 13.2-16.2 & 14.7 & 13.6-16.9 & 15.1 & $15.3-16.5$ & 16.1 & $12.5-17.2$ & 14.9 \\
\hline 11-Snout length & $19.3-31.4$ & 25.6 & $17.8-27.0$ & 22.1 & $18.3-28.2$ & 22.3 & 15.3-33.3 & 21.5 \\
\hline 12-Orbital diameter & $28.6-42.7$ & 35.9 & $37.6-48.0$ & 42.5 & $35.1-43.4$ & 38.5 & $30.2-48.6$ & 39.6 \\
\hline 13-Postorbital length & $35.3-47.8$ & 41.3 & 35.1-45.9 & 42.0 & $32.9-45.5$ & 42.4 & $35.0-55.2$ & 46.2 \\
\hline
\end{tabular}


SL: 15.1 to $27.8 \mathrm{~mm}$ (females), 14.9 to $18.5 \mathrm{~mm}$ (males). Dorsalfin rays: 7 [1], 8* [47], 9 [1]. Branched pectoral-fin rays: 6 [8], $7 *$ [15]. Pelvic-fin rays: 5* [13] (males), 5 [31] (females). Analfin rays of females: 10 [1], 11 [29]. Anal-fin rays of males: 8 [2], 9* [15]. Branched caudal-fin rays: 10 [1], 11 [21], 12* [22], 13 [1]. Predorsal scales: 13 [2], 14 [20], 15* [1]. Longitudinal series of scales: 28* [9], 29 [39], 30 [3]. Series of scales around caudal peduncle: $16^{*}$ [55]. Transverse series of scales: 6 [1], 7* [54]. Serrae on R4p: 9 [3], 10 [6], 11* [6], 12 [1]. Epipleural ribs: 14 [3], 15 [2]. Pleural ribs: 14 [4], 15 [1]. Vertebrae: 31 [1], 32 [3], 33 [1]. Female urogenital papilla straight, located along midventral line and between anus and base of first anal-fin ray. Gonopodial appendix hook small sized. Appendix hook very small in adults, forming lateral minute protuberance (Fig. 22). Hook (usually) absent or minute (rarely) in juveniles. When present in juveniles hook never situated on appendix corner. Juveniles never possess skin-covering tip of appendix. Distal half of appendix approximately as wide as (or slightly narrower than) proximal half (Fig. 22).

Color in alcohol. Eye black with greenish brown pupil. Ground color pale brown, darker in upper half. Border of scales and subjacent skin replete with brown chromatophores, more concentrated at short distance from scale border, forming v-band conferring reticulate pattern to body sides, mainly on upper half. Brown chromatophores scattered through whole body, more concentrated on dorsal portion, mainly on head, snout, opercle, and ventral surface of mandible. Lateral dark brown spot very small, inconspicuous or absent. When present located approximately on 18th scale of longitudinal series covering approximately one scale on both horizontal and vertical directions. Inconspicuous vertical bars along flanks. Dorsalfin membrane hyaline bearing dark band of chromatophores on distal border of dorsal fin and another near dorsal-fin base. Pectoral-, pelvic- and caudal-fin rays dusky. Dark brown line along R3.

Etymology. Specific name from the Greek $\varepsilon \lambda \alpha \chi \nu \varsigma,-\varepsilon 1 \alpha[=$ elachis, -eia], adj. m. nom. sg.], small, short, little, plus the

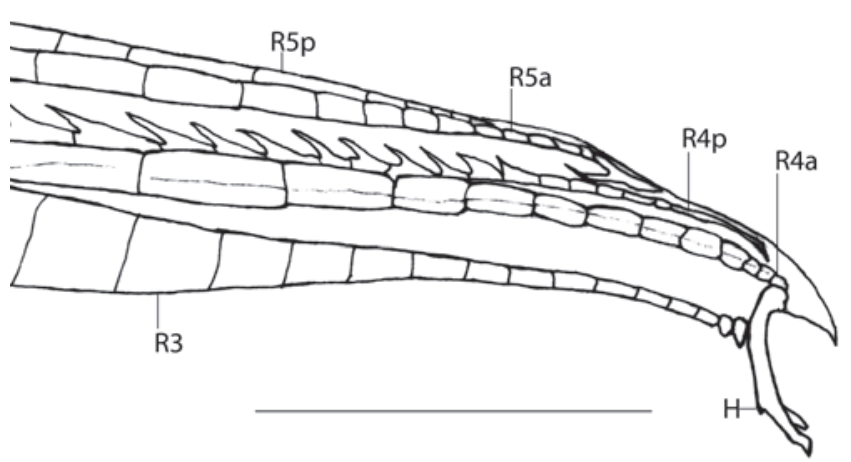

Fig. 22. Gonopodium tip of Phalloceros elachistos, MCP 30023. R3, R4a, R4p, R5a, R5p indicate gonopodial rays. Scale bar $1 \mathrm{~mm}$.

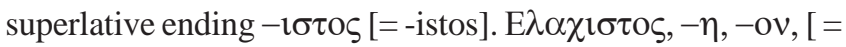
elachistos, -e, -on], meaning the least, which alludes to the small size of the specimens. An adjective, gender masculine.

Distribution. Drainages of rio Doce, Santa Maria da Vitória, Jucu, and Timbuí, coastal drainages of Espírito Santo State of Brazil (Fig. 18).

Remarks. One out of 48 studied specimens presented nine dorsal-fin rays.

\section{Phalloceros enneaktinos $+P$. titthos $+P$. harpagos $+P$. ocellatus + P. alessandrae + P. malabarbai $+P$. megapolos + P. lucenorum + P. uai + P. buckupi $+P$. anisophallos $+P$. pellos $+P$. spiloura $+P$. reisi}

Clade 80, Lucinda \& Reis (2005)

Diagnosis. Members of this clade share the following not uniquely derived and/or reversed feature: anterior cleft of anguloarticular absent [17-2*].

Table 10. Descriptive morphometrics of male specimens of Phalloceros reisi, P. elachistos, P. enneaktinos, and P. harpagos. Measurements 1-10 are percents of standard length and measurements 11-13 are percents of head length. $\mathrm{H}=$ holotype.

\begin{tabular}{|c|c|c|c|c|c|c|c|c|c|c|c|c|}
\hline \multirow[t]{2}{*}{ Character } & \multicolumn{3}{|c|}{$\begin{array}{c}\text { Phalloceros reisi } \\
\mathrm{n}=16\end{array}$} & \multicolumn{3}{|c|}{$\begin{array}{c}\text { Phalloceros elachistos } \\
\mathrm{n}=18\end{array}$} & \multicolumn{3}{|c|}{$\begin{array}{l}\text { Phalloceros enneaktinos } \\
n=7\end{array}$} & \multicolumn{3}{|c|}{$\begin{array}{c}\text { Phalloceros harpagos } \\
\mathrm{n}=262\end{array}$} \\
\hline & $\mathrm{H}$ & Range & Mean & $\mathrm{H}$ & Range & Mean & $\mathrm{H}$ & Range & Mean & $\mathrm{H}$ & Range & Mean \\
\hline Standard length (mm) & 27.3 & $17.0-27.3$ & 22.3 & 19.9 & 14.9-19.9 & 17.2 & 24.2 & $19.4-24.2$ & 22.0 & 26.9 & $14.8-34.1$ & 20.4 \\
\hline 1-Head length & 19.4 & $19.4-24.2$ & 21.8 & 21.3 & $19.8-24.4$ & 21.7 & 22.6 & $19.0-23.4$ & 21.4 & 19.4 & $17.9-25.1$ & 21.2 \\
\hline 2-Snout-occipital distance & 21.9 & $18.2-21.9$ & 20.0 & 22.1 & $21.8-25.2$ & 22.7 & 21.9 & $21.5-24.7$ & 22.8 & 20.7 & $18.1-26.3$ & 21.5 \\
\hline 3-Predorsal distance & 55.6 & $55.6-62.9$ & 57.9 & 57.2 & $55.5-61.1$ & 58.5 & 58.9 & 57.1-59.6 & 58.6 & 55.9 & 54.8-61.4 & 58.1 \\
\hline 4-Dorsal-fin base length & 13.5 & $10.0-13.5$ & 11.9 & 12.1 & $8.8-13.0$ & 10.9 & 11.3 & $9.1-12.7$ & 11.4 & 10.5 & 7.3-15.6 & 11.2 \\
\hline 5-Anal-fin base length & 6.2 & $5.6-9.7$ & 7.2 & 7.6 & 4.6-11.5 & 7.7 & 5.2 & $5.2-11.0$ & 7.4 & 8.0 & 4.8-13.1 & 7.8 \\
\hline 6-Body depth & 31.6 & $29.8-36.5$ & 32.2 & 33.0 & $28.0-34.7$ & 31.4 & 33.6 & $31.4-34.7$ & 33.1 & 35.0 & 27.7-39.5 & 33.4 \\
\hline 7-Pre-pelvic length & 30.0 & $28.2-33.8$ & 30.2 & 31.8 & $28.3-36.1$ & 30.6 & 31.6 & $27.6-33.5$ & 30.2 & 30.3 & $25.8-40.1$ & 30.2 \\
\hline 8-Preanal length & 40.6 & $38.6-43.7$ & 40.8 & 39.6 & $38.3-44.9$ & 40.3 & 43.7 & $38.3-43.7$ & 41.1 & 41.4 & $34.9-48.5$ & 40.3 \\
\hline 9-Postanal length & 58.5 & $53.7-59.0$ & 57.0 & 58.6 & $50.1-58.6$ & 56.3 & 56.9 & $53.2-58.2$ & 55.7 & 59.7 & $48.6-62.3$ & 57.2 \\
\hline 10-Caudal peduncle depth & 14.0 & $14.0-18.0$ & 15.7 & 16.2 & $14.8-17.7$ & 16.1 & 17.9 & 16.4-18.3 & 17.2 & 16.0 & $12.4-18.4$ & 16.2 \\
\hline 11-Snout length & 24.8 & $23.5-30.0$ & 26.5 & 20.2 & $18.5-27.0$ & 22.8 & 21.8 & $16.2-23.2$ & 19.9 & 24.2 & $13.2-31.3$ & 22.3 \\
\hline 12-Orbital diameter & 38.0 & 33.9-43.6 & 38.5 & 41.2 & $37.4-47.4$ & 43.5 & 37.5 & $37.5-44.3$ & 41.7 & 44.0 & $35.5-51.5$ & 43.4 \\
\hline 13-Postorbital length & 41.2 & $32.6-43.3$ & 38.8 & 43.8 & $34.1-46.7$ & 40.2 & 44.9 & 41.9-46.2 & 44.1 & 42.5 & $27.8-52.0$ & 42.0 \\
\hline
\end{tabular}




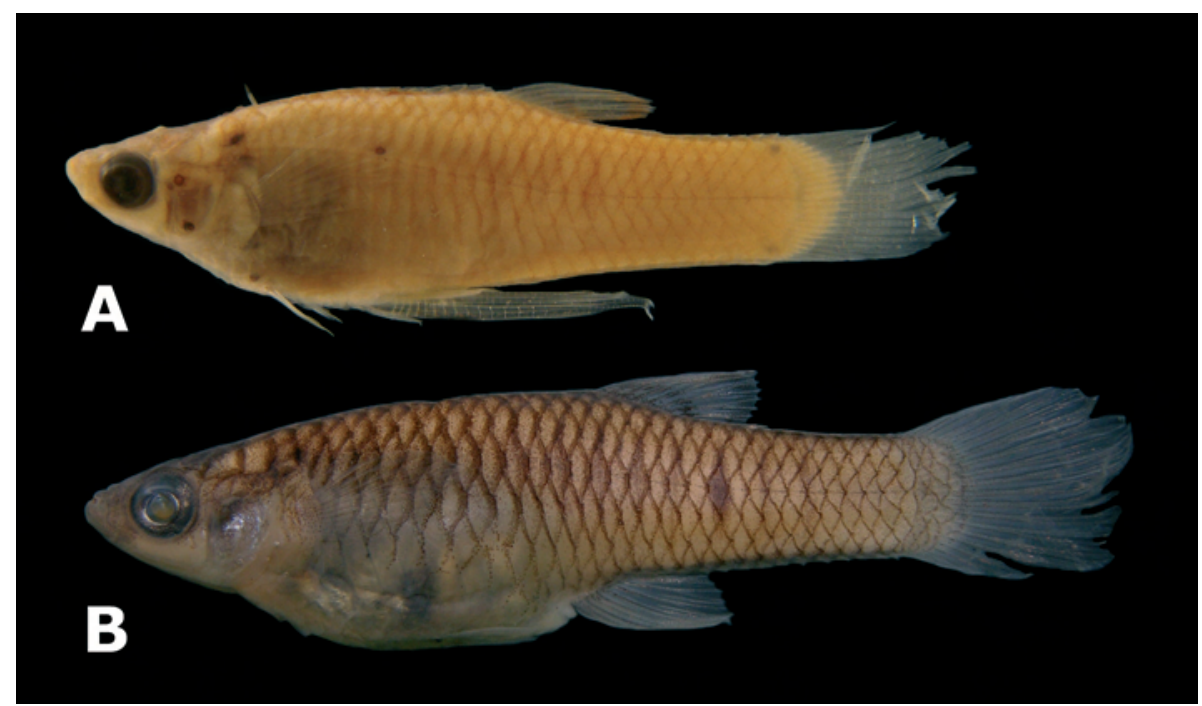

Fig. 23. Phalloceros enneaktinos. (A) Holotype, male, 24.2 mm SL, MNRJ 23609, córrego da Toca do Boi, near Condomínio Laranjeiras, Parati, Rio de Janeiro, Brazil; (B) paratype, female, MCP 31139, 30.7 mm SL, collected with the holotype.

\section{Phalloceros enneaktinos, new species}

Figs. 23, 24

Phalloceros sp. n. S Lucinda \& Reis (2005).

Holotype. MNRJ 23609, córrego da Toca do Boi, near Condomínio Laranjeiras, approximately $23^{\circ} 13^{\prime}$ S $44^{\circ} 42^{\prime} \mathrm{W}$, Parati, Rio de Janeiro, Brazil, 3 Mar 1989, P.A. Buckup.

Paratypes. BRAZIL. Rio de Janeiro. MCP 30510, 6/4*; and MNRJ 14847, 14, collected with the holotype. MCP 31139, 40, Parati, córrego da Toca do Boi, $50 \mathrm{~m}$ from Condomínio

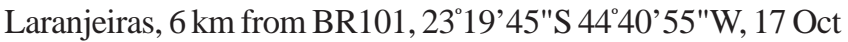
2002, V. A. Bertaco et al.

Diagnosis. Phalloceros enneaktinos can be distinguished from its congeners by the possession of nine dorsal-fin rays [64-1] (vs. eight, very rarely nine in $P$. mikrommatos, $P$. caudimaculatus, $P$. elachistos, $P$. titthos, $P$. harpagos, $P$. spiloura, and P. reisi).
Description. Morphometric data in Tables 9 and 10. Range of SL: 23.5 to $35.8 \mathrm{~mm}$ (females), 19.4 to $24.2 \mathrm{~mm}$ (males). Dorsalfin rays: $9 *$ [16]. Branched pectoral-fin rays: 6 [2], 7* [8]. Pelvic-fin rays: $5^{*}[8]$ (males), 5 [8] (females). Anal-fin rays of females: 11 [8]. Anal-fin rays of males: 9* [8]. Branched caudal-fin rays: 12 [3], 13 [6], 14 [1], 15* [2]. Predorsal scales: 13 [1], 14* [14]. Longitudinal series of scales: 28 [4], 29* [10], 30 [1]. Series of scales around caudal peduncle: $16 *$ [16]. Transverse series of scales: $7 *$ [16]. Serrae on R4p: 8 [1], 9 [2], 10* [3], 12 [1]. Epipleural ribs: 12 [1], 13 [1], 14 [2]. Pleural ribs: 13 [1], 14 [3]. Vertebrae: 31 [1], 32 [3]. Female urogenital papilla straight, located along midventral line and between anus and base of first anal-fin ray. Gonopodial appendix hook present (Fig. 24).

Color in alcohol. Eye black with greenish brown pupil. Ground color pale brown, darker in upper half. Border of scales and subjacent skin replete with brown chromatophores, more concentrated at short distance from scale border, conferring re-

Table 11. Descriptive morphometrics of female specimens of Phalloceros ocellatus, P. pellos, P. spiloura, and P. titthos. Measurements 1-10 are percents of standard length and measurements 11-13 are percents of head length. $\mathrm{H}=$ holotype.

\begin{tabular}{|c|c|c|c|c|c|c|c|c|c|}
\hline \multirow[t]{2}{*}{ Character } & \multicolumn{2}{|c|}{$\begin{array}{l}\text { Phalloceros ocellatus } \\
n=22\end{array}$} & \multicolumn{2}{|c|}{$\begin{array}{c}\text { Phalloceros pellos } \\
\mathrm{n}=9\end{array}$} & \multicolumn{2}{|c|}{$\begin{array}{c}\text { Phalloceros spiloura } \\
\mathrm{n}=28\end{array}$} & \multicolumn{3}{|c|}{$\begin{array}{c}\text { Phalloceros titthos } \\
n=23\end{array}$} \\
\hline & Range & Mean & Range & Mean & Range & Mean & $\mathrm{H}$ & Range & Mean \\
\hline Standard length (mm) & $17.7-25.2$ & 21.7 & $23.3-33.2$ & 26.4 & $19.4-33.6$ & 26.6 & 35.9 & $21.0-45.2$ & 38.8 \\
\hline 1-Head length & $21.3-25.4$ & 23.0 & $21.7-23.4$ & 22.6 & $18.5-25.1$ & 21.5 & 21.9 & $18.6-23.4$ & 20.4 \\
\hline 2-Snout-occipital distance & $18.1-24.1$ & 20.6 & $18.6-20.7$ & 19.8 & $16.5-21.2$ & 18.7 & 21.1 & $19.7-23.5$ & 21.7 \\
\hline 3-Predorsal distance & $60.3-65.2$ & 62.4 & $60.2-63.7$ & 61.8 & $62.0-67.1$ & 64.2 & 60.3 & 59.4-64.1 & 62.0 \\
\hline 4-Dorsal-fin base length & $6.7-12.6$ & 9.8 & $7.6-10.8$ & 10.0 & $7.5-11.8$ & 9.9 & 14.5 & $9.4-14.7$ & 11.3 \\
\hline 5-Anal-fin base length & $7.7-11.7$ & 9.5 & $7.4-10.7$ & 8.7 & $8.1-11.8$ & 9.6 & 7.8 & $7.8-12.4$ & 10.5 \\
\hline 6-Body depth & $23.4-29.4$ & 25.9 & $23.0-26.8$ & 24.7 & $20.8-27.7$ & 24.9 & 28.0 & $24.6-31.5$ & 27.9 \\
\hline 7-Pre-pelvic length & $42.8-47.2$ & 44.7 & $43.7-48.3$ & 45.3 & $41.3-47.3$ & 43.9 & 46.3 & 41.1-46.9 & 44.2 \\
\hline 8-Preanal length & $57.2-60.4$ & 58.9 & $56.0-60.8$ & 57.6 & $55.5-60.1$ & 57.4 & 62.1 & 54.3-62.1 & 59.3 \\
\hline 9-Postanal length & $34.3-38.5$ & 35.9 & $35.3-38.7$ & 37.1 & $31.9-39.2$ & 36.1 & 36.5 & $32.8-41.9$ & 35.6 \\
\hline 10-Caudal peduncle depth & $14.6-16.8$ & 15.9 & $14.1-16.8$ & 14.8 & $13.8-17.7$ & 15.7 & 15.3 & 13.9-16.6 & 15.2 \\
\hline 11-Snout length & $20.9-32.0$ & 25.5 & $19.9-30.0$ & 24.7 & $17.3-27.5$ & 22.8 & 20.2 & $17.3-26.7$ & 21.5 \\
\hline 12-Orbital diameter & $39.5-54.9$ & 43.8 & $38.9-48.7$ & 41.4 & $33.3-42.7$ & 38.2 & 37.2 & $33.7-40.9$ & 38.0 \\
\hline 13-Postorbital length & $24.8-39.3$ & 34.3 & $35.1-43.2$ & 40.2 & $37.8-53.2$ & 43.6 & 45.2 & $42.4-50.8$ & 47.1 \\
\hline
\end{tabular}




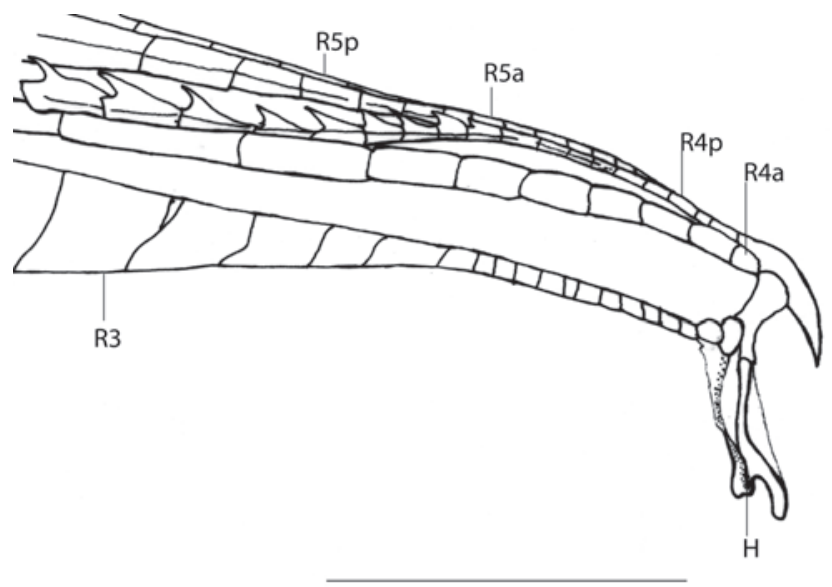

Fig. 24. Gonopodium tip of Phalloceros enneaktinos, MCP 30510. R3, R4a, R4p, R5a, R5p indicate gonopodial rays. Scale bar $1 \mathrm{~mm}$.

ticulate pattern to body sides, mainly on upper half. Brown chromatophores scattered through whole body, more concentrated on dorsal portion, mainly on head, snout, opercle, and ventral surface of mandible. Lateral dark brown spot absent or inconspicuous. Lateral spot, when present, small and covering approximately one scale on horizontal and vertical directions. Dorsal-fin membrane hyaline. Dark band of chromatophores on distal border of dorsal fin. Dark band of chromatophores near dorsal-fin base. Pectoral, pelvic, and caudal fins hyaline. Dark brown line along R3.

Etymology. From the Greek عvvع $\alpha \varsigma$ [= enneás] (num. i.f.), meaning nine, and $\alpha \kappa \tau \iota v o \zeta$ [= aktinos] (n. f. nom. pl.), meaning rays. A noun in apposition alluding to the number of dorsalfin rays.

Distribution. Phalloceros enneaktinos is only known from the type locality in the Córrego da Toca do Boi, Rio de Janeiro (Fig. 4).

\section{Phalloceros titthos, new species}

Figs. 25, 26

Phalloceros sp. n. T Lucinda \& Reis (2005).

Holotype. MZUSP 79670, creek near beach, approx. 2553'S 48³7’W, Guaratuba, Paraná, Brazil, 23 Sep 1977, Expedition MZUSP/USNM.

Paratypes. BRAZIL. Paraná. MZUSP 43467, 26/3*, collected with the holotype.

Non-types. BRAZIL. Paraná. USNM 297945, 13/2*, rio da Praia, near Guaratuba, 18 Feb 1988, R.M.C. Castro.

Diagnosis. Phalloceros titthos can be distinguished from its congeners by the possession of very large papilla at the mandibular symphysis of large adult females (Fig. 26).

Description. Morphometric data in Tables 11 and 12. Range of SL: 21.0 to $45.2 \mathrm{~mm}$ (females), 15.1 to $25.8 \mathrm{~mm}$ (males). Dorsal-fin rays: 8* [21], 9 [2]. Branched pectoral-fin rays: 6 [4], 7* [14]. Pelvic-fin rays: 5 [3] (males), 4 [1], 5* [19] (females). Analfin rays of females: $11^{*}$ [20]. Anal-fin rays of males: 9* [3]. Branched caudal-fin rays: 10 [1], 12* [14], 13 [1]. Predorsal scales: $13 *$ [8], 14 [11]. Longitudinal series of scales: 27 [2], $28 *$ [5], 29 [16]. Series of scales around caudal peduncle: $16 *$ [23]. Transverse series of scales: $7^{*}$ [23]. Serrae on R4p: 7 [1], 8 [1], 9 [3], 10 [1], 12 [1], 13 [2]. Epipleural ribs: 12 [2], 13 [1]. Pleural ribs: 13 [1], 14 [2]. Vertebrae: 30 [1], 32 [2]. Symphyseal papillae present (Fig. 26). Female urogenital papilla straight, located along midventral line and between anus and base of first anal-fin ray. Gonopodial appendix hook present.

Color in alcohol. Eye black with greenish brown pupil. Background coloration dark brown, darker in upper half. Overall appearance dark. Border of scales and subjacent skin replete with brown chromatophores, more concentrated at short distance from scale border, conferring reticulate pattern to whole flanks. Brown chromatophores scattered through whole body, more concentrated on dorsal portion, mainly on head, snout, opercle, and ventral surface of mandible. Margin of scales on

Table 12. Descriptive morphometrics of male specimens of Phalloceros ocellatus, P. pellos, P. spiloura, and P. titthos. Measurements 1-10 are percents of standard length and measurements 11-13 are percents of head length. $\mathrm{H}=$ holotype.

\begin{tabular}{|c|c|c|c|c|c|c|c|c|c|c|}
\hline \multirow[t]{2}{*}{ Character } & \multicolumn{3}{|c|}{ Phalloceros ocellatus } & \multicolumn{3}{|c|}{ Phalloceros pellos } & \multicolumn{3}{|c|}{ Phalloceros spiloura } & \multirow[t]{2}{*}{$\begin{array}{l}\text { Phalloceros titthos } \\
n=1\end{array}$} \\
\hline & $\mathrm{H}$ & Range & Mean & $\mathrm{H}$ & Range & Mean & $\mathrm{H}$ & Range & Mean & \\
\hline Standard length (mm) & 16.3 & $15.4-18.5$ & 16.7 & 26.4 & $21.5-26.4$ & 24.3 & 22.0 & $18.0-22.4$ & 20.0 & 17.1 \\
\hline 1-Head length & 23.5 & $22.2-24.8$ & 23.6 & 20.2 & $20.2-24.7$ & 21.4 & 21.8 & $21.5-24.2$ & 22.4 & 20.4 \\
\hline 2-Snout-occipital distance & 20.5 & $18.2-21.8$ & 20.2 & 20.8 & $15.2-20.8$ & 19.5 & 21.0 & $16.6-21.4$ & 19.7 & 23.7 \\
\hline 3-Predorsal distance & 58.9 & $57.5-60.7$ & 59.5 & 54.8 & $54.8-58.8$ & 56.7 & 57.7 & $59.8-63.2$ & 61.2 & 58.9 \\
\hline 4-Dorsal-fin base length & 7.7 & $7.7-13.1$ & 10.9 & 11.5 & $8.4-11.5$ & 10.7 & 13.1 & $10.4-12.4$ & 11.1 & 11.5 \\
\hline 5-Anal-fin base length & 8.1 & $5.9-10.7$ & 8.6 & 6.3 & $6.3-8.9$ & 7.2 & 9.9 & $6.1-10.3$ & 7.8 & 8.7 \\
\hline 6-Body depth & 30.5 & $30.5-34.0$ & 31.9 & 31.1 & $31.1-34.5$ & 32.0 & 35.0 & 29.9-35.9 & 33.1 & 33.9 \\
\hline 7-Pre-pelvic length & 31.3 & $29.4-36.8$ & 31.4 & 27.9 & $27.9-32.1$ & 29.3 & 31.4 & $30.7-34.7$ & 32.1 & 28.4 \\
\hline 8-Preanal length & 42.4 & $39.5-45.7$ & 42.2 & 36.0 & $36.0-43.6$ & 38.8 & 41.5 & $39.6-44.3$ & 41.4 & 38.3 \\
\hline 9-Postanal length & 54.3 & $50.3-58.6$ & 53.9 & 61.7 & 53.9-61.7 & 58.9 & 55.4 & $53.2-57.4$ & 55.2 & 56.9 \\
\hline 10-Caudal peduncle depth & 17.2 & 14.6-18.1 & 16.4 & 15.3 & $14.3-16.6$ & 15.5 & 17.0 & $14.5-17.4$ & 16.5 & 16.1 \\
\hline 11-Snout length & 28.3 & $20.4-30.7$ & 25.9 & 25.6 & $22.6-26.2$ & 25.1 & 24.8 & $22.0-25.9$ & 24.1 & 19.5 \\
\hline 12-Orbital diameter & 41.9 & $39.6-48.1$ & 44.1 & 38.3 & $36.5-48.8$ & 40.0 & 45.5 & $38.3-46.3$ & 42.1 & 45.3 \\
\hline 13-Postorbital length & 34.3 & 29.3-38.2 & 34.3 & 42.2 & $30.2-44.0$ & 40.1 & 40.1 & $33.6-42.4$ & 38.5 & 40.4 \\
\hline
\end{tabular}




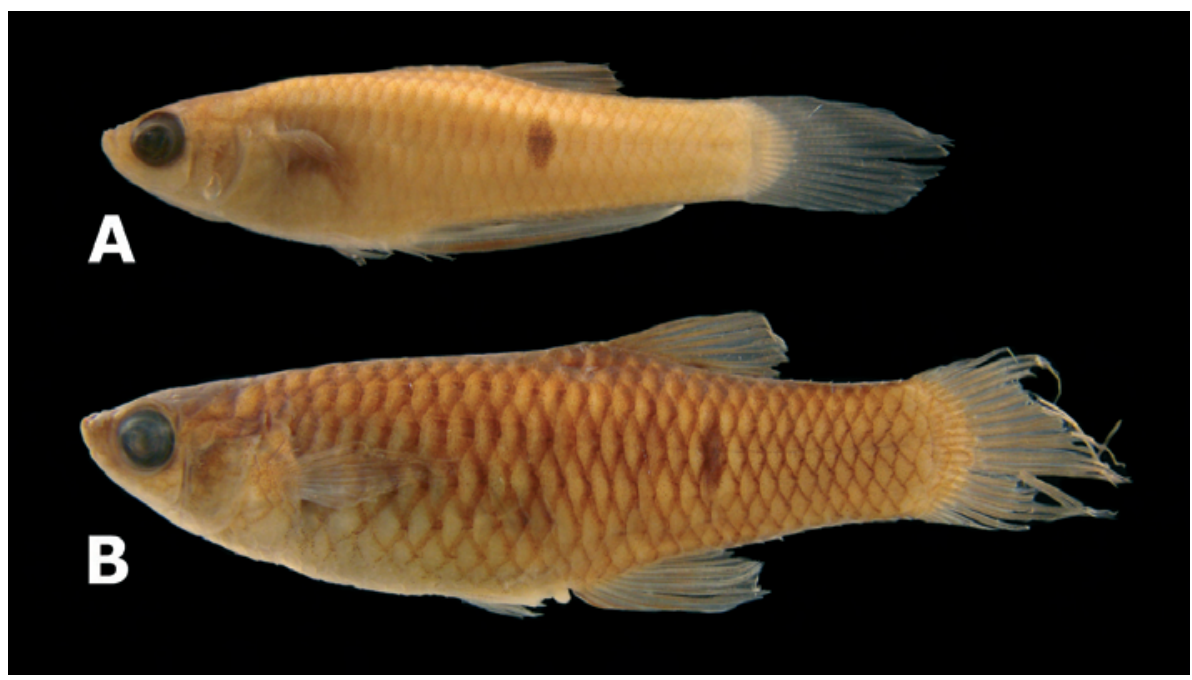

Fig. 25. Phalloceros titthos. (A) Male, 17.1 mm SL, USNM 297945, rio da Praia, near Guaratuba; (B) holotype, female, 35.9 mm SL, MZUSP 79670, creek near beach, Guaratuba, Paraná, Brazil.

prepelvic region clearly defined bordered by dark chromatophores. Lateral dark brown spot located over $17^{\text {th }}$ and $18^{\text {th }}$ scale of longitudinal series (absent in one specimen studied). Lateral spot covering approximately one or two scales on horizontal direction, and two or three scales on vertical. Inconspicuous vertical bars present in some individuals. Dorsal-fin membrane dusky, bearing dark band of chromatophores on distal border and dark band of chromatophores near dorsal-fin base. Pectoral-, pelvic- and caudal-fin rays dusky replete of brown chromatophores distributed along fin rays. First three anal-fin rays of females sometimes spotted with black. Dark brown line along R3.

Etymology. From the Greek $\tau \imath \tau \theta o \varsigma$ [= titthós], n. m. nom. sg., a woman's breast or animal's teat. In allusion to the presence of small papillae at the mandibular symphysis of large adult females. Also alluding to the fact that this character is only present in adult females.

Remarks.The gonopodial tip of this species was not described and illustrated due to the lack of adult males available for study.

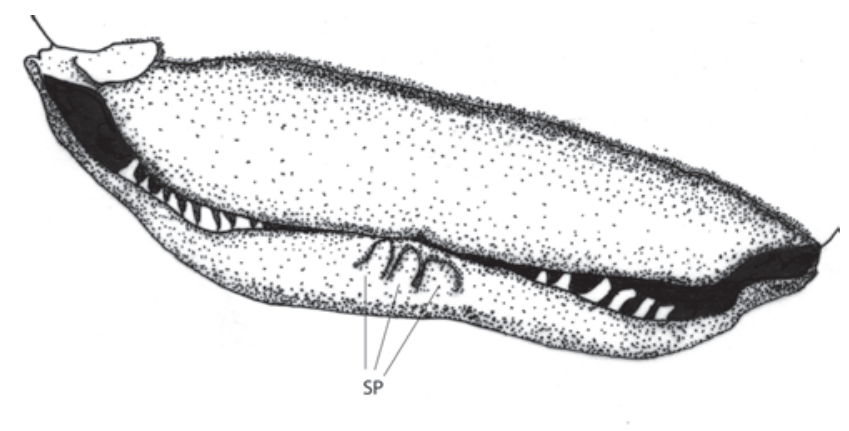

Fig. 26. Upper and lower lip of Phalloceros titthos, MZUSP 43467, showing symphyseal papilla (SP). Scale bar $1 \mathrm{~mm}$.
Distribution. Coastal drainages flowing to Baia de Guaratuba and Baia de Paranaguá in Paraná State of Brazil (Fig. 12).

Phalloceros harpagos $+P$. ocellatus $+P$. alessandrae $+P$. malabarbai + P. megapolos $+P$. lucenorum $+P$. uai $+P$. buckupi + P. anisophallos + P. pellos + P. spiloura + P. reisi

Clade 78, Lucinda \& Reis (2005).

Diagnosis. Members of this clade share the following not uniquely derived and/or reversed features: (1) dorsolateral process of basipterygium absent or small in adult males [36$0]$; and (2) nine anal-fin rays in males [85-4].

\section{Phalloceros harpagos + P. ocellatus \\ Clade 77, Lucinda \& Reis (2005).}

Diagnosis. Members of this clade share the following not uniquely derived and/or reversed features: (1) ventral invagination on anguloarticular [19-1]; and (2) spot on median region of flanks rounded [134-1].

\section{Phalloceros harpagos, new species} Figs. 27-29

Phalloceros sp. n. V Lucinda \& Reis (2005).

Holotype. MNRJ 23610, rio São Francisco, tributary to rio Paquequer Fazenda São Francisco de Paula, approx. 2159'S $42^{\circ} 54^{\prime} W$, Sapucaia, Rio de Janeiro, Brazil, 6 Aug 1990, D.A. Halboth etal.

Paratypes. BRAZIL. Rio de Janeiro. MCP 20569, 165/10*, Teresópolis, rio Paquequer, near bridge on km 86 on road BR 116, upstream Represa Guinle, 22²7’18"S 42 57’33"W, 18 Jan 1997, J.F.P. Silva et al. MCP 30508, 6/4*; and MNRJ 14745, 59, collected with the holotype.

Non-types. Rio Paraná-Paraguay basin. Río Paraguay Drainage: 


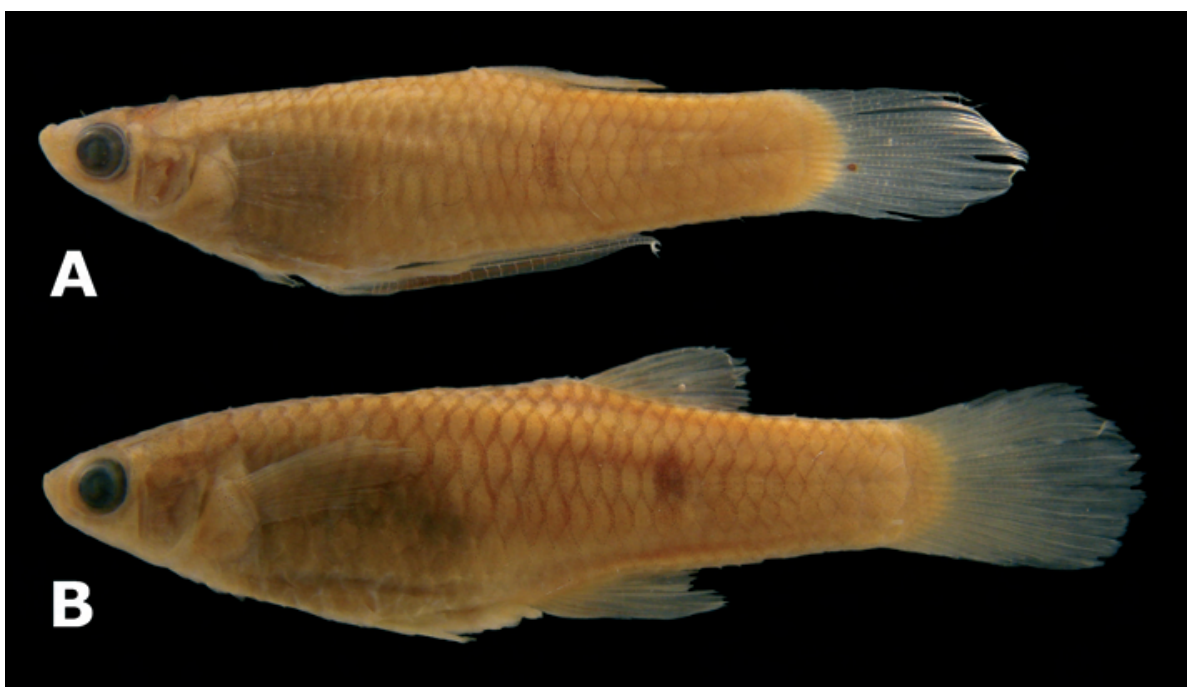

Fig. 27. Phalloceros harpagos. (A) Holotype, male, 26.9 mm SL, MNRJ 23610, rio São Francisco, tributary to rio Paquequer Fazenda São Francisco de Paula, Sapucaia, Rio de Janeiro, Brazil; (B) paratype, female, MNRJ 14745, 36.7 mm SL, collected with the holotype.

PARAGUAY. Alto Paraná. ANSP 47684, 2, Puerto Bertoni. Caaguazú. NRM 42043, 1, Arroyo Guazú, where crossing Ruta 2, 2528’23"S 56¹3’34"W. Caazapá. MNHNP 1091, 6, Parque Nacional Caaguazú, Arroyo Guazú in the park border. NRM 33811, 4, 25 km SE of Asunción, Jhuguañaró. Guairá. NRM 41893, 2, stream crossing road from Mauricio J. Troche to Independencia, 5 km S of Río Tebicuary bridge, 2540’56"S 56¹8’28"W. Misiones. ANSP 173591, 40, stream crossing Ruta 1 at km A240/E125*. Ñeembucú. USNM 181784, 11, Colonial L. Vera (pond), Tebicuary drainage. Paraguarí. AMNH 99990, 50, Arroyo Mbuyapey, in Ybycuí National Park, near Ybycuí. Lower rio Paraná Drainage: PARAGUAY. Canendiyu. AMNH 47923, 5, Arroyo Guazú-Ri 10 km above Mbuty road on old route from Stroessner to Guairá. MNHNP 428, 36, Arroyo Primavera, .. [sic] km S from Arroyo Guazú-Ri by the old road from ciudad del Este to Saltos del Guairá. UMMZ 206403, 32, Río Piratiy at Balneario Municipal, 1 km S of bridge on dirt highway just W of Salto del Guairá. Itapúa. MNHNP 1082, 30 of 104, Colonia Exparadema, Compañía Tarumá, Arroyo Tarumá. MNHNP 1098, 2, Cordillera San Rafael, Colonia Alto Verá, Arroyo Tacuary. NRM 28358, 4, stream crossing EncarnaciónHohenau road ca. 7 km from Hohenau. UMMZ 206173, 30 of 170, Arroyo San Rafael $2.2 \mathrm{~km}$ by dirt road $c a$. NE of San Rafael,

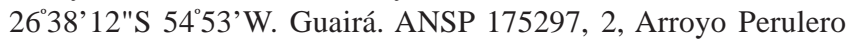
where it crosses road from Villarrica, 2551'53"S 56 24 '40"W. ANSP 175301, 16, stream crossing road that runs through Parque Nacional Guayaquil. Tebicuary - Paraná drainage, 2541’1"S 56¹8’31"W. Misiones. ANSP 175302, 17, stock pond by road from San Ignacio to Pilar, 26 $6^{\circ} 52^{\prime} 51^{\prime \prime S} 57^{\circ} 3^{\prime} 5^{\prime \prime W}$. ANSP 175303, 62, pool in stream crossing Asunción - Encarnación highway, 2653’24"S 5653’47"W. Rio Paranaíba Drainage: BRAZIL. Distrito Federal. MNRJ 19986, 9, Brasília, BR-020, N exit from Brasília, close to bridge on road to Sobradinho, near Parque Nacional de Brasília. Minas Gerais. MCP 27374, Abadia dos Dourados, rio Preto, road from Palmito to Abadia dos Dourados, $18^{\circ} 6^{\prime} 15^{\prime \prime S} 47^{\circ} 41^{\prime} 35^{\prime \prime} W$. Rio Grande Drainage: BRAZIL. Minas Gerais. MCP 18134, 3, Carandaí, rio Carandaí upstream Carandaí. MCP 23498, 6, Delfim Moreira, rio Santo Antonio, affluent to rio Sapucaí. MCP 23501, 6, Cristina, rio Lambari, affluent to rio Verde. MCP 23515, 6, Poços de Caldas, ribeirão Cipó affluent to rio das Antas. MCP 23516, 6, Aiuruoca. rio
Aiuruoca. MZUSP 35406, 28, Fortaleza de Minas, rio São João. São Paulo. MCP 27014, 12, Itirapina, Represa do Lobo, mouth to the rio Itaqueri. MZUSP 49231, 40 of 82, Cajuru, unnamed creek at Fazenda Santa Carlota. Rio Tietê Drainage: BRAZIL. São Paulo. MCP 20582, 35, Buritiba Mirim, first road from Biritiba Mirim to Casa Grande. MCP 20586, 22, Salesópolis, creek Paraitinguinha on road Salesópolis to Jacareí, 3 km N from Salesópolis. MCP 25526, 8, Biritiba Mirim, creek on road from Biritiba Mirim to Casa Grande, affluent to Barragem Ponte Nova at rio Tietê. MCP 27375, 1, Piracicaba, ribeirão Vermelho, road Piracicaba - Anhembi, ca. 14 km from Piracicaba, 22 42'59"S 4743’27"W. MCP 28686, 3, Paranapiacaba, creek ca. 2 km NW from Paranapiacaba, on road from Campo Grande to Paranapiacaba, 2346’21"S 4618’52"W. MZUSP 35345, 20 of 70, Bofete, ribeirão Água Fria. MZUSP 45486, 11, Campinas, creek affluent to rio Atibaia, estrada da Fortuna near Rodovia D. Pedro I. MZUSP 49467, 20 of 35, Araçariguama, creek affluent to ribeirão Araçariguama, at the Mineração Morro Grande. NRM 43501, 8, road to Barbosa, 5 km from road SP-153, second creek, above bridge. Rio Paranapanema Drainage: BRAZIL. Paraná. MCP 12583, 8, Jaguariaíva, rio Capivari under bridge on road PR-92. MCP 27007, 13, Ponta Grossa, rio Verde. Rio Iguaçu Drainage: BRAZIL. Paraná. MCP 22274, 11, Paulo Frontin, arroio Barra Grande on road BR 153, 2559’42"S 5052’0"W. MCP 22275 , 2, Cruzeiro do Iguaçu, beach at Represa Salto Caxias at Foz do Chopim, 25³4'5"S 537'22"W. MCP 22276, 1, Catanduvas, sanga Feijão, affluent to rio Adelaide, 2515'25"S 53ㅇ'30"W. MCP 22277 , 4, Pérola do Oeste, creek on road BR 163, between Planalto and Pérola do Oeste, 25 43’44"S 5347’9"W. MCP 27006, 5, Piraquara, Cavas do Piraquara. MCP 27013, 17, Curitiba, Fazenda Canguiri. MCP 27018, 89, Faxinal do Céu, creek affluent to rio Iguaçu. MHNCI 9065, 6, Araucária, Guajuvira, Chácara Kotowski, PR 423. USNM 297981, 9, headwaters of rio Iguaçu, near Serrinha (road BR 476 between Lapa and Contenda). USNM 304995, 8, ribeirão Amola-Faca, tributary to rio Iguaçu, near Balsa N. in Fazenda Lara Maria. Santa Catarina. USNM 320323, 3, rio Negrinho, under bridge on road BR 280, rio Negrinho. Coastal drainages (from north ro south). Rio Itaboapana Drainage. BRAZIL. Espírito Santo. MCP 17839, 2, rio São José das Torres near road BR-101, between São José das Torres and Travessão, 214ㄴ3"S 41¹4’2"W. Rio Paraíba 
do Sul Drainage: BRAZIL. Rio de Janeiro. MNRJ 14424, 34, Teresópolis, ribeirão Santa Rita (tributary to the left margin of rio Paquequer), near Fazenda Santo Afonso. MNRJ 15312, 7, Carmo, córrego Astréia near Astréia. MNRJ 15539, 7, Sumidouro, rio Paquequer, upstream Sumidouro. USNM 257030, 72, rio dos Coitinhos at km 55 on road RJ 155, headwater tributary to rio Piraí, near road RJ 155 between Angra dos Reis and Rio Claro, 2251'20"S 441'30"W. São Paulo. MCP 18132, 6, Piquete, creek affluent to rio Piquete at Benfica. 22 35’46"S 4513’6"W. MCP 20570, 3, Arapeí, small tributary to rio Bananal, ca. 6 km NE from Arapeí, on road from Arapeí to Santana do Bom Sucesso (SP 66), 2240’32"S 44²4’36"W. MCP 20575, 3, São José do Barreiro, rio Água Santa, 22³8’40"S 44³4’31"W. MCP 20584, 7, Taubaté, córrego Itaí on road Taubaté - São Luís Paraitinga, ca. 5 km S from Taubaté 234'17"S 45³3’20"W. MCP 20587, 17, São Luís Paraitinga, ribeirão do Pinga tributary to ribeirão do Chapéu at Catuçaba, 2314’37"S 45¹2’32"W. MCP 20588, 27, Silveiras, córrego Macaquinho, tributary to rio Paraitinga, ca. 5 km NW from Bairro dos Macacos, 2250’47"S 445’30"W. MCP 27015, 9, Paraibuna, rio Paraíba do Sul. MZUSP 47189, 27, Cunha, Serra dos Macacos, riacho do Macaquinho, near Sítio do Sr. Jair Romão. MZUSP 47193, 21 of 30, Mogi das Cruzes, Cachoeirinha do Angico, Sítio do Sr. Manuel Figueiredo, Bairro de Itapeti. MZUSP 47202, 27, Santa Isabel, headwaters of rio Piläes, Sítio Bem Viver. MZUSP 47582, 9, Pindamonhangaba, ribeirão Grande, talhão 1, near Sede of Fazenda São Sebastião do Ribeirão Grande. USNM 309782, 56, stream about halfway between Santa Branca and Salesópolis. Rio Macaé Drainage: BRAZIL. Rio de Janeiro. MCP 18133, 2, rio Macaé on road from Casemiro de Abreu to Lumiar, ca. 5 km E from Lumiar. MCP 20566, 7, Macaé, rio dos Frades at Frades, 2214'34"S 426’18"W. Rio Macacu Drainage: BRAZIL. Rio de Janeiro. USNM 309773, 3, rio Macacu near Cachoeiras de Macacu, small tributary ca. 1-2 km from town, highway bridge over stream, collected near and under bridge. Lagoa de Saquarema Drainage: BRAZIL. Rio de Janeiro. USNM 257028, 33, rio Seco, tributary to lagoa de Saquarema along road Amaral Peixoto between Sampaio Correia and Bacaxa on map. locality is at bridge. USNM 257029, 15, rio do Mato Grosso, tributary to rio Roncador which flows into lago de Saquarema. Rio São João Drainage: BRAZIL. Rio de Janeiro. MCP 20565, 9, Silva Jardim, rio Iguapé near road BR 101, ca. 14 Km SE from Casemiro de Abreu, 22³0'58"S 42¹9'20"W. Baía de Guanabara System: BRAZIL. Rio de Janeiro. MZUSP 43471, 20 of 32, Rio de Janeiro, Floresta da Tijuca. USNM 309784, 21, km 27 on road Amaral - Peixoto, about 1 km from Itapeba in small tributary to rio Fundo, near Maricá. MNRJ 15133, 1, Magé, road to Santo Aleixo, rio Santo Aleixo tributary to rio Roncador near Santo Aleixo, 22³5’ 23"S 432'45"W. Rio Mato Grosso-Roncador System. UNT 6768, 10, Saquarema, rio Mato Grosso, 2253’12"S 42³9’54"W. Rio Tavares Drainage: BRAZIL. São Paulo. USNM 257037, 51, southern branch of rio Tavares, Ubatuba system at nursery of "flora Brazilia”. Rio Escuro Drainage: BRAZIL. São Paulo. USNM 257027, 17, rio Escuro. Rio Juqueí Drainage: BRAZIL. São Paulo. MZUSP 49936, 11, São Sebastião, Praia de Juqueí, stream affluent to rio Juqueí. Ilha Bela: MCP 31131, 317, Ilha Bela, stream in the road to Praia dos Castelhanos, $1.5 \mathrm{~km}$ from Ilha Bela, 2349'30"S 45²1’48"W. Rio Cabuçu Drainage: BRAZIL. São Paulo. NRM 43502, 4, Baixada Santista, unpaved from road Santos to Rio de Janeiro, tributary creek of the rio Cabuçu. Other small coastal drainages in São Paulo State: MCP 30999, 58, Barra do Turvo, rio Bonito, affluent to rio Pardo, Bairro Rio Bo-

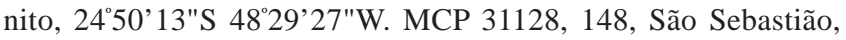
córrego da Barra, 234’’22"S 45³3’7"W. MCP 31144, 64, Peruíbe,

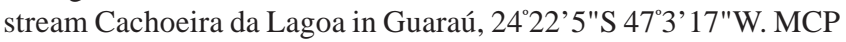

31186, 11, Mongaguá, lateral pond ca. 3 km from road SP 55,

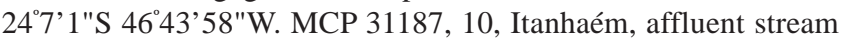
to rio Preto ou Branco ca. $2 \mathrm{~km}$ from state airport $24^{\circ} 8^{\prime} 37^{\prime \prime S}$ 4646’34"W. MCP 31622, 155, Caraguatatuba, creek on Praia de Massaguaçú, ca. $700 \mathrm{~m} \mathrm{~W}$ of road SP 55, 2334'23"S 45¹9'38"W. MCP 31623, 185, Santos, creek at Carnaíra ca. $100 \mathrm{~m}$ from road SP 55, at border Bertioga - Santos, 2352’56"S 46¹1’29"W.

Diagnosis. Phalloceros harpagos can be distinguished from $P$. anisophallos, $P$. megapolos, $P$. spiloura, $P$. reisi, $P$. buckupi, P. alessandrae, P. lucenorum, P. uai, P. pellos, and $P$. malabarbai by the female urogenital papilla straight along midline and located between the anus and the base of first anal-fin ray ( $v s$. curved to the right, located laterally; border of the anal aperture in contact with the first anal-fin ray). Phalloceros harpagos can be distinguished from $P$. tupinamba, $P$. leptokeras, and $P$. aspilos by (1) the female urogenital papilla straight along midline (vs. slightly left turned); (2) absence of a lateral ramus of the female urogenital papilla (vs. lateral ramus present); and (3) small and simple hook in gonopodial appendix (vs. large sickle like hook). Phalloceros harpagos can be distinguished from $P$. caudimaculatus, $P$. heptaktinos, P. ocellatus, $P$. mikrommatos, and $P$. leticiae by the possession of a hook in the gonopodial appendix (vs. hook absent). Phalloceros harpagos can be distinguished from $P$. titthos by the absence of symphyseal papillae on large females (vs. symphyseal papillae present); and from $P$. enneaktinos by the possession of seven or eight dorsal-fin rays (vs. nine) (see remarks). Phalloceros harpagos can be distinguished from $P$. elachistos by the hook of gonopodial appendix not forming a lateral protuberance ( $v s$. very small in adults, forming a lateral minute protuberance - see remarks). In juveniles hook present and located on the appendix corner (vs. absent or (rarely) minuscule, when present in juveniles hook never situated on the appendix corner). Skin present covering the tip of appendix on juveniles (vs. skin absent). Distal half of appendix narrower than proximal half (vs. approximately as wide as or slightly narrower than proximal half).

Description. Morphometric data in Tables 9 and 10. Range of SL: 18.4 to $46.8 \mathrm{~mm}$ (females), 14.8 to $34.1 \mathrm{~mm}$ (males). Dorsalfin rays: 7 [15], 8* [639], 9 [21]. Branched pectoral-fin rays: 5 [3], 6 [245], $7 *$ [273], 8 [5]. Pelvic-fin rays: 5* [203] (males), 4 [2], 5 [450] (females). Anal-fin rays of females: 10 [85], 11 [349], 12 [1, incomplete]. Anal-fin rays of males: 8 [4], 9* [221], 10 [21]. Branched caudal-fin rays: 8 [1], 10 [13], 11 [118], 12* [375], 13 [89], 14 [17], 15 [1], 16 [1]. Predorsal scales: 12 [3], 13 [49], 14* [368], 15 [32]. Longitudinal series of scales: 27 [22], 28 [196], 29* [444], 30 [35]. Series of scales around caudal peduncle: 14 [5], 15 [2], 16* [688].Transverse series of scales: $7 *$ [562]. Serrae on R4p: 8 [8], 9 [27], 10 [76], 11 [42], 12 [36], 13 [31], 14* [11], 15 [5], 16 [1]. Epipleural ribs: 11 [2], 13 [2]. Pleural ribs: 14 [2], 15 [2]. Vertebrae: 31 [1], 32 [2], 33 [1]. Female urogenital papilla straight, located along midventral line and between anus and base of first anal-fin ray. Gonopodial ap- 
pendix hook present (Fig. 28). Hook present in juveniles and located on appendix corner. Juveniles bearing skin covering tip of appendix. Distal half of appendix narrower than proximal half (Fig. 28).

Color in alcohol. Eye black with greenish brown pupil. Ground Color brown, darker in upper half. Border of scales and subjacent skin replete with brown chromatophores, more concentrated at short distance from scale border, conferring reticulate pattern to body sides, mainly on upper half. Brown chromatophores scattered through whole body, more concentrated on dorsal portion, mainly on head, snout, opercle, and ventral surface of mandible. Lateral dark brown spot located between $16^{\text {th }}$ and $19^{\text {th }}$ scale of longitudinal series. Dorsal-fin membrane hyaline bearing dark band of chromatophores on distal border of dorsal fin and another near dorsal-fin base. Pectoral, pelvic, and caudal fins hyaline. Dark brown line along R3. First three anal-fin rays of females covered of brown chromatophores forming patch of dark pigmentation.

Intraspecific Variability. Variation in some morphological features (e.g. color pattern, hook on gonopodial appendix, measurements) has been found among distinct populations of $P$. harpagos during this revisionary study. Although differences may be found between some population pairs, it has not been possible to assign any of them as diagnostically distinct from the remaining populations. So, these populations are referred to as the same species.

Degree of development of spots varies enormously, ranging from large and wide dark patch through small and narrow spot to no apparent mark. Variation on color cannot be associated as exclusive of any local population, for all variants are generally present in any of the populations. Alternatively the frequencies of each of the color "types" can be correlated to populations.

Specimens from coastal drainages of Rio de Janeiro and

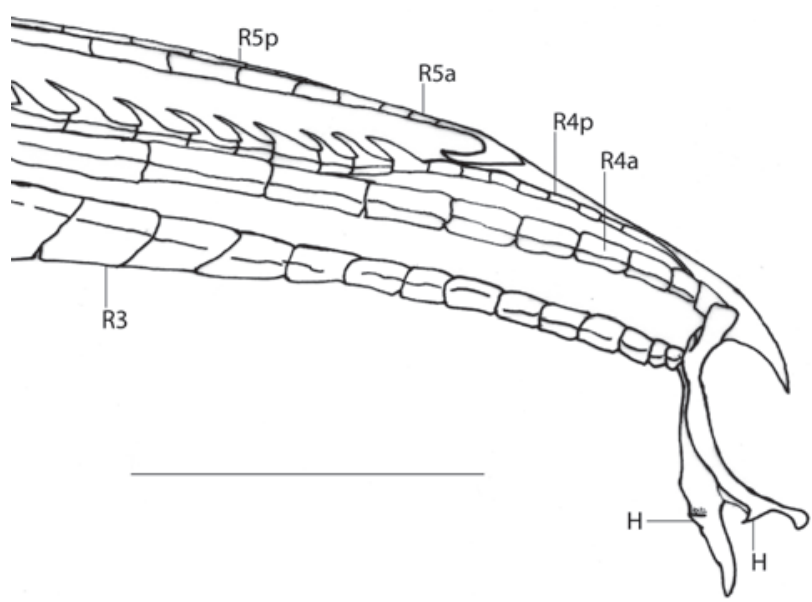

Fig. 28. Gonopodium tip of Phalloceros harpagos, MCP 20569. R3, R4a, R4p, R5a, R5p indicate gonopodial rays. Scale bar 1 $\mathrm{mm}$.
São Paulo usually possess a roundish and short lateral spot, whereas southern populations in Santa Catarina usually show an elongate and wide lateral spot reaching dorsal and ventral profiles. Generally, specimens from the rio Paraná drainage possess a narrow and vertically elongate spot not reaching dorsal and ventral profiles. Individuals from some populations, e.g. rio Ribeira do Iguape, rio Iguaçu, present a very narrow and short lateral spot.

Particularly, the population in the rio Ribeira de Iguape is an interesting case. This river is formed by the junction of rio Ribeira and rio Juquiá. Specimens from the rio Ribeira have a very narrow and short lateral spot, while specimens from the rio Juquiá possess a large and wide lateral spot. They are quite different from each other. Despite this, none of them can be distinguished from the bulk of $P$. harpagos, i.e. each can not be diagnosed or recognized as a distinctive species.

Similarly, some specimens of the lower portions of rio Paraná differ from specimens from rio Paraguay. The former show narrow and vertically elongate lateral spot, whereas the later show large and roundish lateral spot. The two forms occur in the lower rio Paraná. This difference is congruent with differences in the depth of body and caudal peduncle of males. Again, both are clearly different from each other but cannot be distinguished from populations along the range of $P$. harpagos as a whole.

Degree of development of the hook in the gonopodial appendix may also vary from a large hook to lateral expansion, especially in specimens from coastal drainages in southern Santa Catarina, which usually present a shorter hook on gonopodial appendix.

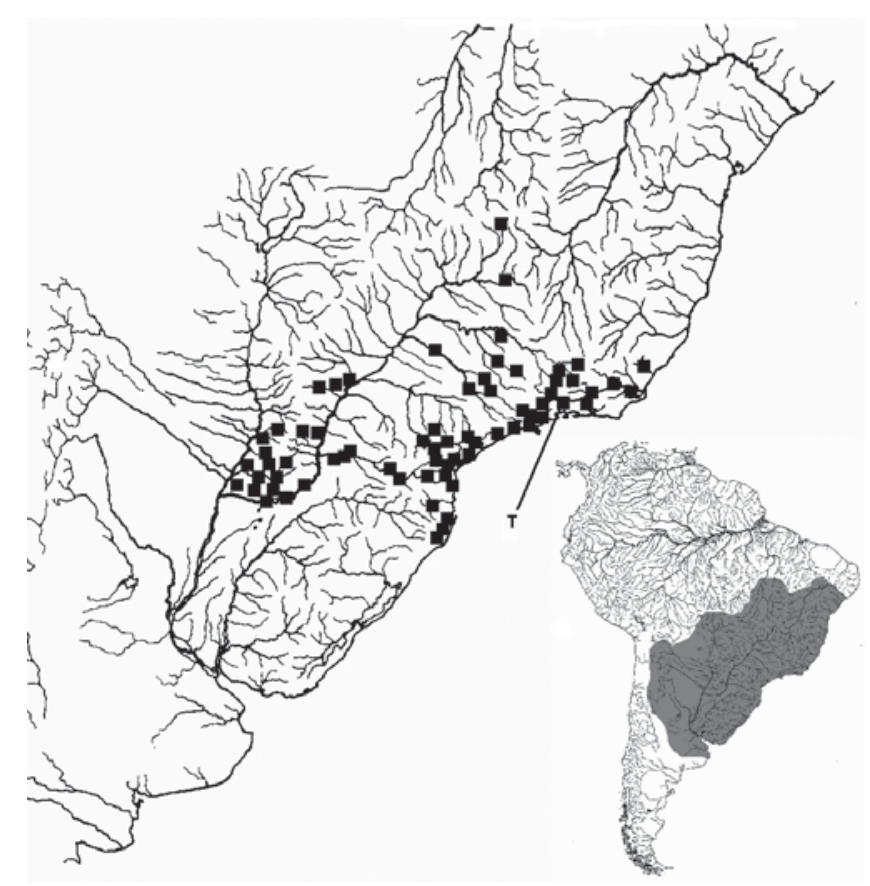

Fig. 29. Collection localities of Phalloceros harpagos. Some symbols represent more than one lot or locality. T represents type locality. The inset is the range of the genus. 


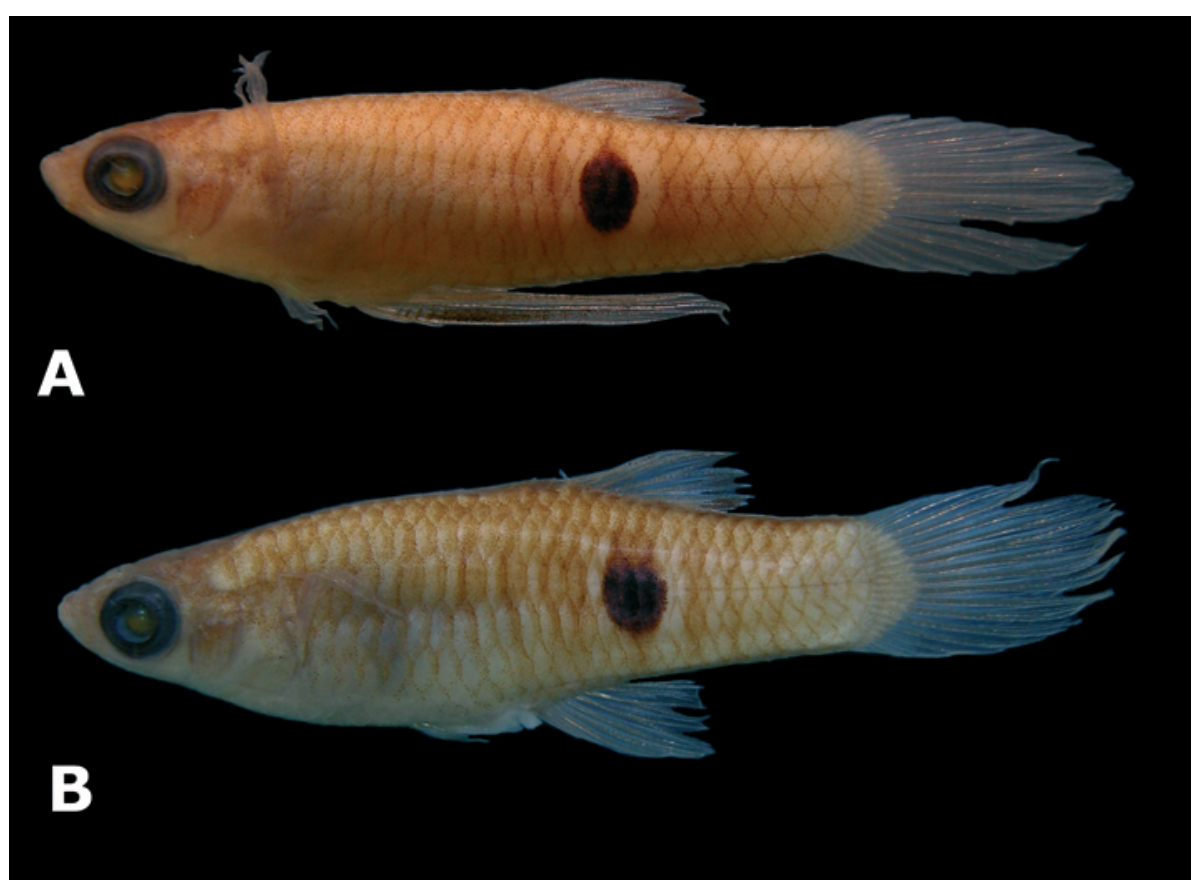

Fig. 30. Phalloceros ocellatus. (A) Holotype, male, $16.3 \mathrm{~mm}$ SL, MCP 30549, fourth stream flowing east at $26 \mathrm{~km}$ from Prado on road from Prado to Cumuruxatiba. Prado, Bahia, Brazil; (B) paratype, female, MCP 30548, 24.4 mm SL, collected with the holotype.

At the moment, it is advisable to treat these differences as intraspecific variation, unless new evidences become available and allow the recognition of new diagnosable taxonomic entities.

Etymology. From the Greek ' $\alpha \rho \pi \alpha \gamma o s$ [= harpagos], n. m. nom. sg., meaning hook, alluding the presence of a hook in the gonopodial appendix. An noun in apposition.

Distribution. Rio Paraná-Paraguay basin and coastal drainages from rio Itaboapana (ES) to rio Araranguá (SC) (Fig. 29).

\section{Phalloceros ocellatus, new species}

Figs. 30, 31

Phalloceros sp. n. B Lucinda \& Reis (2005).

Holotype. MCP 30549, fourth stream flowing east at $26 \mathrm{~km}$ from Prado on road from Prado to Cumuruxatiba, approximately $17^{\circ} 10^{\prime} \mathrm{S}$ 39¹4’W, Prado, Bahia, Brazil, 19 Mar 1985, Expedition MZUSP/ USNM.

Paratypes. BRAZIL. Bahia. MCP 30548, 14/4*, MZUSP 39121, 25, and USNM 331088, 39, collected with the holotype. USNM 331086, 4, NE of Curumuxatiba, streamlet near Fazenda Embaúba, probably tributary to Ibarube on SE 24, 20 Mar 1985, N.A. Menezes et al. Espírito Santo. MCP 17838, 3, São Gabriel da Palha, creek at km 118 on road BR 101, near the Reserva Florestal de Sooretama, 20 Jan 1995, W.G. Saul, A.S. Santos \& J.C. Garavello.

Diagnosis. Phalloceros ocellatus can be distinguished from its congeners but $P$. leticiae and $P$. mikrommatos by the roundish to rounded and well-defined ocellated lateral spot (Fig. 30). Phalloceros ocellatus can be distinguished from $P$. leticiae by the postorbital length in females (24.8-39.3\% SL vs. 39.2-42.2 \% SL, respectively) and in males (29.3-38.2 \% SL vs. 36.7-42.3\% SL, respectively). Phalloceros ocellatus can be distinguished from P. mikrommatos by the number of anal-fin rays in females (10 vs. 11, respectively).

Description. Morphometric data in Tables 11 and 12. Range of SL: 17.7 to $25.2 \mathrm{~mm}$ (females), 15.4 to $18.5 \mathrm{~mm}$ (males). Dorsal-fin rays: 7 [3], 8* [29]. Branched pectoral-fin rays: 5 [1], 6* [16], 7 [2]. Pelvic-fin rays: 5* [10] (males), 5 [22] (females). Anal-fin rays of females: 9 [1], 10 [22]. Anal-fin rays of males: 9 [11]. Branched caudal-fin rays: 9* [13], 10 [14], 11 [5]. Predorsal scales: 13 [3], 14* [21], 15 [2]. Longitudinal series of scales: 27 [7], 28 [19], 29* [7]. Series of scales around caudal peduncle: $16^{*}$ [34]. Transverse series of scales: $7 *$ [34]. Serrae on R4p: 10* [2], 11 [5], 12 [3], 13 [1]. Epipleural ribs: 12 [4]. Pleural ribs: 14 [2]. Vertebrae: 31 [1], 32 [3]. Female urogenital papilla straight along midline, located along midventral line and between anus and base of first anal-fin ray. Hooks of gonopodial appendix absent (Fig. 31).

Color in alcohol. Eye dark iridescent grey with greenish brown pupil. Ground color pale yellow. Upper two thirds of body and head densely covered with brown chromatophores. In some individuals these chromatophores more concentrated on longitudinal line region forming faint brown discontinuous band along flanks. Lower third of flanks pale yellow contrasting with upper, darker region. Border of scales and subjacent skin replete with brown chromatophores, more con- 


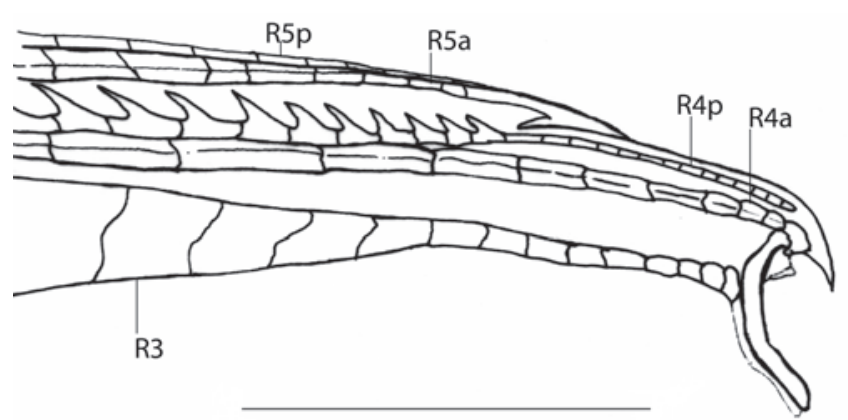

Fig. 31. Gonopodium tip of Phalloceros ocellatus, MCP 39121. R3, R4a, R4p, R5a, R5p indicate gonopodial rays. Scale bar $1 \mathrm{~mm}$.

centrated at short distance from scale border conferring reticulate pattern to body sides, mainly on upper half. Brown chromatophores scattered through whole body, more concentrated on dorsal portion, mainly on head, snout, opercle, and ventral surface of mandible. Ocellated lateral spot rounded or roundish encircled by light ring. Vertical bars along flanks inconspicuous or absent. Dorsal-fin membrane bearing faint band of brown chromatophores on distal border of dorsal fin. Faint band of chromatophores near dorsal-fin base. Pectoral, pelvic, and caudal fins hyaline. Dark brown line along R3. Anal fin of females hyaline; few chromatophores scattered through first three rays but not forming defined patch of pigmentation.

Etymology. The noun ocellatus (-a, -um) is a Latin adj. (m. nom. sg.), meaning with little eyes, from ocellus, diminutive of oculus, eye, alluding to the lateral spot, which is rounded and has an external light ring. An adjective.

Distribution. Phalloceros ocellatus is distributed in coastal drainages of Bahia and Espírito Santo States between Prado and Sooretama (Fig. 12).

Phalloceros alessandrae $+P$. malabarbai $+P$. megapolos + P. lucenorum + P. uai + P. buckupi + P. anisophallos + P. pellos $+P$. spiloura $+P$. reisi

Clade 76, Lucinda \& Reis (2005).

Diagnosis. Members of this clade share the following uniquely derived and unreversed feature: female urogenital papilla turned to the right [142-1**].

\section{Phalloceros alessandrae + P. malabarbai + P. megapolos Clade 75, Lucinda \& Reis (2005).}

Diagnosis. Members of this clade share the following uniquely derived and unreversed feature: hooks large directed downward and located in the corner of gonopodial appendix [97-1**].

\section{Phalloceros alessandrae, new species}

Figs. 32, 33

Phalloceros sp. n. N Lucinda \& Reis (2005).

Holotype. MCP 30402, flooded areas on margins of road PR 340, approximately 2526'S 4843’W, Antonina, Paraná, Brazil, 11 Dec 1991, E. Grando Jr. \& A.A.M. Cordeiro.

Paratypes. BRAZIL. Paraná. MCP 25561, 3/1*, collected with the holotype. MCP 27005, 2/1*, Antonina, rio Dois de Fevereiro, 2518’33"S 4844’32"W, Jul 1994, F. Popazoglo.

Diagnosis. Phalloceros alessandrae can be distinguished from its congeners but $P$. megapolos, $P$. spiloura, $P$. malabarbai, P. anisophallos, P. buckupi, P. uai, P. lucenorum, $P$. pellos, and $P$. reisi by (1) the female urogenital papilla curved to the right, located laterally [142-1] (vs. slightly left turned and with a lateral ramus [142-2] or straight located along midventral line [142-0]); and (2) border of the anal aperture in contact with the first anal-fin ray or very close to it (vs. separated from first anal-fin ray by the female urogenital papilla).

Phalloceros alessandrae can be distinguished from $P$. megapolos by the gonopodial appendix normally developed (vs. greatly expanded in wing like expansions); and from $P$. spiloura, $P$. anisophallos, $P$. buckupi, $P$. uai, $P$. lucenorum, $P$. pellos, and $P$. reisi by (1) the halves of gonopodial paired appendix slender, not sickle like, and similar to each other (vs. sickle like and different from each other), bearing a medial corner (vs. medial corner absent); and (2) hooks on both halves of gonopodial paired appendix (vs. right half hook absent). Phalloceros alessandrae can be distinguished from $P$. malabarbai by (1) gonopodial appendix straight at the distal tip (vs. strongly arched at the distal tip); (2) distal portion straight and oblique forming a $45^{\circ}$ angle with the vertical axis (vs. distal portion bent upward); and (3) left and right halves coalescent at the base (vs. halves free not coalescent at the base) (Fig. 33).

Description. Morphometric data in Tables 5 and 6. Range of SL: 22.1 to $24.7 \mathrm{~mm}$ (females), $17.5 \mathrm{~mm}$ (male). Dorsal-fin rays: 8* [6]. Branched pectoral-fin rays: 6 [1], 7* [1]. Pelvic-fin rays: 5* [2] (males), 5 [4] (females). Anal-fin rays of females: 10 [2], 11 [2]. Anal-fin rays of males: 9* [2]. Branched caudal-fin rays: $10 *$ [1], 11 [4], 12 [1]. Predorsal scales: $14 *$ [2], 15 [2]. Longitudinal series of scales: 28 [1], 29* [4], 30 [1]. Series of scales around caudal peduncle: $16^{*}[6]$. Transverse series of scales: $7 *$ [6]. Serrae on R4p: 10* [1], 11 [1]. Vertebrae: 32 [1]. Female urogenital papilla right curved, located laterally. Border of anal aperture in contact with first anal-fin ray or very close to it. Halves of gonopodial paired appendix slender, not sickle like, and similar to each other, bearing medial corner. Hook on both halves of gonopodial paired appendix. Hooks large downward directed and located at corner of gonopodial appendix. Gonopodial appendix long and straight at distal tip. Distal portion straight and oblique forming $45^{\circ}$ angle with vertical axis. Left and right halves coalescent at base (Fig. 33) 


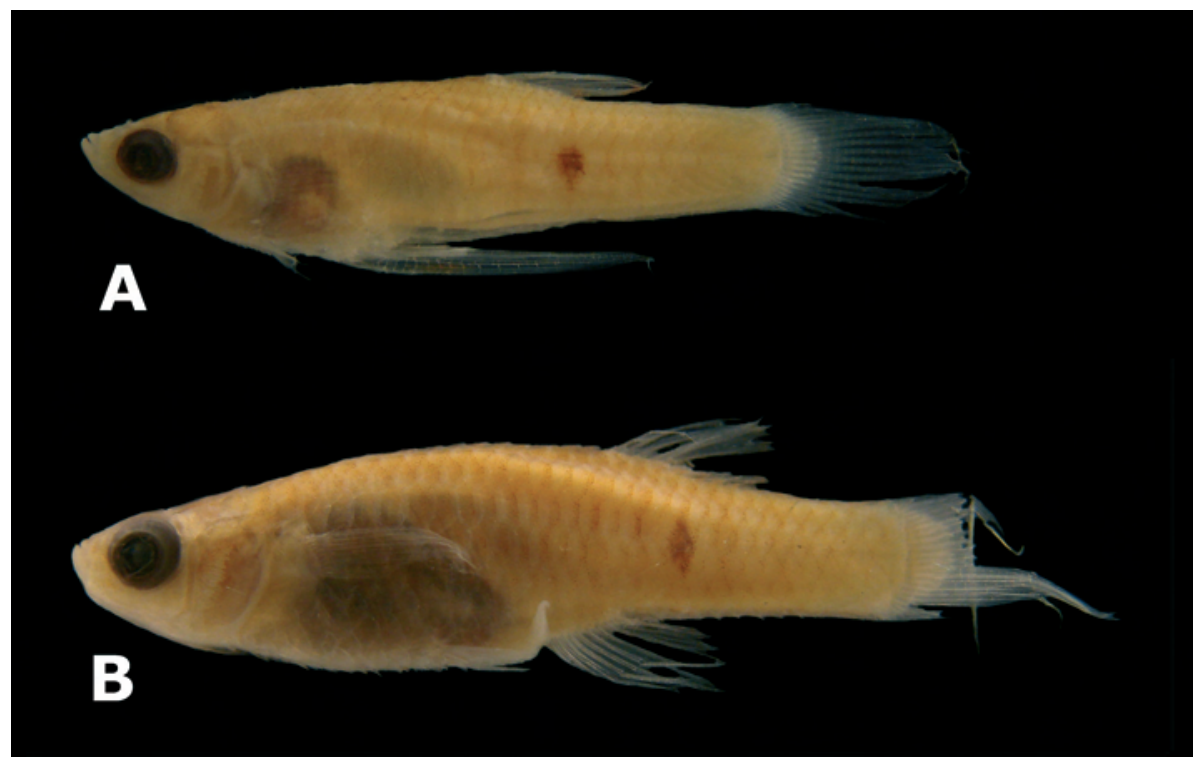

Fig. 32. Phalloceros alessandrae. (A) Holotype, male, 17.5 mm SL, MCP 30402, flooded areas on margins of road PR 340, Antonina, Paraná, Brazil; (B) paratype, female, MCP 25561, 22.1 mm SL, collected with the holotype.

Color in alcohol. Eye silvery grey with greenish brown pupil. Ground color pale brown, darker in upper half. Border of scales and subjacent skin replete with brown chromatophores, more concentrated at short distance from scale border, conferring reticulate pattern to body sides, mainly on upper half. Brown chromatophores scattered through whole body, more concentrated on dorsal portion, mainly on head, snout, opercle, and ventral surface of mandible. Lateral dark brown spot located between $17^{\text {th }}$ and $19^{\text {th }}$ scale of longitudinal series. Lateral spot corresponding approximately in size to one scale. Light brown bars along flanks inconspicuous or absent. Dorsal-fin membrane bearing dark band of chromatophores on distal border of dorsal fin. Dark band of chromatophores near dorsal-fin base. Pectoral, pelvic, and caudal fins hyaline. Dark brown line along R3.

Etymology. The specific epithet alessandrae (n. f. gen. sg.) comes from Alessandra. Phalloceros alessandrae is named after my wife Alessandra M. V. Lucinda.

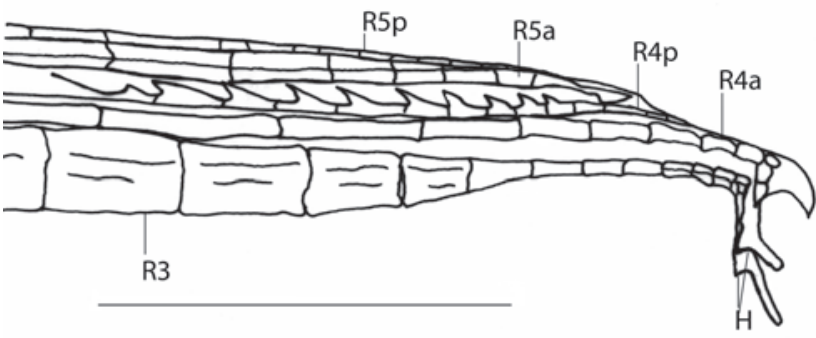

Fig. 33. Gonopodium tip of Phalloceros alessandrae, MCP 30402. R3, R4a, R4p, R5a, R5p indicate gonopodial rays. Scale bar $1 \mathrm{~mm}$.
Distribution. Phalloceros alessandrae is known from flooded areas on margins nearby Antonina (Paraná, Brazil) and rio Dois de Fevereiro, which flows into the Baía de Paranaguá (Fig. 18).

\section{Phalloceros malabarbai, new species} Figs. 34, 35

Phalloceros sp. n. R Lucinda \& Reis (2005).

Holotype. MZUSP 79669, creek near Itapoá, approximately 26ำ' 'S 48 38'W, São Francisco do Sul, Santa Catarina, Brazil, 22 Dec 1985, W. J. E. M. Costa.

Paratypes. BRAZIL. Santa Catarina. MZUSP 35422, 7/2*, collected with the holotype.

Diagnosis. Phalloceros malabarbai can be autapomorphically diagnosed by functional gonapophyses on vertebrae 15, 16, and 17 [49-3*]. Additionally, P. malabarbai can be distinguished from its congeners by the width of first pelvic-fin ray in adult males approximately constant tapering gradually to tip. Phalloceros malabarbai can be distinguished from its congeners but $P$. megapolos, $P$. spiloura, $P$. anisophallos, P. alessandrae, P. buckupi, P. uai, P. lucenorum, $P$. pellos, and $P$. reisi by (1) the female urogenital papilla curved to the right, located laterally (vs. slightly left turned and with a lateral ramus or straight located along midventral line) and (2) border of the anal aperture in contact with the first anal-fin ray or very close to it (vs. separated from first anal-fin ray by the female urogenital papilla).

Phalloceros malabarbai can be distinguished from $P$. megapolos by the gonopodial appendix normally developed (vs. greatly expanded in wing like expansions); and from $P$. spiloura, P. anisophallos, P. buckupi, P. uai, P. lucenorum, $P$. pellos, and $P$. reisi by (1) the halves of gonopodial paired 


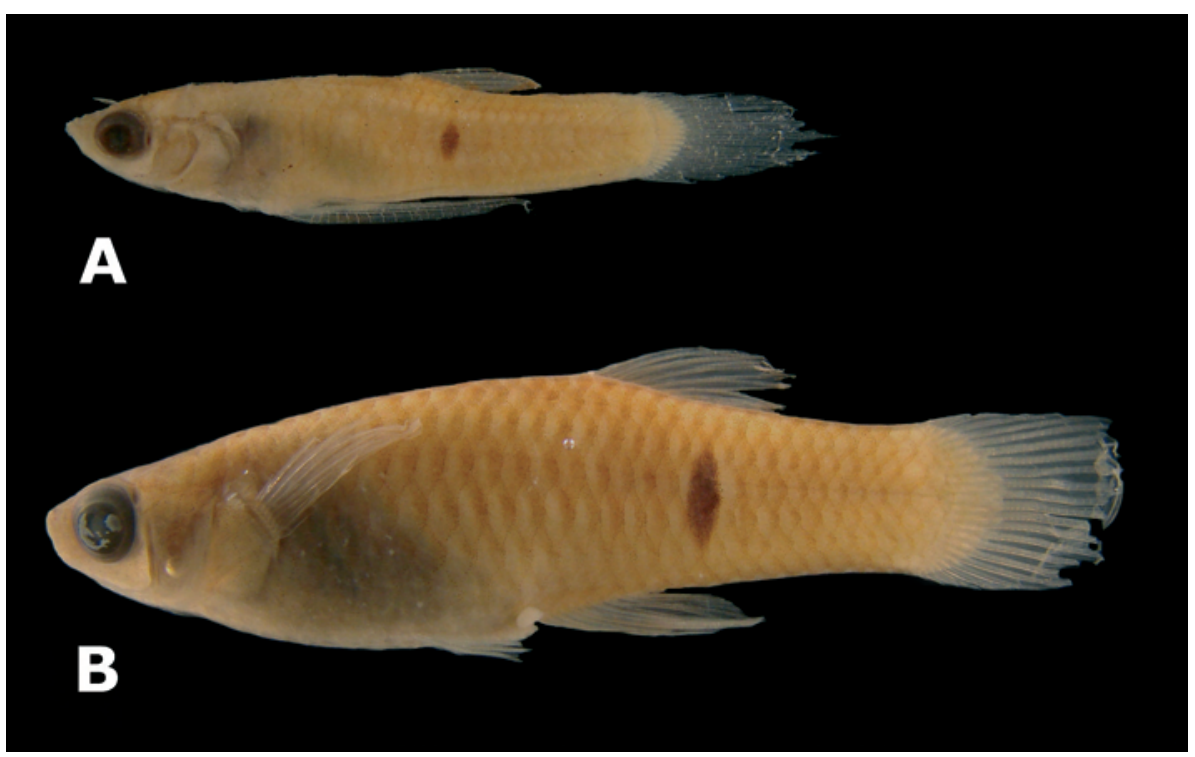

Fig. 34. Phalloceros malabarbai. (A) Holotype, male, 34.1 mm SL, MZUSP 79669, Itapoá, Santa Catarina, Brazil; (B) paratype, female, MZUSP 35422, $32.1 \mathrm{~mm}$ SL, collected with the holotype.

appendix slender, not sickle like, and similar to each other ( $v s$. sickle like and different from each other), bearing a medial corner (vs. medial corner absent); and (2) hooks on both halves of gonopodial paired appendix (vs. right half hook absent).

Phalloceros malabarbai can be distinguished from $P$. alessandrae by (1) gonopodial appendix strongly arched at the distal tip (vs. straight at the distal tip); (2) distal portion bent upward (vs. distal portion straight and oblique forming a $45^{\circ}$ angle with the vertical axis); and (3) left and right halves free not coalescent at the base (vs. coalescent at the base).

Description. Morphometric data in Tables 3 and 4. Range of SL: 31.4 to $32.1 \mathrm{~mm}$ (females), $22.2 \mathrm{~mm}$ (male). Dorsal-fin rays: 8* [4]. Branched pectoral-fin rays: 6 [1]. Pelvic-fin rays: $5^{*}$ [1] (male), 4 [1], 5 [2] (females). Anal-fin rays of females: 11 [3]. Anal-fin rays of males: $9 *$ [1]. Branched caudal-fin rays: $10 *$ [1], 13 [1]. Predorsal scales: 14* [4]. Longitudinal series of scales: 28 [3], 30* [1]. Series of scales around caudal peduncle: 16* [4]. Transverse series of scales: $7 *$ [4]. Serrae on R4p: $10 *$ [1]. Epipleural ribs: 13 [1], 14 [1]. Pleural ribs: 14 [1], 15 [1]. Vertebrae: 32 [1], 33 [1]. Female urogenital papilla right curved, located laterally. Border of anal aperture in contact with first anal-fin ray or very close to it. Halves of gonopodial paired appendix slender, not sickle like, and similar to each other, bearing medial corner. Hook on both halves of gonopodial paired appendix. Hooks large downward directed and located at corner of gonopodial appendix. Gonopodial appendix long and strongly arched at distal tip. Distal portion bent upward. Left and right halves free not coalescent at base (Fig. 35).

Color in alcohol. Eye black with greenish brown pupil. Ground color cream, darker in upper half. Border of scales and subjacent skin replete with brown chromatophores, more concentrated at short distance from scale border, conferring reticu-

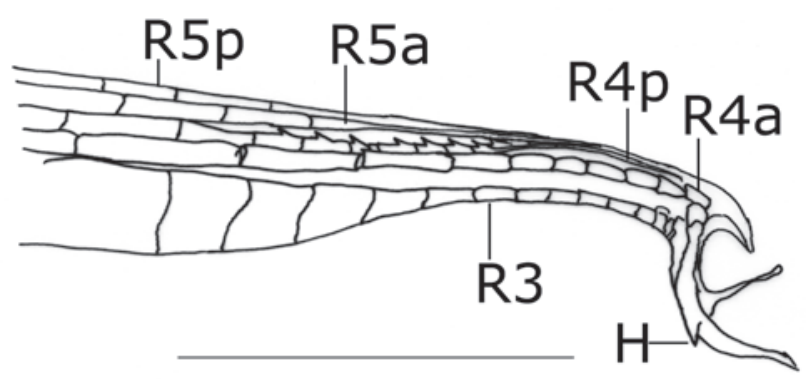

Fig. 35. Gonopodium tip of Phalloceros malabarbai, holotype, MZUSP 79669. R3, R4a, R4p, R5a, R5p indicate gonopodial rays. $\mathrm{H}=$ hook. Scale bar $1 \mathrm{~mm}$.

late pattern to body sides, mainly on upper half. Brown chromatophores scattered through whole body, more concentrated on dorsal portion, mainly on head, snout, opercle, and ventral surface of mandible. Lateral dark brown spot located over $17^{\text {th }}$ and $18^{\text {th }}$ scale of longitudinal series. Lateral spot covering approximately two scales on horizontal direction, and four scales on vertical. Dorsal-fin membrane hyaline bearing faint. band of brown chromatophores on distal border of dorsal fin and another near dorsal-fin base. Pectoral, pelvic, and caudal fins hyaline. Dark brown line along R3.

Etymology. The specific epithet malabarbai (n. m. gen. sg.) comes from Malabarba. The specific name malabarbai is a patronym for Luiz Roberto Malabarba, in recognition of his many contributions to Neotropical ichthyology.

Distribution. Phalloceros malabarbai is only known from the type locality (Fig. 4). 


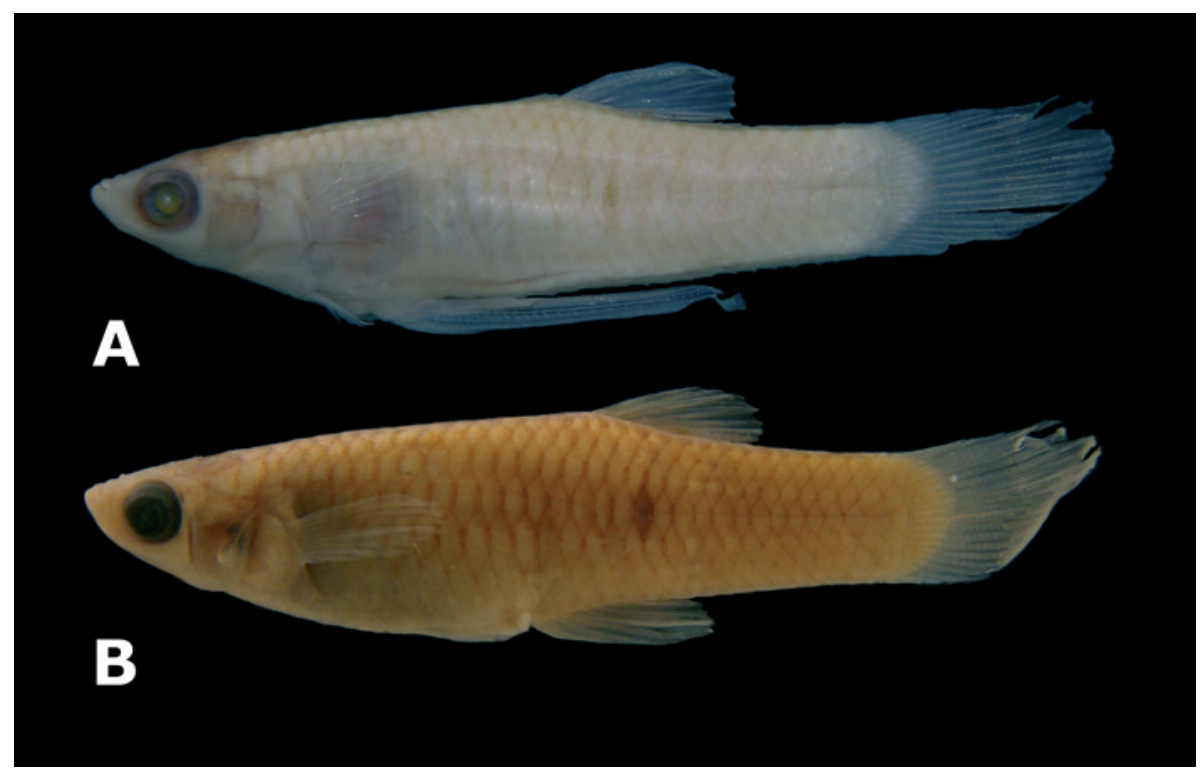

Fig. 36. Phalloceros megapolos. (A) Holotype, male, $23.4 \mathrm{~mm}$ SL, MCP 30405, rio Lindo, affluent to rio Cubatão, ca. $1 \mathrm{~km}$ from bifurcation on road from Pirabeiraba to Campo Alegre (road SC-301), Pirabeiraba, Santa Catarina, Brazil; (B) paratype, female, MCP 13735, $30.5 \mathrm{~mm}$ SL, collected with the holotype.

\section{Phalloceros megapolos, new species Figs. 36, 37}

Phalloceros sp. n. I Lucinda \& Reis (2005).

Holotype. MCP 30405, rio Lindo, affluent to rio Cubatão, ca. 1 km from bifurcation on road from Pirabeiraba to Campo Alegre (road

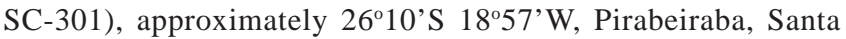
Catarina, Brazil, 4 May 1989, L.A. Bergman et al.

Paratypes. BRAZIL. Paraná. MHNCI 6525, 3, rio Cubatãozinho (affluent to rio São João at baía de Guaratuba. MHNCI 6780, 2, Guaratuba, tributary to rio Cubatãozinho at baía de Guaratuba. Santa Catarina. MCP 10507, 3 Joinville, arroio Lindo, rio Cubatão (Norte) drainage, nearby road SC-301 close to BR 101, Pirabeiraba, 19 Sep 1985, C.A.S. Lucena et al. MCP 13735, 11/4*, and USNM 320321, 12, collected with the holotype. MCP 13972, 1, Pirabeiraba, 9 May 1989, L.A. Bergman et al. MCP 31000, 564, Araquari, stream affluent to Canal do Linguado at Ilha de São Francisco do Sul, 26²2'8"S 4842'4"W, 20 Sep 2002, L.R. Malabarba et al. MCP 31137, 127, Joinville, rio Lindo on road SC $301 \mathrm{ca} .2 .1 \mathrm{~km}$ from road BR 101 (affluent to rio Cubatão Norte), 261'31"S 4855'44"W, 20 Oct 2002,V.A. Bertaco et al. MCP 31343, 2, same data as MCP 31137. MCP 31348, 7, Joinville, affluent stream to rio Cubatão Norte ca. $50 \mathrm{~m}$ from road BR 101, road SC 301, 26 12 ' 4 "S $48^{\circ} 54^{\prime} 59$ "W, 20 Oct 2002, V.A. Bertaco et al.

Diagnosis. Phalloceros megapolos can be easily and autapomorphically diagnosed by the appendix of the gonopodium greatly expanded in wing like projections (Fig. 37). Adult males of Phalloceros megapolos can be distinguished from their congeners by having pleural rib 7 longer than pleural rib 8 [57-1].

Description. Morphometric data in Tables 1 and 2. Range of SL: 21.7 to $39.7 \mathrm{~mm}$ (females), 17.4 to $23.4 \mathrm{~mm}$ (males). Dorsal- fin rays: $8 *$ [19]. Branched pectoral-fin rays: 6 [3], 7* [15]. Pelvic-fin rays: $5 *$ [6] (males), 5 [15] (females). Anal-fin rays of females: 10 [4], 11 [7]. Anal-fin rays of males: 9* [8]. Branched caudal-fin rays: 10 [1], 11* [8], 12 [5], 13 [2]. Predorsal scales: 13 [2], 14* [16]. Longitudinal series of scales: 29* [13], 30 [6]. Series of scales around caudal peduncle: $16^{*}$ [19]. Transverse series of scales: $7 *$ [19]. Serrae on R4p: 10 [1], 11 [2], 12 [3], 13* [2]. Epipleural ribs: 12 [4]. Pleural ribs: 14 [2], 15 [2]. Vertebrae: 32 [4]. Female urogenital papilla right curved, located laterally. Border of anal aperture in contact with first anal-fin ray or very close to it. Gonopodium appendix greatly expanded in wing like projections (Fig. 37).

Color in alcohol. Eye silvery brown with greenish brown pupil. Ground color cream, darker in upper half. Upper region of flanks and head densely covered with brown chromatophores, more concentrated along and nearby longitudinal series of scales, forming in some specimens inconspicuous band of brown chromatophores. Border of scales and subjacent skin replete with brown chromatophores, more concentrated at short distance

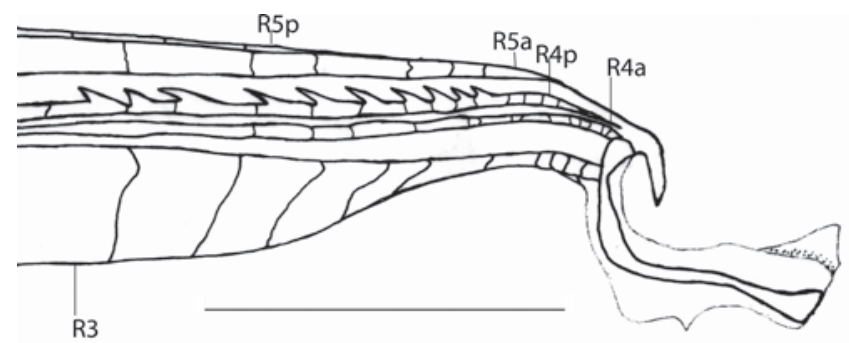

Fig. 37. Gonopodium tip of Phalloceros megapolos, MCP 13735. R3, R4a, R4p, R5a, R5p indicate gonopodial rays. Scale bar $1 \mathrm{~mm}$. 


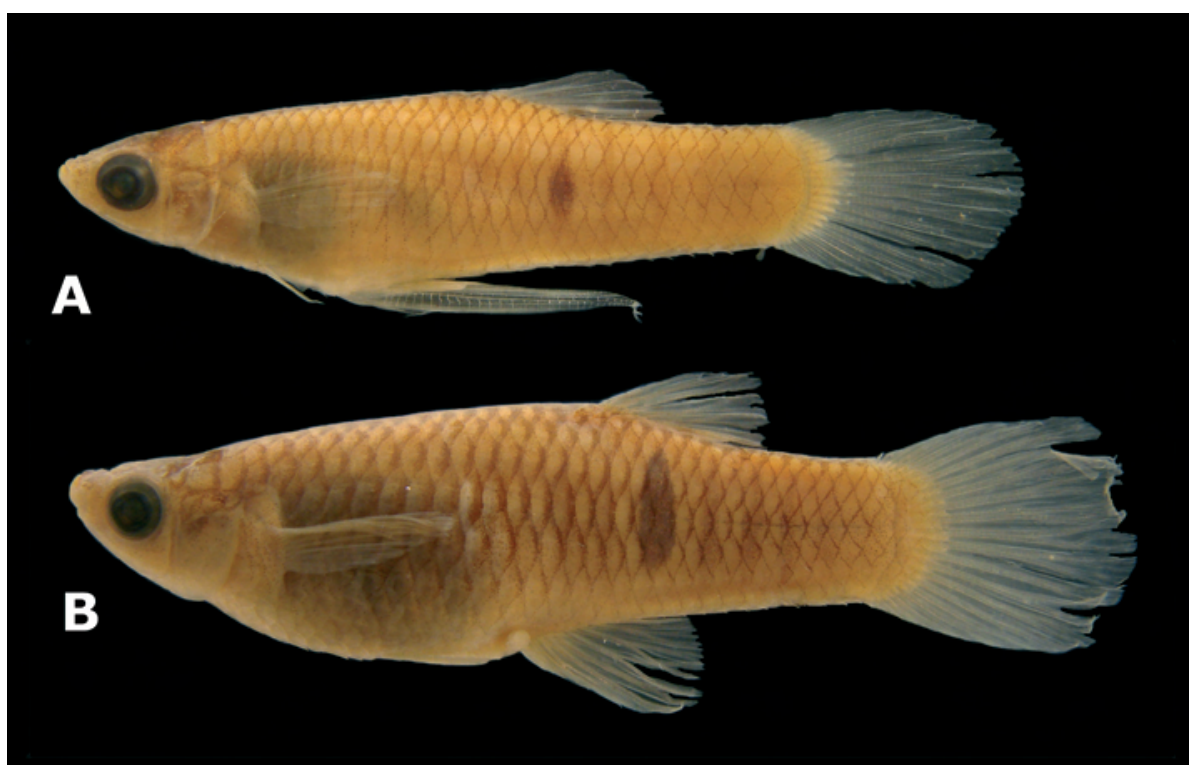

Fig. 38. Phalloceros lucenorum. (A) Holotype, male, 26.1 mm SL, MCP 30404, Juquiá, creek on road BR 116, near Juquiá (affluent to rio Juquiá), São Paulo, Brazil; (B) paratype, female, MCP 12197, 33.5 mm SL, collected with the holotype.

from scale border, conferring reticulate pattern to body sides, mainly on upper half. Brown chromatophores scattered through whole body, more concentrated on dorsal portion, mainly on head, snout, opercle, and ventral surface of mandible. Lateral spot very narrow, forming vertically elongated bar covering one scale in horizontal direction and two scales in vertical direction. Lateral spot located between $15^{\text {th }}$ and $16^{\text {th }}$, or over $16^{\text {th }}$, or $17^{\text {th }}$ scale of longitudinal series. Faint vertical bars along flanks sometimes present. Dorsal-fin membrane hyaline. Band of dark chromatophores on distal border of dorsal fin. Band of dark chromatophores near dorsal-fin base, more concentrated posteriorly. Pectoral-, pelvic-, anal, and caudal-fin rays unpigmented. Gonopodial rays unpigmented.

Etymology. From the Greek $\mu \varepsilon \gamma \alpha \varsigma,-\lambda \eta,-\alpha$ [= mégas, -le, -a], adj. m. nom. sg., meaning large, plus $\pi \mathrm{o} \lambda \mathrm{o}$ [ [= pólos], n. m. nom. sg., meaning rod, axle, pole, alluding to expanded terminal appendix of gonopodium. A noun in apposition.

Distribution. Drainages of the rio São João, rio Cubatão (Norte) and small adjacent drainages, which flows into the Baía de Guaratuba in Paraná State (Fig. 18).

\section{Phalloceros lucenorum +P. uai + P. buckupi + P. anisophallos $+P$. pellos $+P$. spiloura $+P$. reisi} Clade 74, Lucinda \& Reis (2005).

Diagnosis. Members of this clade share the following uniquely derived and unreversed feature: hooks on gonopodial paired appendix present only on left half [98-2**].

Additionally, this clade can be diagnosed by the following not uniquely derived and/or reversed features: (1) ten anal-fin rays in females [65-1]; (2) halves of gonopodial paired appendix different from each other; right half much wider than left one [95-1*]; and (3) halves of gonopodial paired appendix sickle like, lacking a medium corner [96-1].

\section{Phalloceros lucenorum, new species}

Figs. 38, 39

\section{Phalloceros sp. n. O Lucinda \& Reis (2005).}

Holotype. MCP 30404, Juquiá, creek on road BR 116, near Juquiá (affluent to rio Juquiá), approximately $24^{\circ} 19^{\prime}$ S $47^{\circ} 37^{\prime}$ W, São Paulo, Brazil, 27 Jul 1988, C.A.S. Lucena et al.

Paratypes. BRAZIL. São Paulo. MCP 12553, 3, Juquiá, canal 8 km N of Prefeitura de Juquiá, on road SP 79, 9 Feb 1988, P.A. Buckup et al. MCP 27373, 2, Sete Barras, rio Iporanga, road from Juquiá to Sete Barras (affluent of rio Juquiá), 2418'59"S 4751'10"W, 29 Jan 2001, C.A.S. Lucena et al. MCP 12197, 87/6*, collected with the holotype. MZUSP 43470, 30, Juquiá, ribeirão Poço Grande, in Fazenda Poço Grande, tributary to rio Juquiá, Jan 1950, F. Lane.

Diagnosis. Phalloceros lucenorum can be autapomorphically diagnosed by the rectangular tip of hook on left half of gonopodial appendix (Fig. 39) (vs. rounded tip). Moreover, $P$. lucenorum can be distinguished from its congeners but $P$. megapolos, $P$. spiloura, $P$. malabarbai, $P$. alessandrae, $P$. buckupi, P. uai, P. anisophallos, P. pellos, and P. reisi by (1) the female urogenital papilla curved to the right, located laterally (vs. slightly left turned and with a lateral ramus or straight located along midventral line) and (2) border of the anal aperture in contact with the first anal-fin ray or very close to it ( $v s$. separated from first anal-fin ray by the female urogenital papilla).

Phalloceros lucenorum can be distinguished from its congeners but P. spiloura, P. uai, P. anisophallos, P. pellos, and $P$. reisi by (1) the absence of the right hook and presence of 
the left one ( $v s$. absence or presence of left and right hooks); and (2) gonopodial appendix asymmetrical, its halves different from each other; right half wider than left one ( $v s$. gonopodial appendix symmetrical; its halves similar to each other).

Phalloceros lucenorum can be distinguished from $P$. spiloura by the absence of a caudal peduncle spot (vs. presence of caudal peduncle spot); from $P$. uai by the presence of a wide and square-shaped lateral spot in large specimens (vs. absence of such spot); from $P$. anisophallos by the lateral spot in adult females elliptical to roundish, but never forming a vertical bar (vs. lateral spot very narrow, forming a vertically elongated bar covering up to the length corresponding to two scales length in horizontal direction and 2-4 scales in vertical direction); from $P$. reisi by lateral spot always present and evident not covering the length corresponding to more than two scales length in horizontal or vertical directions (vs. lateral spot absent or small and discrete not covering the length corresponding to one or two scales length in horizontal or vertical directions).

Description. Morphometric data in Tables 3 and 4. Range of SL: 26.9 to $37.0 \mathrm{~mm}$ (females), 18.5 to $28.0 \mathrm{~mm}$ (males). Dorsalfin rays: 7 [3], 8* [38]. Branched pectoral-fin rays: $7 *$ [29]. Pelvic-fin rays: $5 *$ [17] (males), 5 [17] (females). Anal-fin rays of females: 10 [8], 11 [9]. Anal-fin rays of males: 9* [26]. Branched caudal-fin rays: 11 [6], 12* [23], 13 [5], 14 [2]. Predorsal scales: 13 [4], 14* [27], 15 [8],16 [1]. Longitudinal series of scales: 28* [26], 29 [16], 30 [1]. Series of scales around caudal peduncle: $16^{*}$ [43]. Transverse series of scales: $7 *$ [43]. Serrae on R4p: 9 [1],10* [12], 11 [3], 12 [8], 14 [1]. Epipleural ribs: 11 [2], 12 [1], 13 [2], 14 [1]. Pleural ribs: 13 [1], 14 [2], 15 [3]. Vertebrae: 31 [1], 32 [5]. Female urogenital papilla right curved, located laterally. Border of anal aperture in contact with first anal-fin ray or very close to it. Halves of gonopodial paired appendix sickle like. Medial corner absent. Hook on left half of gonopodial paired appendix. Right hook absent. Hook on left half of gonopodial appendix with rectangular tip (Fig. 39).

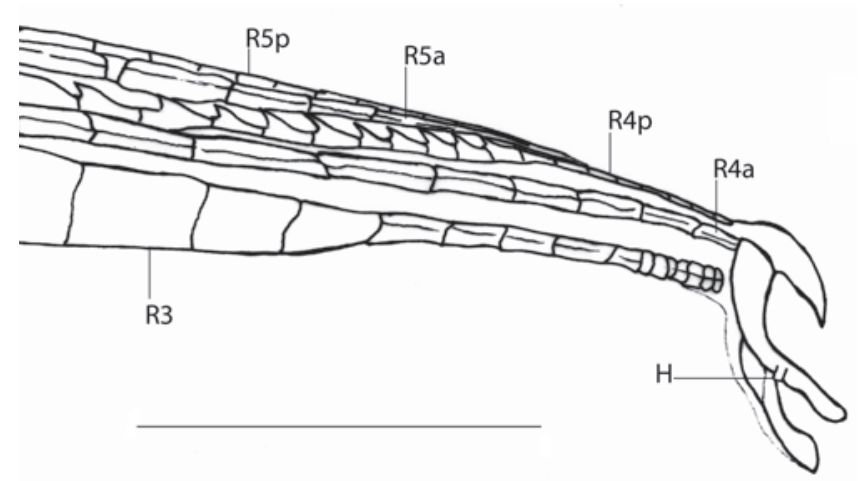

Fig. 39. Gonopodium tip of Phalloceros lucenorum, MCP 12197. R3, R4a, R4p, R5a, R5p indicate gonopodial rays. Scale bar $1 \mathrm{~mm}$.
Color in alcohol. Eye black with greenish brown pupil. Ground color pale brown, darker in upper half. Border of scales and subjacent skin replete with brown chromatophores, more concentrated at short distance from scale border, conferring reticulate pattern to body sides, mainly on upper half. Brown chromatophores scattered through whole body, more concentrated on dorsal portion, mainly on head, snout, opercle, and ventral surface of mandible. Lateral spot large covering approximately two or three scales on horizontal direction, and three to five scales on vertical. Dorsal-fin membrane hyaline. Dark band of chromatophores on distal border of dorsal fin. Dark band of chromatophores near dorsal-fin base. Pectoral, pelvic-, anal-, and caudal-fin rays unpigmented. Dark brown line along R3.

Etymology. The specific epithet lucenorum (n. m. gen. pl.) comes from Lucena. It is a patronym for Carlos A.S. Lucena and Zilda Margarete S. Lucena, in recognition of their many contributions to Neotropical ichthyology.

Distribution. Rio Juquiá, a tributary to the drainage of the rio Ribeira de Iguape in the State of São Paulo (Fig. 12).

\section{Phalloceros uai + P. buckupi \\ Clade 71, Lucinda \& Reis (2005)}

Diagnosis. Members of this clade share the following not uniquely derived and/or reversed features: (1) anterior cleft of anguloarticular small, not extending beyond posterior border of Meckel's cartilage [17-0]; (2) ventral process of anguloarticular long, extending anterior to where anguloarticular overlaps dentary [18-0]; and (3) first proximal radial of dorsal fin located between arches neural of $14^{\text {th }}$ and $15^{\text {th }}$ vertebrae in adult females [63-4].

\section{Phalloceros uai, new species}

Figs. 40, 41

Phalloceros sp. n. P Lucinda \& Reis (2005).

Holotype. MNRJ 23608, córrego do Jaque, tributary to the left margin of the rio das Velhas, 19³4'28"S 435'26"W, Lagoa Santa, Minas Gerais, Brazil, 24 Nov 2000, P.A. Buckup et al.

Paratypes. BRAZIL. Minas Gerais. MCP 30511, 6/2*, collected with the holotype. MNRJ 21604, 11, Jaboticatubas, creek tributary to the right margin of the rio das Velhas, 24 Nov 2000, P.A. Buckup et al. MNRJ 21617, 14, collected with the holotype.

Diagnosis. Phalloceros uai is autapomorphically diagnosed by a lateral spot wide and square-shaped in large specimens [134-3*] (Fig. 40). Moreover, P. uai can be distinguished from its congeners but P. megapolos, P. spiloura, P. malabarbai, $P$. alessandrae, $P$. buckupi, $P$. anisophallos, $P$. lucenorum, $P$. pellos, and $P$. reisi by (1) the female urogenital papilla curved 


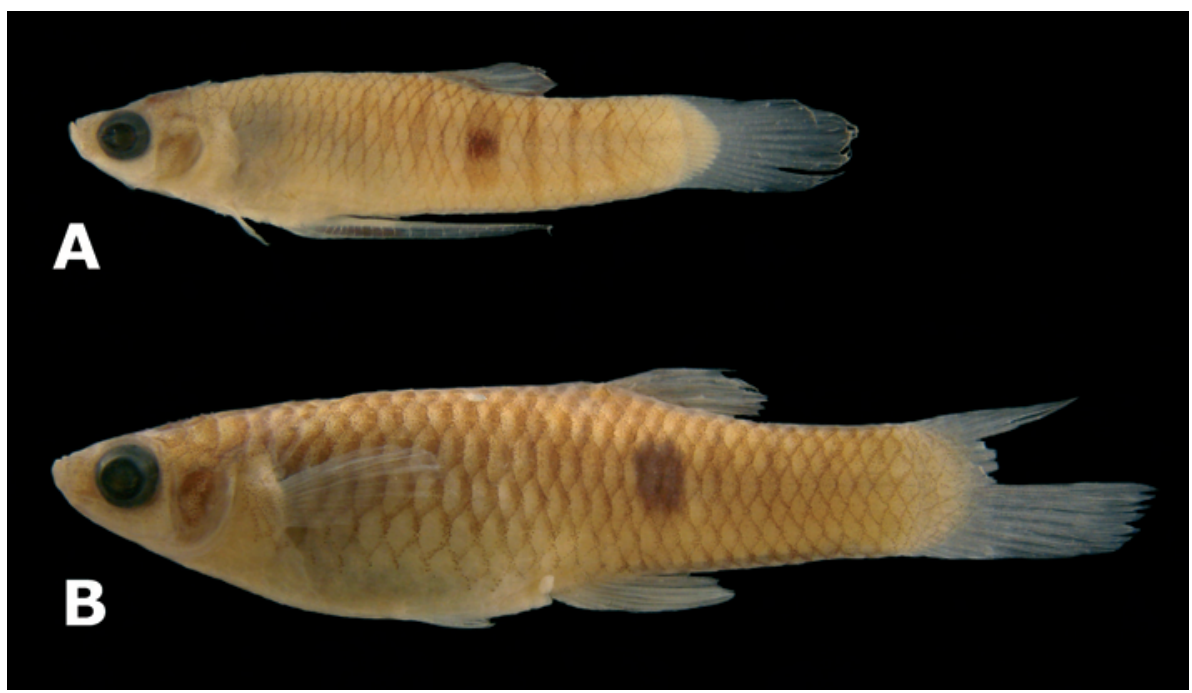

Fig. 40. Phalloceros uai. (A) Holotype, male, $16.6 \mathrm{~mm}$ SL, MNRJ 23608, córrego do Jaque, tributary to the left margin of the rio das Velhas, Lagoa Santa, Minas Gerais, Brazil; (B) paratype, female, MCP 30511, $31.8 \mathrm{~mm}$ SL, collected with the holotype.

to the right, located laterally (vs. slightly left turned and with a lateral ramus or straight located along midventral line); and (2) border of the anal aperture in contact with the first anal-fin ray or very close to it (vs. separated from first anal-fin ray by the female urogenital papilla).

Phalloceros uai can be distinguished from its congeners but $P$. spiloura, $P$. anisophallos, $P$. lucenorum, $P$. pellos, and $P$. reisi by (1) the absence of the right hook and presence of the left one (vs. absence or presence of left and right hooks); and (2) gonopodial appendix asymmetrical; its halves different from each other; right half wider than left one ( $v s$. gonopodial appendix symmetrical; its halves similar to each other).

Description. Morphometric data in Tables 7 and 8. Range of SL: 18.7 to $33.8 \mathrm{~mm}$ (females), 15.3 to $16.6 \mathrm{~mm}$ (males). Dorsalfin rays: $8 *$ [20]. Branched pectoral-fin rays: 5 [1], 6 [2], $7 *$ [9]. Pelvic-fin rays: $5 *$ [2] (males), 5 [14] (females). Anal-fin rays of females: 10 [15]. Anal-fin rays of males: $9 *$ [5]. Branched caudal-fin rays: 9 [1], 10* [6], 11 [5], 12 [6]. Predorsal scales: 13 [6], 14* [11], 15 [1]. Longitudinal series of scales: 27 [2], 28 [7], 29* [9]. Series of scales around caudal peduncle: $16^{*}[19]$. Transverse series of scales: $7 *$ [19]. Serrae on R4p: $7 *$ [1], 8 [2], 9 [1]. Epipleural ribs: 12 [2]. Pleural ribs: 14 [1], 15 [1]. Vertebrae: 32 [1], 33 [1]. Female urogenital papilla right curved, located laterally. Border of anal aperture in contact with first anal-fin ray or very close to it. Halves of gonopodial paired appendix sickle like. Medial corner absent. Hook on left half of gonopodial paired appendix. Right hook absent (Fig. 41).

Color in alcohol. Eye iridescent grey with greenish brown pupil. Ground color pale brown, darker in upper half. Border of scales and subjacent skin replete with brown chromatophores, more concentrated at short distance from scale border, conferring reticulate pattern to body sides. Brown chro- matophores scattered through whole body, more concentrated on dorsal portion, mainly on head, snout, opercle, and ventral surface of mandible. Lateral spot wide and square-shaped in large specimens. Lateral dark brown spot located over $14^{\text {th }}$ and $15^{\text {th }}$, or $15^{\text {th }}$ and $16^{\text {th }}$ or $16^{\text {th }}$ and $17^{\text {th }}$ scale of longitudinal series. Lateral spot covering approximately two scales on horizontal direction, and three scales on vertical. Dorsal-fin membrane bearing dark band of chromatophores on distal border of dorsal fin. Dark band of chromatophores near dorsal-fin base. Pectoral, pelvic, and caudal fins hyaline. Dark brown line along R3.

Etymology. Uai is an interjection typical of the natives of the State of Minas Gerais. It usually serves to express surprise, but also everything else. The epithet uai is a homage to Minas Gerais, my birthplace. A noun in apposition.

Distribution. Rio das Velhas, rio São Francisco basin (Fig. 7).

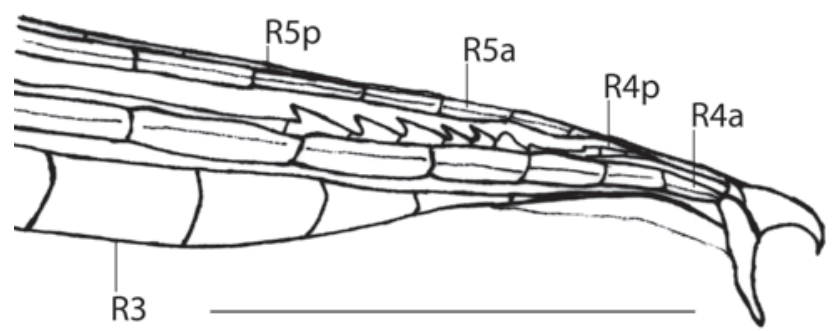

Fig. 41. Gonopodium tip of Phalloceros uai, MCP 30511. R3, R4a, R4p, R5a, R5p indicate gonopodial rays. Scale bar $1 \mathrm{~mm}$. 


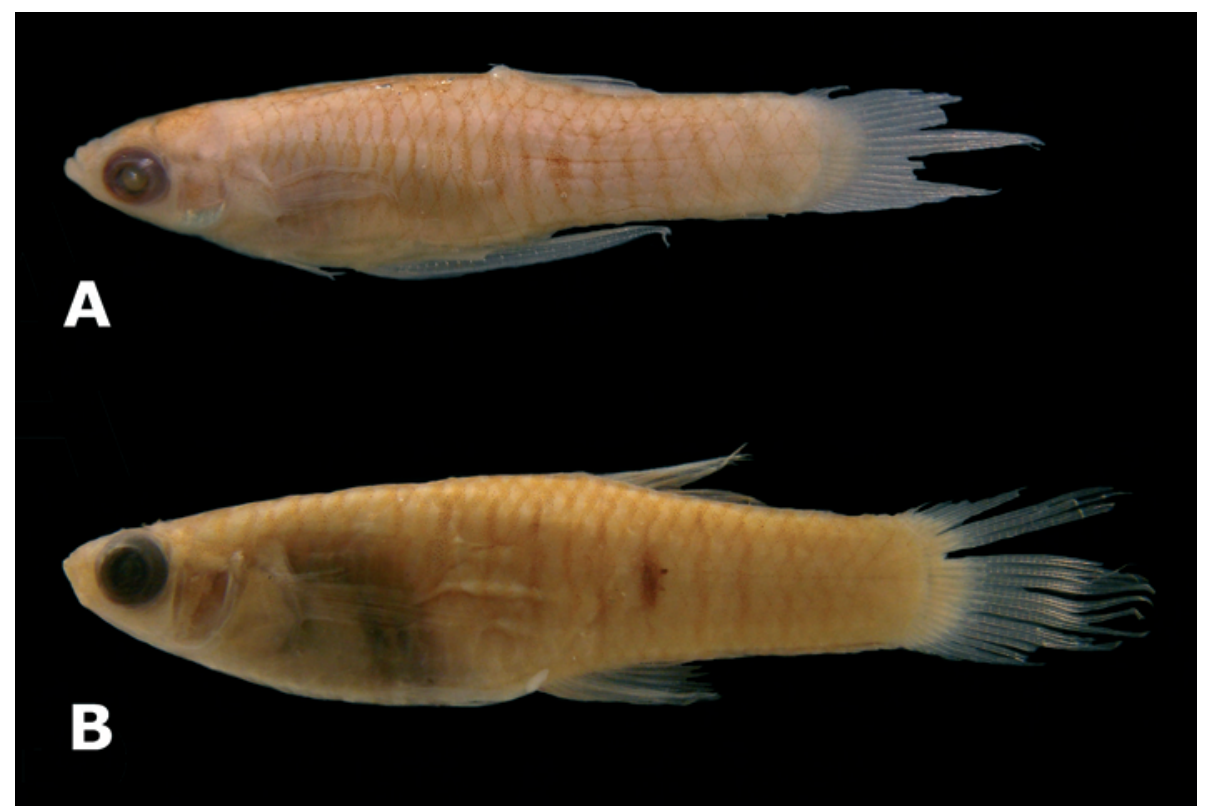

Fig. 42. Phalloceros buckupi. (A) Holotype, male, 19.3 mm SL, MCP 30472, Paranaguá, rio Jacareí at km 18 on road BR 277, border Paranaguá - Morretes, Brazil; (B) paratype, female, MCP 12549, 25.6 mm SL, collected with the holotype.

\section{Phalloceros buckupi, new species \\ Figs. 42, 43}

Phalloceros sp. n. M Lucinda \& Reis (2005).

Holotype. MCP 30472, Paranaguá, rio Jacareí at km 18 on road BR-277, border Paranaguá - Morretes, approximately 25³5’S 4843’W, Paraná, Brazil, 7 Jul 1988, P.A. Buckup et al.

Paratypes. BRAZIL. Paraná. MCP 12549, 4/1*; MCP 28440, 1, and UMMZ 215249, 4, collected with the holotype. MCP 12584, 7, Paranaguá, artificial ditches in Guaraguaçu, road PR 407, 7 km SE from Rio da Vila (S side of road), 7 Feb 1988, P.A. Buckup et al. Santa Catarina. MCP 31190, 102, Araquari, stream affluent to rio Parati ca. 1 km from road BR 280, 26²2'58"S 4843’33", 19 Sep 2002, L.R. Malabarba et al.

Diagnosis. Phalloceros buckupi can be distinguished from its congeners but $P$. megapolos, $P$. spiloura, P. malabarbai, $P$. alessandrae, $P$. anisophallos, $P$. uai, $P$. lucenorum, $P$. pellos, and $P$. reisi by (1) the female urogenital papilla curved to the right, located laterally (vs. slightly left turned and with a lateral ramus or straight located along midventral line); and (2) border of the anal aperture in contact with the first anal-fin ray or very close to it (vs. separated from first anal-fin ray by the female urogenital papilla).

Phalloceros buckupi can be distinguished from $P$. spiloura by the absence of a caudal peduncle spot (vs. presence of caudal peduncle spot); from $P$. megapolos by the gonopodium appendix normally developed (vs. greatly expanded in wing like projections); from $P$. uai by the absence of a wide and square-shaped lateral spot in large specimens (vs. presence of such spot).

Phalloceros buckupi can be distinguished from $P$. alessandrae and P. malabarbai by (1) halves of gonopodial paired appendix sickle like (vs. not sickle like); (2) medial corner absent (vs. present); (3) hook on left half of gonopodial paired appendix and right hook absent (vs. hook on both halves of gonopodial paired appendix); and (4) left hook small, directed downward or up- and forward, and located closer to the base of gonopodial appendix (vs. hooks large downward directed and located in the corner of gonopodial appendix) (Fig. 43).

Phalloceros buckupi can be distinguished from $P$. anisophallos, $P$. lucenorum, $P$. pellos, and $P$. reisi by the halves of the gonopodium slender and similar to each other (vs. halves of the gonopodium wide and different from each other; right half wider than left one).

Description. Morphometric data in Tables 3 and 4. Range of SL: 21.7 to $32.9 \mathrm{~mm}$ (females), 17.8 to $19.9 \mathrm{~mm}$ (males). Dorsalfin rays: 7 [1], $8 *$ [8]. Branched pectoral-fin rays: $7 *[3]$. Pelvic-fin rays: $5 *$ [5] (males), 5 [5] (females). Anal-fin rays of

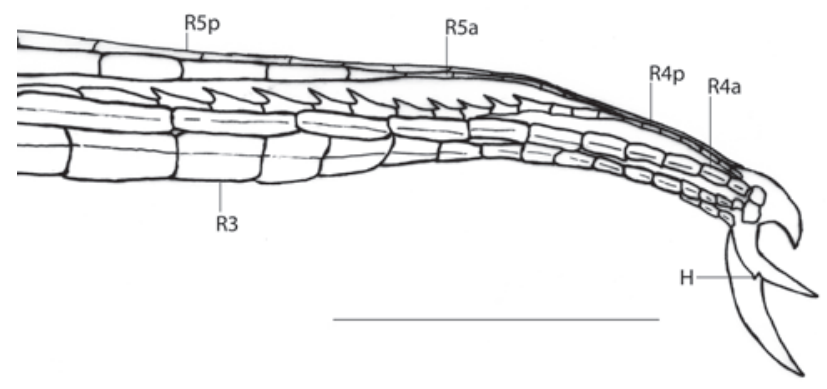

Fig. 43. Gonopodium tip of Phalloceros buckupi, MCP 31190. R3, R4a, R4p, R5a, R5p indicate gonopodial rays. Scale bar 1 $\mathrm{mm}$. 


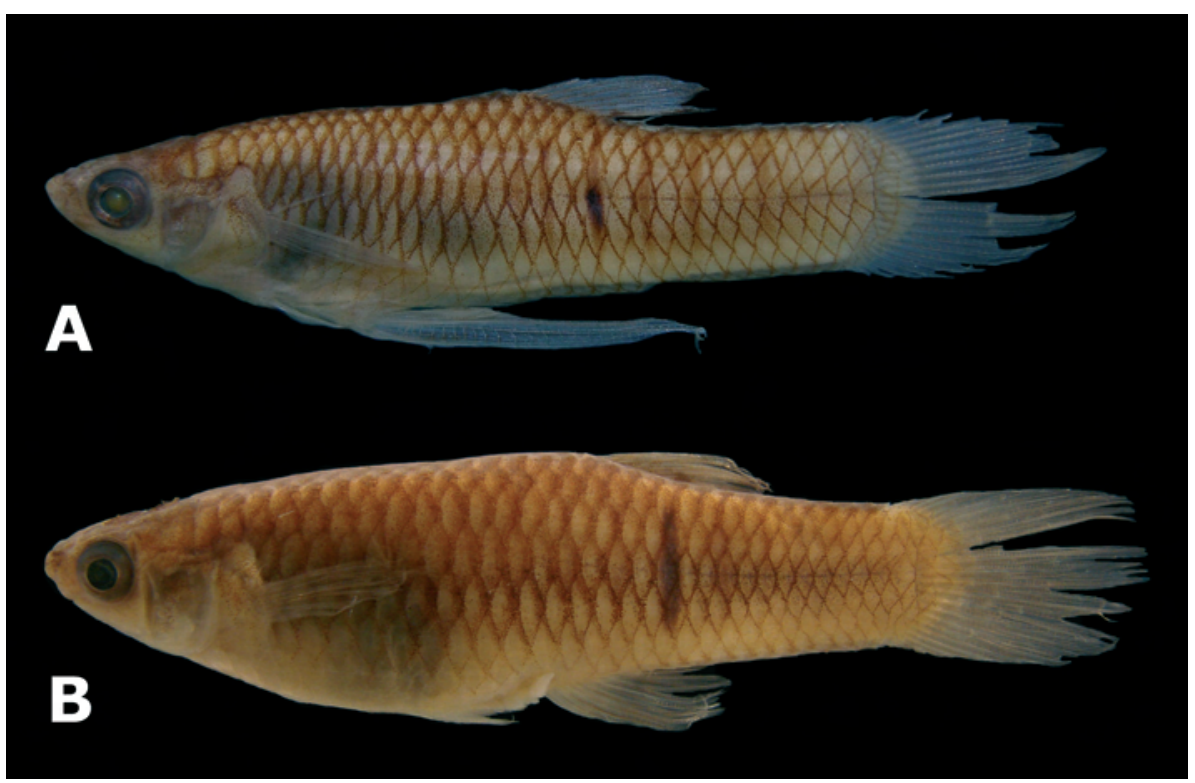

Fig. 44. Phalloceros anisophallos. (A) Holotype, male, 28.2 mm SL, MCP 30403, rio São Roque nearby road BR 101 N of Parati, Parati, Rio de Janeiro, Brazil; (B) paratype, female, MCP 12603, $41.3 \mathrm{~mm}$ SL, collected with the holotype.

females: 10 [5]. Anal-fin rays of males: $9 *$ [6]. Branched caudal-fin rays: 11 [3], $1 * 2$ [5]. Predorsal scales: 13 [1], 14* [8]. Longitudinal series of scales: 28 [1], 29 [5], 30* [3]. Series of scales around caudal peduncle: 16* [9]. Transverse series of scales: $7 *$ [9]. Serrae on R4p: 10* [3], 11 [2]. Epipleural ribs: 12 [1]. Pleural ribs: 14 [1]. Vertebrae: 32 [1]. Female urogenital papilla right curved, located laterally. Border of anal aperture in contact with first anal-fin ray or very close to it. Halves of gonopodial paired appendix sickle like. Medial corner absent. Hook on left half of gonopodial paired appendix. Right hook absent. Halves of gonopodial paired appendix slender and similar to each other (Fig. 43).

Color in alcohol. Eye silvery grey with greenish brown pupil. Ground color pale brown, darker in upper half. Border of scales and subjacent skin replete with brown chromatophores, more concentrated at short distance from scale border, conferring reticulate pattern to body sides, mainly on upper half. Brown chromatophores scattered through whole body, more concentrated on dorsal portion, mainly on head, snout, opercle, and ventral surface of mandible. Lateral dark brown spot located approximately over $16^{\text {th }}$ scale of longitudinal series. Lateral spot covering approximately one scale on horizontal direction, and three scales on vertical. Light brown vertical bars along flanks (absent in one specimen studied). Dorsalfin membrane bearing dark band of chromatophores on distal border of dorsal fin. Dark band of chromatophores near dorsal-fin base. Pectoral-, pelvic-, anal-, and caudal-fin rays unpigmented. Dark brown line along R3.

Remarks. Specimens from Caraguaçu (MCP 12584) are darker than remaining specimens, with the dark bands on dorsal fin more evident and the vertical bars inconspicuous or absent.
Etymology. The specific epithet buckupi (n. m. gen. sg.) comes from Buckup. It is a patronym for Paulo A. Buckup (collector of most specimens of this species) in recognition of his many contributions to Neotropical ichthyology.

Distribution. Phalloceros buckupi is known to occur in the rio Jacareí drainage and neighbouring, which flows into the Baía de Paranaguá in the coast of Paraná State of Brazil (Fig. 12).

\section{Phalloceros anisophallos + P. pellos \\ Clade 72, Lucinda \& Reis (2005)}

Diagnosis. Members of this clade share the following not uniquely derived and/or reversed feature: distal portion third and fourth gonactinosts completely fused [74-1].

\section{Phalloceros anisophallos, new species Figs. 44, 45}

\section{Phalloceros sp. n. H Lucinda \& Reis (2005).}

Holotype. MCP 30403, rio São Roque nearby road BR 101, N of Parati, Parati, Rio de Janeiro, Brazil, 2325'0"S 4440’5"W, 10 Feb 1988, P.A. Buckup et al.

Paratypes. Brazil. Rio de Janeiro. MCP 12603, 87/4*, collected with the holotype. MCP 31132, 18, Parati, rio Taquari at Taquari

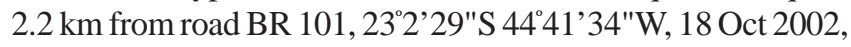
V.A. Bertaco et al. MCP 31134, 69, Parati, stream affluent to rio Taquari ca. $2.3 \mathrm{~km}$ from BR 101, near Tarituba, 23'2’29"S 4441'38"W, 18 Oct 2002, V.A. Bertaco et al. MCP 31136, 53, Parati, rio São Roque on road BR 101 near Tarituba, 23\%4'35"S 444ㄴ'51"W, 19 Oct 2002, V.A. Bertaco et al. MNRJ 12502, 6, 
Parati, upper portion of rio Barra Grande, 11 May 1993, F.J. Lobon-Cervia. UMMZ 215277, 121, Parati, rio São Roque at bridge of BR-101, N of Parati, 232'30"S 4440"W, 10 Feb 1988, P.A. Buckup et al. USNM 307821, 16, rio Itinguçu, border of Itaguaí and Mangaratiba, km 25, Rodovia Rio-Santos, 24 Apr 1989, R.S. Rosa \& A.J. Sales. USNM 307827, 6, rio Barra Grande, 20 km N of Parati, km 168 Rodovia Rio-Santos, 24 Apr 1989, R.S. Rosa \& A.J. Sales. UNT 6772, 6, Angra dos Reis, córrego Andorinha, Ilha Grande, 235’23"S 446’34"W, 20 Apr 2002, R. Mazzoni et al.

Diagnosis. Phalloceros anisophallos can be autapomorphically diagnosed by (1) hook on left half of gonopodial appendix near its tip, located approximately from distal quarter to the distal third of length of gonopodial appendix (Fig. 45); and (2) spot on median region of flanks elongate, forming a vertical bar reaching dorsal and ventral profiles (Fig. 44) [134-4*].

Moreover, $P$. anisophallos can be distinguished from its congeners but $P$. megapolos, $P$. spiloura, $P$. malabarbai, $P$. alessandrae, P. buckupi, P. uai, P. lucenorum, P. pellos, and $P$. reisi by (1) the female urogenital papilla curved to the right, located laterally (vs. slightly left turned and with a lateral ramus or straight located along midventral line); and (2) border of the anal aperture in contact with the first anal-fin ray or very close to it (vs. separated from first anal-fin ray by the female urogenital papilla).

Phalloceros anisophallos can be distinguished from its congeners but $P$. spiloura, P. uai, P. lucenorum, P. pellos, and $P$. reisi by (1) the absence of the right hook and presence of the left one (vs. absence or presence of left and right hooks), and (2) gonopodial appendix asymmetrical; its halves different from each other; right half wider than left one (vs. gonopodial appendix symmetrical; its halves similar to each other).

Phalloceros anisophallos can be distinguished from $P$. spiloura by the absence of a caudal peduncle spot (vs. presence of caudal peduncle spot); from $P$. uai by the presence of a wide and square-shaped lateral spot in large specimens (vs.

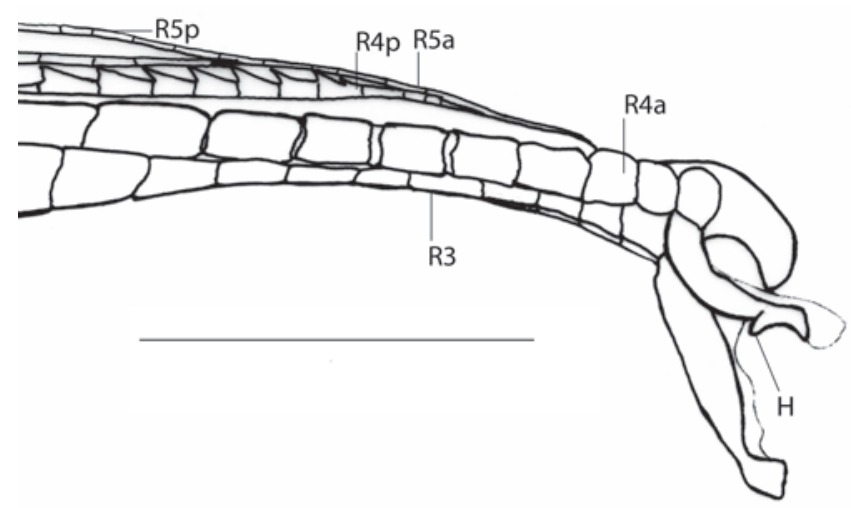

Fig. 45. Gonopodium tip of Phalloceros anisophallos, MCP 12603. R3, R4a, R4p, R5a, R5p indicate gonopodial rays. Scale bar $1 \mathrm{~mm}$. absence of such spot); from $P$. lucenorum by rectangular tip of hook on left half of gonopodial appendix ( $v s$. rounded tip); from $P$. lucenorum, $P$. pellos, and $P$. reisi by the lateral spot in adult females very narrow, forming a vertically elongated bar covering up to the length corresponding to two scales length in horizontal direction and 2-4 scales in vertical direction (vs. lateral spot in adult females absent, small, or elliptical to roundish, but never forming a vertical bar).

Description. Morphometric data in Tables 5 and 6. Range of SL: 21.9 to $45.1 \mathrm{~mm}$ (females), 16.2 to $28.2 \mathrm{~mm}$ (males). Dorsalfin rays: 7 [4], 8* [34]. Branched pectoral-fin rays: 5 [3], 6 [3], $7 *$ [25]. Pelvic-fin rays: $5 *$ [8] (males), 5 [28] (females). Analfin rays of females: 10 [26], 11 [1]. Anal-fin rays of males: 9* [11]. Branched caudal-fin rays: 10 [1], 11 [4], 12* [25], 13 [3], 14 [1]. Predorsal scales: 13 [4], 14* [33], 15 [1]. Longitudinal series of scales: 28 [7], 29* [32]. Series of scales around caudal peduncle: 16* [38]. Transverse series of scales: 6 [1], 7* [38]. Serrae on R4p: 9 [3], 10 [3], 11 [3], 12* [2]. Epipleural ribs: 11 [1], 12 [2], 13 [1]. Pleural ribs: 14 [3], 15 [1]. Vertebrae: .32 [4]. Female urogenital papilla right curved, located laterally. Border of anal aperture in contact with first anal-fin ray or very close to it. Halves of gonopodial paired appendix sickle like. Medial corner absent. Hook on left half of gonopodial paired appendix. Right hook absent. Hook on left half of gonopodial appendix near its tip, located approximately from distal quarter to distal third of gonopodial appendix (Fig. 45).

Color in alcohol. Eye silvery brown with greenish brown pupil. Ground color cream, darker in upper half. Upper region of flanks and head densely covered with brown chromatophores. Border of scales and subjacent skin replete with brown chromatophores, more concentrated at short distance from scale border, conferring reticulate pattern to body sides, mainly on upper half. Brown chromatophores scattered through whole body, more concentrated on dorsal portion, mainly on head, snout, opercle, and ventral surface of mandible. Lateral spot very narrow, forming vertically elongated bar covering up to two scales in horizontal direction and two to four scales in vertical direction. Lateral spot of larger females inconspicuous. Faint vertical bars along flanks sometimes present. Dorsal-fin membrane hyaline. Faint band of chromatophores on distal border of dorsal fin and another one near dorsal-fin base. Pectoral-, pelvic-, anal, and caudal-fin rays unpigmented. Dark brown line along R3.

Etymology. From the Greek, $\alpha v i \sigma o \varsigma,-o v$ [= anisos, -on], adj. $\mathrm{m}$. nom. sg., meaning unequal, uneven, plus $\phi \alpha \lambda \lambda \mathrm{s}[=$ phallós], n. m. nom. sg., meaning penis, phallus, alluding to the asymmetrical terminal appendix of gonopodium. A noun in apposition.

Distribution. Phalloceros anisophallos is known from the drainages of rio Parati, rio Barra Grande, rio São Roque, rio Taquari and rio Itinguçu (small coastal drainages of the State of Rio de Janeiro) (Fig. 7). 


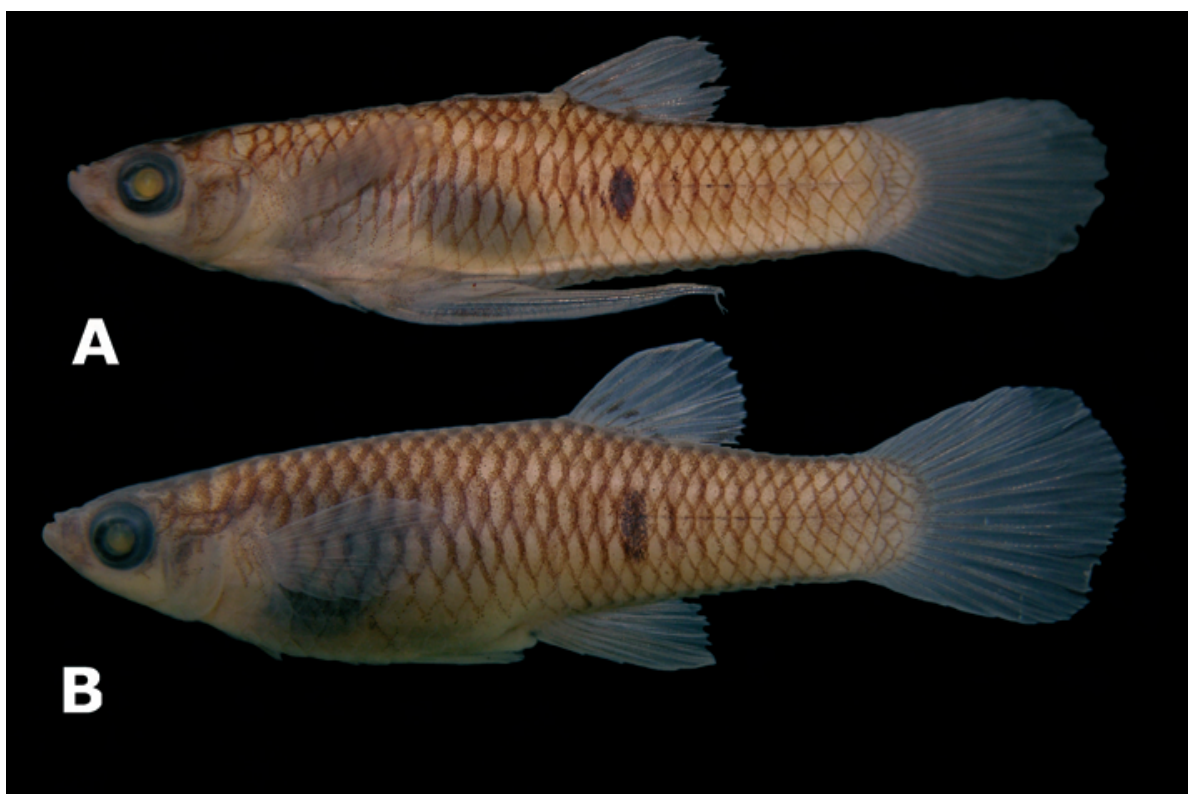

Fig. 46. Phalloceros pellos. (A) Holotype, male, 26.4 mm SL, MCP 31142, Antonina, lateral pond on road near rio Nunes, Paraná, Brazil; (B) paratype, female, MCP 31141, 29.9 mm SL, collected with the holotype.

\section{Phalloceros pellos, new species}

Figs. 46, 47

Phalloceros sp. n. Q Lucinda \& Reis (2005).

Holotype. MCP 31142, Antonina, lateral pond on road near rio Nunes, Paraná, Brazil, 2520’29"S 4846’29"W, 23 Sep 2002, L.R. Malabarba et al.

Paratypes. Brazil. Paraná. MCP 31138, 2, Guaraqueçaba, creek along road PR 404, affluent to rio Tagaçaba, 2512'33"S 48²6'1"W, 22 Sep 2002, L.R. Malabarba et al. MCP 31141, 121, collected with the holotype. MHNCI 6151, 8/2*, creek at Praia do Forte, Ilha do Mel, Paranaguá, 18 Jun 1991, E. Grando Jr. \& W.B. Wosiacki. MHNCI 6262, 4/2*, Pontal do Paraná, Balneário de Shangri-lá, 8 Aug 1990, E. Grando Jr. MHNCI 6237, 3, Pontal do Paraná, estrada do Lixão, 13 Nov 1991, E. Grando Jr. et al. MHNCI 9068, 1, Guaraqueçaba, creek at Vila do Superagui, Ilha do Superagui, 28 Aug 1991, E. Grando Jr. \& W.B. Wosiacki.

Diagnosis. Phalloceros pellos can be distinguished from its congeners but $P$. megapolos, $P$. spiloura, $P$. malabarbai, $P$. alessandrae, $P$. buckupi, $P$. uai, $P$. lucenorum, $P$. anisophallos, and $P$. reisi by (1) the female urogenital papilla curved to the right, located laterally (vs. slightly left turned and with a lateral ramus or straight located along midventral line); and (2) border of the anal aperture in contact with the first anal-fin ray or very close to it (vs. separated from first anal-fin ray by the female urogenital papilla).

Phalloceros pellos can be distinguished from its congeners but $P$. spiloura, $P$. uai, $P$. lucenorum, $P$. anisophallos, and $P$. reisi by (1) the absence of the right hook and presence of the left one ( $v s$. absence or presence of left and right hooks); and (2) gonopodial appendix asymmetrical; its halves different from each other; right half wider than left one (vs. gonopodial appendix symmetrical; its halves similar to each other) (Fig. 47).

Phalloceros pellos can be distinguished from $P$. spiloura by the absence of a caudal peduncle spot ( $v s$. presence of caudal peduncle spot); from $P$. uai by the presence of a wide and square-shaped lateral spot in large specimens (vs. absence of such spot); from $P$. anisophallos by the lateral spot in adult females elliptical to roundish, but never forming a vertical bar (vs. lateral spot very narrow, forming a vertically elongated bar covering up to the length corresponding to two scales length in horizontal direction and 2-4 scales in vertical direction); from $P$. lucenorum by a rounded tip of the hook on left half of gonopodial appendix (vs. rectangular tip).

Phalloceros pellos can be distinguished from $P$. reisi by (1) hook on left appendix very small (vs. larger), (2) lateral spot always present and evident not covering more than the length corresponding to two scales length in horizontal or vertical directions (vs. absent or small and discrete not covering one or two scales in horizontal or vertical directions).

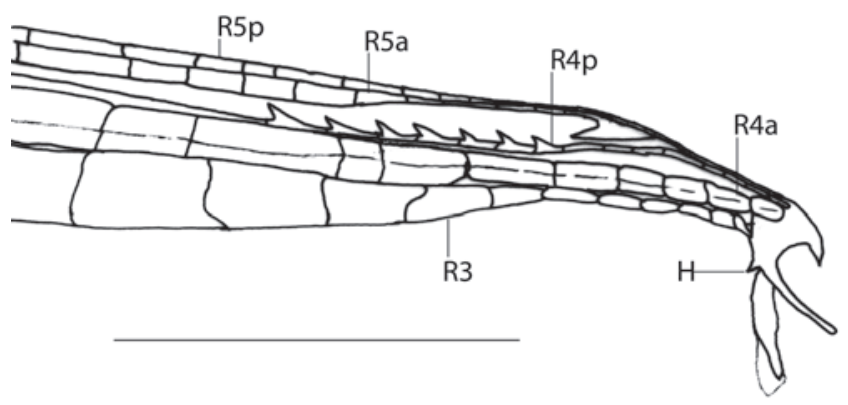

Fig. 47. Gonopodium tip of Phalloceros pellos, MHNCI 9068. R3, R4a, R4p, R5a, R5p indicate gonopodial rays. Scale bar 1 $\mathrm{mm}$. 


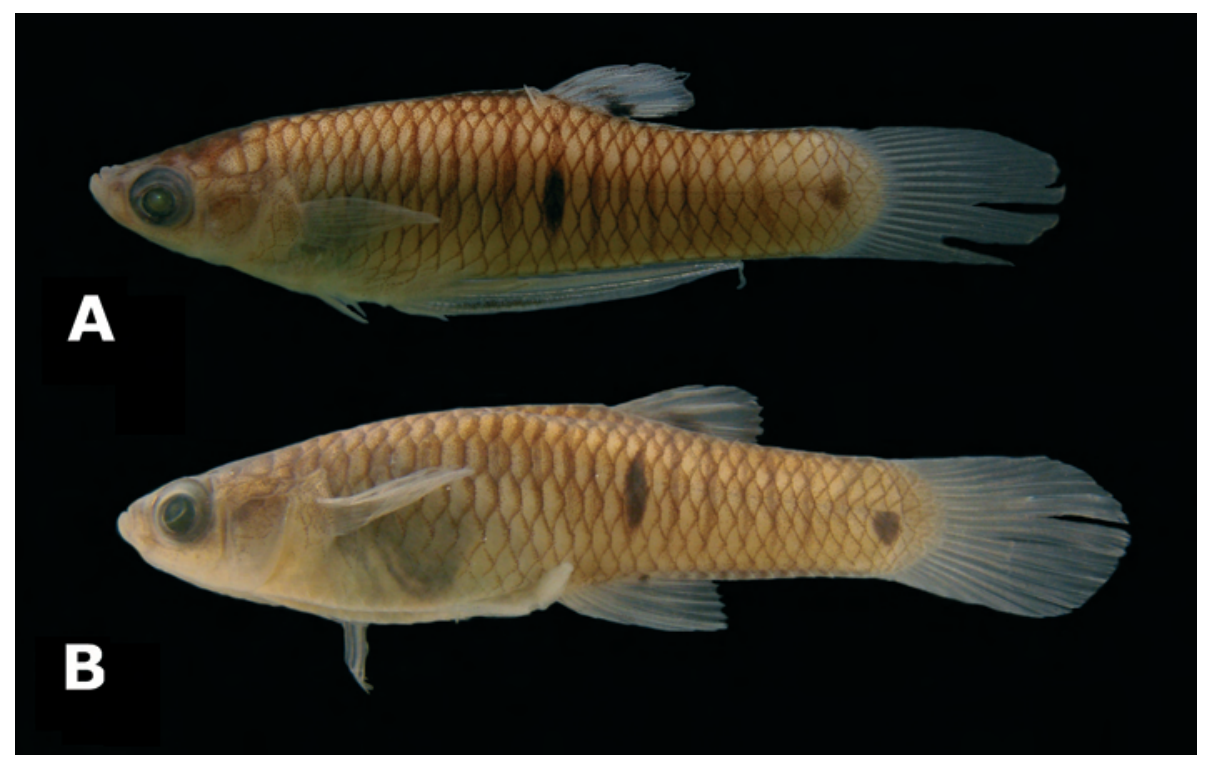

Fig. 48. Phalloceros spiloura. (A) Holotype, male, 22.0 mm SL, MCP 30401, creek ca. $200 \mathrm{~m}$ from arroio do Padre, Itati, Rio Grande do Sul, Brazil; (B) paratype, female, MCP 29270, 25.0 mm SL, collected with the holotype.

Description. Morphometric data in Tables 11 and 12. Range of SL: 23.3 to $33.2 \mathrm{~mm}$ (females), 21.5 to $24.1 \mathrm{~mm}$ (males). Dorsal-fin rays: $8^{*}$ [15]. Branched pectoral-fin rays: 5 [1], 6 [6], 7* [7]. Pelvic-fin rays: $5^{*}$ [7] (males), 5 [9] (females). Anal-fin rays of females: 10 [9]. Anal-fin rays of males: $8 *$ [1], 9 [6]. Branched caudal-fin rays: 11 [1], 12* [11]. Predorsal scales: 14* [13]. Longitudinal series of scales: 28 [7], 29 [7], 30* [1]. Series of scales around caudal peduncle: 16* [15]. Transverse series of scales: $7 *$ [15]. Serrae on R4p: 10* [1], 11 [6]. Epipleural ribs: 12 [2], 13 [1]. Pleural ribs: 13 [1], 14 [2], 15 [1]. Vertebrae: 31 [2], 32 [2]. Female urogenital papilla right curved, located laterally. Border of anal aperture in contact with first anal-fin ray or very close to it. Halves of gonopodial paired appendix sickle like. Medial corner absent. Hook on left half of gonopodial paired appendix. Right hook absent. Hook on left appendix very small (Fig. 47)

Color in alcohol. Eye black with greenish brown pupil. Background coloration dark brown, darker in upper half. Overall appearance dark. Border of scales and subjacent skin replete with brown chromatophores, more concentrated at short distance from scale border, conferring reticulate pattern to whole flanks. Brown chromatophores scattered through whole body, more concentrated on dorsal portion, mainly on head, snout, opercle, and ventral surface of mandible. Margin of scales on prepelvic region clearly defined bordered by dark chromatophores. Lateral dark brown spot located over $15^{\text {th }}$ and $16^{\text {th }}$ or $16^{\text {th }}$ and $17^{\text {th }}$ scale of longitudinal series. Lateral spot covering approximately two scales on horizontal direction, and two to four scales on vertical, sometimes reaching dorsal and ventral profiles. Inconspicuous vertical bars present in some individuals. Dorsal-fin membrane dusky, bearing dark band of chromatophores on distal border and dark band of chromatophores near dorsal-fin base. Pectoral-, pelvic- and caudal-fin rays dusky replete of brown chromatophores distributed along fin rays. First three anal-fin rays of females sometimes spotted with black. Dark brown line along R3.

Etymology. From the Greek $\pi \varepsilon \lambda \lambda \mathrm{o},,-\eta,-o v[=$ pellos, adj. $\mathrm{m}$. nom. sg.] meaning dark-colored, dusky, alluding to the background color.

Distribution. Small coastal drainages flowing into Baía de Paranaguá in Paraná State of Brazil (Fig. 4).

\section{Phalloceros spiloura + P. reisi}

Clade 73, Lucinda \& Reis (2005).

Diagnosis. Members of this clade share the following not uniquely derived and/or reversed feature: distal elements of R6 branches partially fused [127-1].

\section{Phalloceros spiloura, new species Figs. 48, 49}

Phalloceros sp. n. J Lucinda \& Reis (2005).

Holotype. MCP 30401, creek ca. 200 m from arroio do Padre, Itati, Rio Grande do Sul, Brazil, 29²9’04"S 5006’58"W, 26 Mar 2002, V. A. Bertaco \& J. F. P. Silva.

Paratypes. BRAZIL. Rio Grande do Sul. MCP 20293, 18, Torres, creek on dunes, 8 Nov 1997, R. E. Reis et al. MCP 28776, 2, Três Cachoeiras, rio das Pacas near Morro Azul, 15 Jan 1991, N. A. Menezes et al. MCP 29270, 256/6*, collected with the holotype. Santa Catarina. MCP 28731, 8, Garopaba, creek affluent to rio Araçatuba at Ressacada, 28 $8^{\circ} 04^{\prime} 18^{\prime \prime S} 48^{\circ} 42^{\prime} 00^{\prime \prime} \mathrm{W}, 26$ Oct 2001, L. R. Malabarba. MCP 29082, 27, same data as MCP 28731, $22 \mathrm{Feb}$ 2002. 
Non-types. BRAZIL. Rio Grande do Sul. MZUSP 4481, 10 of 11, Torres, praia de Torres. Santa Catarina. MCP 10502, 18, Gravatal, lateral channel along rio Capivari, on road from Tubarão to Gravatal. MCP 10659, 7, Tubarão, 1984. MCP 22336, 16, Urubici, rio Urubici near bridge S of Urubici (upper rio Uruguai). MCP 23715, 2, Jacinto Machado, arroio affluent of rio Sertão, ca. $13 \mathrm{~km} \mathrm{SW}$ from Jacinto Machado towards Praia Grande. MCP 27011, 17, Gaspar, açude at Sítio Althoff at Belchior Baixo, rio Itajaí-Açu basin. MCP 27446, 2, rio Negrinho, rio Preto drainage, affluent to rio Iguaçu. MCP 28442, 3, Joinville, arroio Lindo, rio Cubatão (North) drainage, nearby road SC 301 close to BR 101, Pirabeiraba. MCP 28491, 1, Itapocu, creek affluent to rio Itapocu, on road from BR 101 to Barra do Itapocu. MZUSP 2789, 11, Blumenau.

Diagnosis. Phalloceros spiloura can be diagnosed by the following uniquely derived autapomorphies: (1) the possession of a rounded spot located on the lower half of the caudal peduncle close to the base of lowest caudal-fin rays (Fig. 48); (2) a patch of dark pigmentation on the last anal-fin rays of females (Fig. 48b); (3) halves of gonopodial paired appendix straight and perpendicular to R3 [96-2*] (Fig. 49). Moreover, $P$. spiloura can be distinguished from its congeners by (1) gonapophysis of vertebra 14 straight in adult males [52-2]; and (2) anterior orbital bone present [143-2].

Description. Morphometric data in Tables 11 and 12. Range of SL: 19.4 to $33.6 \mathrm{~mm}$ (females), 18.0 to $22.4 \mathrm{~mm}$ (males). Dorsal-fin rays: 7 [1], $8 *$ [22], 9 [3]. Branched pectoral-fin rays: $7 *$ [23]. Pelvic-fin rays: 5* [6] (males), 5 [21] (females). Anal-fin rays of females: 10 [10], 11 [10]. Anal-fin rays of males: $9 *$ [7]. Branched caudal-fin rays: 11 [5], 12* [13], 13 [3], 14 [1]. Predorsal scales: 14* [13], 15 [6]. Longitudinal series of scales: 28 [8], 29* [18], 30 [2]. Series of scales around caudal peduncle: $16 *$ [26]. Transverse series of scales: $7 *$ [27]. Serrae on R4p: 12 [2], 13 [2], 14* [1], 15 [1]. Epipleural ribs: 11 [5], 13 [1]. Pleural ribs: 13 [3], 14 [3]. Vertebrae: 31 [1], 32 [5]. Female urogenital papilla right curved, located laterally. Border of anal aperture in contact with first anal-fin ray or very close to it (Fig. 52).

Color in alcohol. Eye silvery brown with greenish brown pupil. Ground color cream, darker in upper half. Upper region of flanks and head densely covered with brown chromatophores.

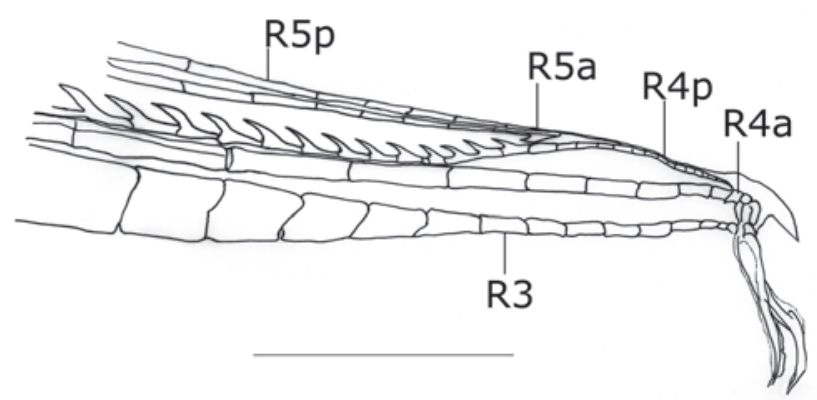

Fig. 49. Gonopodium tip of Phalloceros spiloura, MCP 29270. (a) ventrolateral view; (b) lateral view. R3, R4a, R4p, R5a, R5p indicate gonopodial rays. Scale bar $1 \mathrm{~mm}$.
Border of scales and subjacent skin replete with brown chromatophores, more concentrated at short distance from scale border, conferring reticulate pattern to body sides, mainly on upper half. Brown chromatophores scattered through whole body, more concentrated on dorsal portion, mainly on head, snout, opercle, and ventral surface of mandible. Faint vertical bars along flanks. Dorsal-fin membrane hyaline. Band of dark chromatophores on distal border of dorsal fin. Band of dark chromatophores near dorsal-fin base, more concentrated posteriorly, forming distinct spot. Dark brown line along R3. Pectoral-, pelvic-, anal, and caudal-fin rays unpigmented. Rounded spot on lower half of caudal peduncle close to base of lowest caudal-fin rays. Patch of dark pigmentation on last anal-fin rays of females.

Etymology. From the Greek $\sigma \pi \imath \lambda \mathrm{s}$ [ [= spílos], n. m. nom. sg., meaning spot + oura [= ourá], n. f. nom. sg., meaning tail, alluding to the presence of a rounded spot on close to base of lowest caudal-fin rays. A noun in apposition.

Distribution. Rio Iguaçu and coastal drainages of Rio Grande do Sul and Santa Catarina (Fig. 7), including the rio Tubarão, rio Itajaí-Açu, rio Itapocu, rio Mampituba, rio Cubatão (North), rio Tramandaí drainages.

Remarks. One specimen (MCP 10659) lacks left caudal spot.

\section{Phalloceros reisi, new species}

Figs. 50, 51

Phalloceros sp. n. L Lucinda \& Reis (2005).

Holotype. MCP 30407, creek on Iporanga exit to Apiaí, Apiaí, São Paulo, Brazil, 24³1’37"S 4849’55"W, 10 Jan 1997, R.E. Reis et al. Paratypes. Brazil. São Paulo. Rio Iporanga drainage. MCP 20571, 10, Iporanga, ribeirão do Monjolo, nearby mouth, in Bairro da Serra, ca. 13 km WNW from Iporanga, 243' $16^{\prime \prime}$ S 4840’45"W, 10 Jan 1997, R.E. Reis et al. MCP 20579, 117/4*, collected with the holotype. MCP 20581, 17, Iporanga, dried creek in Bairro da Serra, ca. 13 km WNW from Iporanga. 2433’04"S 4841’08"W, 10 Jan 1997, R.E. Reis et al. MCP 20589, 10, Iporanga, rio Betari on bridge at Bairro da Serra, ca. 13 km WNW from Iporanga, 24³3’16"S 4840’45"W, 10 Jan 1997, R.E. Reis et al. MCP 27004, 8, Iporanga, rio Betari on bridge at Bairro da Serra, ca. $16 \mathrm{~km}$ WNW from Iporanga, 22 Jun 1984, J.C. Garavello et al.

Non-types. Rio juquiá. MZUSP 49328, 2, Juquitiba, creek tributary to rio Juquiá, nearby Hotel Belvedere, on dirty road to Juquitiba. Rio Tietê Headwaters. MCP 20583, 9, Mogi das Cruzes, rio Taiaçupeba close to Substação Elétrica de Tijuco Preto in Taiaçupeba, $23^{\circ} 42^{\prime} 21^{\prime \prime S ~ 46 ¹ 7 ’ 53 " W . ~ M C P ~ 20568, ~ 74, ~ P a r a n a p i a c a b a, ~ c r e e k ~ c a . ~}$ 2 km NW from Paranapiacaba, on road from Campo Grande to Paranapiacaba, 2346’21"S 46¹8'52"W. MCP 25525, 11, Salesópolis, rio Paraitinga, at the side of the avenue in Salesópolis, 2331'43"S 4551'32"W. MCP 25527, 30, Salesópolis, rio Paraitinga, $23^{\circ} 31^{\prime} 26^{\prime \prime S ~ 45 ~ 48 ’ 9 " W . ~ M C P ~ 25528, ~ 29, ~ S a l e s o ́ p o l i s, ~ r i o ~ P a r a i t i n g a ~}$ in Cachoeira da Porteira, 233'ㄱ'37"S 4545'52"W. USNM 309786 , 46, headwaters of rio Tietê, Alto da Serra, half-way on road be- 


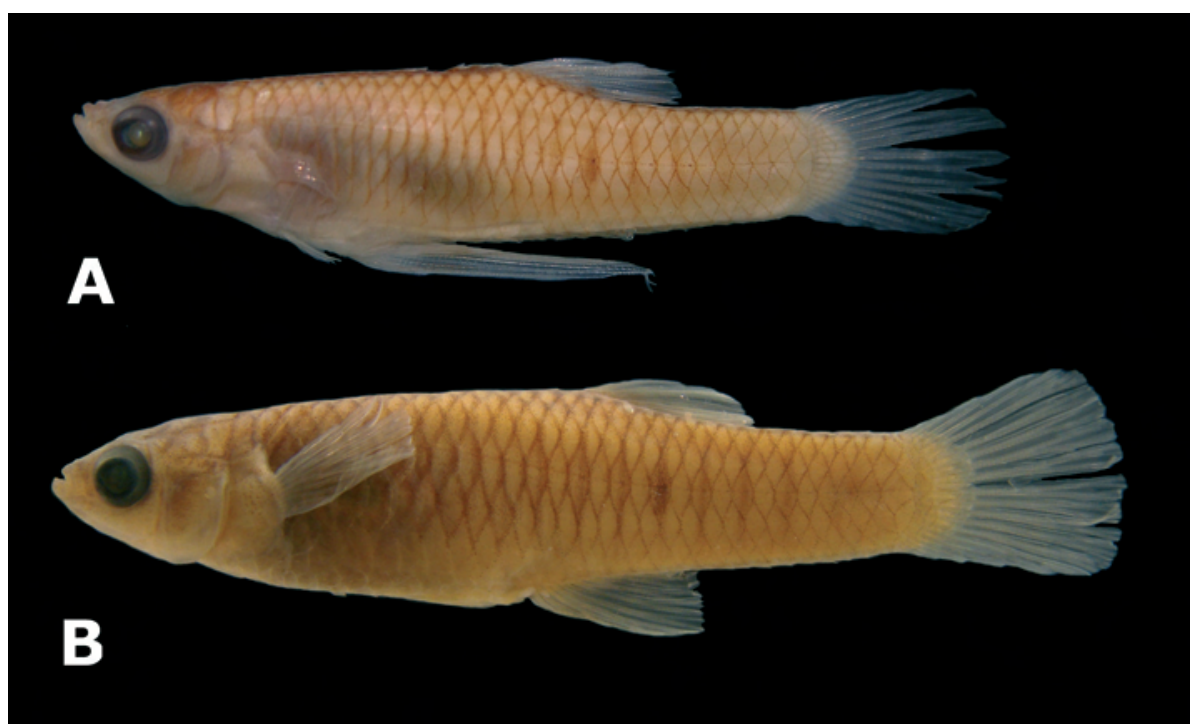

Fig. 50. Phalloceros reisi. (A) Holotype, male, 27.3 mm SL, MCP 30407, creek on Iporanga exit to Apiaí, Apiaí, São Paulo, Brazil; (B) paratype, female, MCP 20579, 34.6 mm SL, collected with the holotype.

tween Campo Grande and Paranapiacaba, E of Alto da Serra a couple of miles. USNM 309788, 233, headwaters of rio Tietê, small stream to $\mathrm{N}$ of Paranapiacaba, about 2-3 km from SW. Headwaters of Rio Paraíba do Sul. MZUSP 47192, 14, Mogi das Cruzes, ribeirão Guararema, Luiz Carlos (dirty road Luiz Carlos - Sabaúna, at the side of RFFSA). Small coastal drainages. MCP 31133, 86, Cubatão, stream affluent to rio Quilombo ca. $3.6 \mathrm{~km}$ from road SP 55, 2350’33"S 46¹9’41"W. MCP 31140, 56, Cubatão, stream affluent to rio Quilombo ca. $0.5 \mathrm{~km}$ from road SP 55, 2351'23"S 46 $20^{\circ} 54^{\prime \prime W}$. MCP 31143, 31, Iporanga, rio Betari ca. $2 \mathrm{~km}$ from Iporanga, 2436’11"S 48³6’39"W. MCP 31188, 10, Cubatão, creek at Quilombo ca. $2.1 \mathrm{~km}$ from road SP 55 (affluent to rio Quilombo).

Diagnosis. Phalloceros reisi can be distinguished from its congeners but $P$. megapolos, $P$. spiloura, $P$. malabarbai, $P$. alessandrae, P. buckupi, P. uai, P. lucenorum, P. pellos, and $P$. anisophallos by (1) the female urogenital papilla curved to the right, located laterally (vs. slightly left turned and with a lateral ramus or straight located along midventral line) and (2) border of the anal aperture in contact with the first anal-fin ray or very close to it (vs. separated from first anal-fin ray by the female urogenital papilla).

Phalloceros reisi can be distinguished from its congeners but $P$. spiloura, $P$. uai, $P$. lucenorum, $P$. pellos, and $P$. anisophallos by (1) the absence of the right hook and presence of the left one ( $v s$. absence or presence of left and right hooks), and (2) gonopodial appendix asymmetrical; its halves different from each other; right half wider than left one (vs. gonopodial appendix symmetrical; its halves similar to each other).

Phalloceros reisi can be distinguished from $P$. spiloura by the absence of a caudal peduncle spot ( $v s$. presence of caudal peduncle spot); from $P$. uai by the presence of a wide and square-shaped lateral spot in large specimens (vs. absence of such spot); from $P$. lucenorum by rectangular tip of hook on left half of gonopodial appendix (vs. rounded tip); from $P$. anisophallos by the lateral spot in adult females very narrow, forming a vertically elongated bar covering up to the length corresponding to two scales length in horizontal direction and 2-4 scales in vertical direction (vs. absent, small, or elliptical to roundish, but never forming a vertical bar lateral spot in adult females); from $P$. pellos by (1) the background coloration light brown or yellow (vs. dark brown) and (2) margin of scales on prepelvic region not visible, not bordered by dark chromatophores, forming a light, plain yellow region (Fig. 50) (vs. margin of scales on prepelvic region clearly defined and bordered by dark chromatophores). The lateral spot absent or small and discrete not covering one or two scales in horizontal or vertical directions differs $P$. reisi from $P$. lucenorum and $P$. pellos.

Description. Morphometric data in Tables 9 and 10. Range of SL: 23.2 to $49.9 \mathrm{~mm}$ (females), 17.0 to $27.2 \mathrm{~mm}$ (males). Dorsalfin rays: 7 [1], 8* [98], 9 [4]. Branched pectoral-fin rays: 5 [2], 6 [25], 7* [64]. Pelvic-fin rays: 5* [23] (males), 5 [74] (females). Anal-fin rays of females: 10 [21], 11 [55]. Anal-fin rays of males: 9* [26]. Branched caudal-fin rays: 10 [8], 11 [28], 12* [39], 13 [4]. Predorsal scales: 12 [1], 13 [5], 14* [80]. Longitudinal series of scales: 28 [16], 29* [76], 30 [6]. Series of scales around caudal peduncle: $16 *$ [98]. Transverse series of scales: 6 [1], 7* [96]. Serrae on R4p: 8 [8], 9 [12], 10* [1]. Epipleural ribs: 10 [1], 11 [2], 13 [1]. Pleural ribs: 14 [3], 15 [1]. Vertebrae: 31 [1], 32 [3]. Female urogenital papilla right curved, located laterally. Border of anal aperture in contact with first anal-fin ray or very close to it. Halves of gonopodial paired appendix sickle like. Medial corner absent. Hook on left half of gonopodial paired appendix. Right hook absent (Fig. 51).

Color in alcohol. Eye black with greenish brown pupil. Ground color cream, darker in upper half. Upper region of flanks and head densely covered with brown chromatophores. Border 


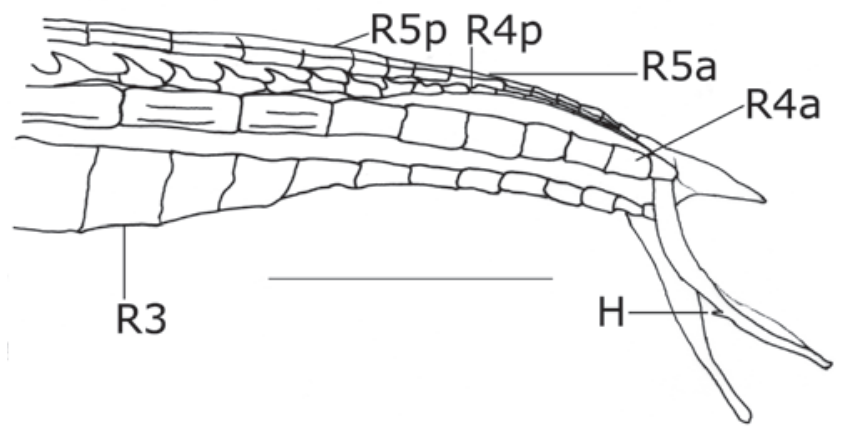

Fig. 51. Gonopodium tip of Phalloceros reisi, MCP 20579. (a) ventrolateral view; (b) lateral view. R3, R4a, R4p, R5a, R5p indicate gonopodial rays. $\mathrm{H}=$ hook. Scale bar $1 \mathrm{~mm}$.

of scales and subjacent skin replete with brown chromatophores, more concentrated at short distance from scale border, conferring reticulate pattern to body sides, mainly on upper half. Brown chromatophores scattered through whole body, more concentrated on dorsal portion, mainly on head, snout, opercle, and ventral surface of mandible. Lateral spot corresponding to one scale in size, or smaller; inconspicuous, or absent in large females. Lateral spot located over $17^{\text {th }}$ or $18^{\text {th }}$ scale of longitudinal series, or between them. Faint vertical bars along flanks; sometimes absent. Dorsal-fin membrane bearing band of dark chromatophores on distal border of dorsal fin. Band of dark chromatophores near dorsal-fin base, more concentrated posteriorly. Dark brown line along base of R3. Pectoral-, pelvic-, anal, and caudal-fin rays unpigmented. Few chromatophores on first three anal-fin rays of females.

Etymology. The specific name reisi (n. m. gen. sg.) is a patronym for Roberto E. Reis, in recognition of his many contributions to Neotropical ichthyology.

Distribution. Headwaters of rio Tietê, rio Paraíba do Sul, rio Ribeira de Iguape, and small coastal drainages in São Paulo State of Brazil (Fig. 7).

Remarks. A single lot is known from the rio Juquiá drainage. Maybe this species is not sufficiently sampled in this area.

\section{Key to species of Phalloceros:}

1. Female urogenital papilla slightly left turned and with a lateral ramus (Fig. 16). Hooks of the gonopodial appendix large and sickle like (Figs. 14, 17, 20) ...

1'. Female urogenital papilla turned to the right (Fig. 52) or straight along midline (Fig. 53) Lateral ramus absent. Hooks of the gonopodial appendix absent or present, but never large and sickle like (e.g. Fig. 28) ......................................... 4

2. Lateral spot present ................................................................ 3

2'. Lateral spot absent ............................. Phalloceros aspilos (Rio Parati-Mirim drainage, Rio de Janeiro)
3. Lateral spot densely pigmented, rectangle like, horizontally covering the length corresponding to two or three scales length (Fig. 15) . Phalloceros leptokeras (lower portions of rio Paraíba do Sul drainage)

3'. Lateral spot normally pigmented, vertically elongated, and horizontally covering the length corresponding to one scale length (Fig. 13) ..................... Phalloceros tupinamba (rio Itamambuca and rio Macacu drainages)

4. Female urogenital papilla straight, located along midventral line and between the anus and the base of first anal-fin ray (Fig. 53) 14

4'. Female urogenital papilla curved to the right, located laterally (Fig. 52). Border of the anal aperture in contact with the first anal-fin ray or very close to it ................................. 5

5. Caudal peduncle spot absent .................................................. 6

5'. Caudal peduncle spot present (Fig. 48)

Phalloceros spiloura (Rio Tubarão, rio Itajaí-Açu, rio Iguaçu, rio Itapocu, rio Mampituba, rio Cubatão [Norte], rio Tramandaí drainages, coastal drainages of Rio Grande do Sul e Santa Catarina)

6. Gonopodium appendix normally developed, not expanded in wing like projections

6'. Gonopodium appendix greatly expanded in wing like projections (Fig. 37) ............................ Phalloceros megapolos (drainages of the rio São João, rio Cubatão [Norte] and small adjacent drainages, which flows to the Baía de Guaratuba in Santa Catarina)

7. Halves of gonopodial paired appendix slender, not sickle like, and similar to each other, bearing a medial corner. Hook on both halves of gonopodial paired appendix. Both hooks large, downward directed, and located at the corner of gonopodial appendix (Figs. 33, 35)

7'. Halves of gonopodial paired appendix sickle like; medial corner absent. Hook on left half of gonopodial paired appendix only. Right hook absent. Left hook small, directed downward or up- and forward, and located close to the base of gonopodial appendix (Figs. 39, 43, 45, 47, 51) ...... 9

8. Gonopodial appendix long and strongly arched at the distal tip. Distal portion bent upward. Left and right halves free not coalescent at the base (Fig. 35)

Phalloceros malabarbai

(Itapoá, Santa Catarina)

8'. Gonopodial appendix long and straight at the distal tip. Distal portion straight and oblique, forming a $45^{\circ}$ angle with the vertical axis. Left and right halves coalescent at the base (Fig. 33) .... Phalloceros alessandrae (flooded areas on margins nearby Antonina [Paraná] and rio Dois de Fevereiro, which flows into the Baía de Paranaguá)

9. Halves of gonopodial paired appendix wide and distinct from each other; right half wider than left one (Figs. 39, 41, $45,47,51)$ 10

9'. Halves of gonopodial paired appendix slender and similar to each other (Fig. 43) ...................... Phalloceros buckupi (rio Jacareí drainage and neighbouring, which flows to the 


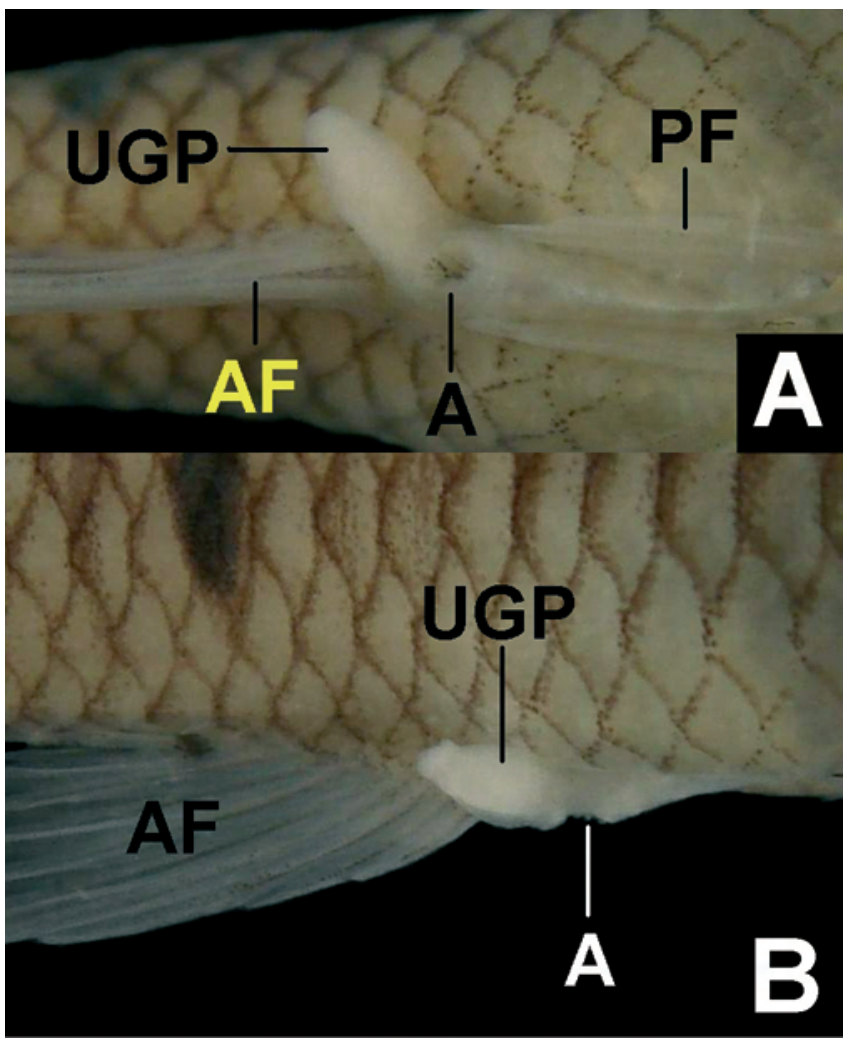

Fig. 52. Urogenital region of female of Phalloceros spiloura, MCP 29270. (A) ventral view; (B) lateral view of right side. A = anus; $\mathrm{AF}=$ anal fin; $\mathrm{PF}=$ pelvic fin; $\mathrm{UGO}=$ urogenital opening; UGP = urogenital papilla. Scale bar $1 \mathrm{~mm}$.

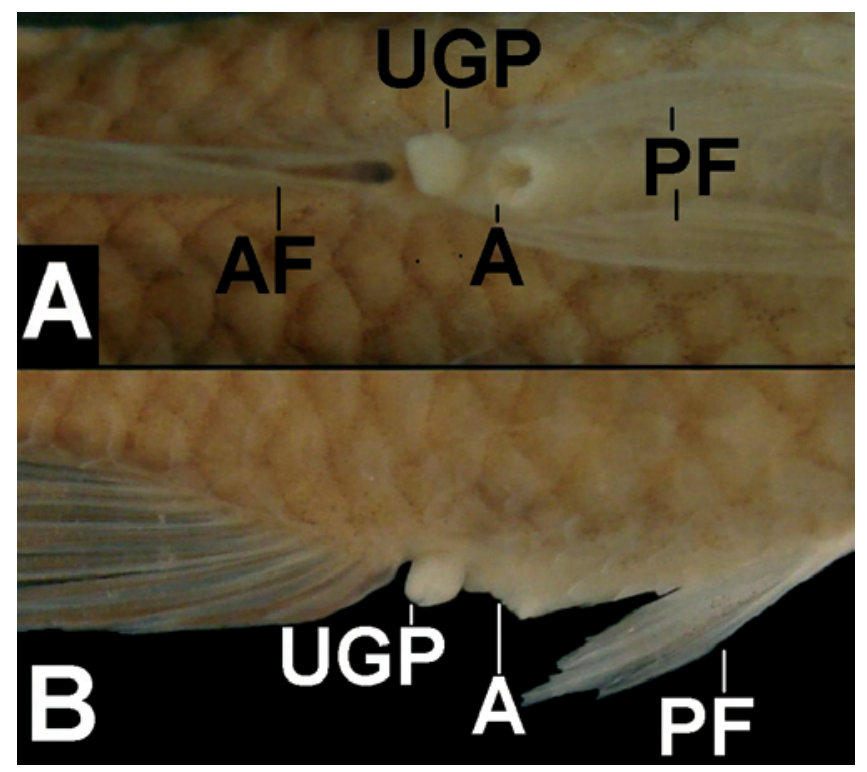

Fig. 53. Urogenital region of female of Phalloceros titthos, MZUSP 79670. (A) ventral view; (B) lateral view of left side, pelvic fin. $\mathrm{A}=$ anus; $\mathrm{AF}=$ anal fin; $\mathrm{UGO}=$ urogenital opening; UGP = urogenital papilla. Scale bar $1 \mathrm{~mm}$.
Baía de Paranaguá in the coast of Paraná State of Brazil)

10. Lateral spot of large specimens absent or when present narrow, elliptical to roundish, or vertically elongated but never square-shaped (Figs. 38, 44, 46, 50) .. 11

10'. Lateral spot wide and square-shaped in large specimens (Fig. 40) Phalloceros uai (rio das Velhas, rio São Francisco)

11. Hook on left half of gonopodial appendix with a rounded or pointed tip (Figs. 45, 47, 51) .. 12

11 '. Hook on left half of gonopodial appendix with a rectangular tip (Fig. 39) Phalloceros lucenorum (rio Juquiá drainage)

12. Hook on left half of gonopodial appendix located approximately midway to the distal third of gonopodial appendix (Fig. 51). Lateral spot of adult females absent, small, or elliptical to roundish, but never forming a vertical bar (Fig. 50). .. 13

12'. Hook on left half of gonopodial appendix near its tip, located approximately between distal quarter and distal third of gonopodial appendix (Fig. 45). Lateral spot of adult females very narrow, forming a vertically elongated bar covering at most the length corresponding to two scales length in horizontal direction and 2-4 scales in vertical direction (Fig. 44) ..... Phalloceros anisophallos (drainages of rio Parati, rio Barra Grande, rio São Roque and rio Itinguçu - small coastal drainages of the State of Rio de Janeiro)

13. Hook on left appendix very small, visible only in large males and under a high magnification (Fig. 47). Lateral spot always present and evident, not covering more than two scales in horizontal or vertical directions (Fig. 46)

Phalloceros pellos

(Paranaguá, Paraná)

13’. Hook on left appendix larger (Fig. 51). Lateral spot absent or small and discrete not covering the length corresponding to one or two scales length in horizontal or vertical directions (Fig. 50) Phalloceros reisi (headwaters of rio Tietê, rio Paraíba do Sul, and rio Ribeira de Iguape)

14. Well-defined ocellated lateral spot, roundish to rounded (very rarely absent) (Figs. 2, 5, 30) . 15

14'. Non-ocellated lateral spot, elliptical, vertically elongated, or absent (Figs. 8, 10, 21, 23, 25, 27) ... 17

15. Ten, rarely 9, anal-fin rays in females ........................... 16 15 '. Eleven anal-fin rays in females.

Phalloceros mikrommatos (rio João de Tiba drainage, a coastal drainage in the Bahia State)

16. Postorbital length 39.2-42.2 \% SL (females) and 36.7-42.3 $\%$ SL (males) . Phalloceros leticiae (the upper rio Araguaia)

16'. Postorbital length 24.8-39.3 \% SL (females), and 29.3-38.2 $\%$ SL (males) Phalloceros ocellatus (coastal drainages of Bahia and Espírito Santo States between Prado and Sooretama) 
17. Gonopodial appendix hook absent (Fig. 10) 18

17'. Gonopodial appendix hook present (Fig. 28) 19

18. Sexual dimorphism on number of dorsal-fin rays: males with 8 rays (very exceptionally seven) and females with seven rays (very exceptionally 8). Lateral spot absent (Fig. 9) . Phalloceros heptaktinos

(tributaries of arroio dos Ratos, Jacuí basin, in Mariana Pimentel, Rio Grande do Sul)

18 '. Eight dorsal-fin rays in both sexes. Lateral spot usually present Phalloceros caudimaculatus (laguna dos Patos system, drainages of rio Ibicuí and Negro [affluent to rio Uruguai], Tramandaí, Mampituba, coastal drainages of Rio Grande do Sul, Uruguay and Argentina).

19. Eight dorsal-fin rays (very rarely seven or nine) 20

$19^{\prime}$. Nine dorsal-fin rays Phalloceros enneaktinos (córrego da Toca do Boi, Rio de Janeiro)

20. Symphyseal papillae absent 21

20'. Symphyseal papillae present (Fig. 26) ..Phalloceros titthos (coastal drainages flowing to Baia de Guaratuba and Baia de Paranaguá in Paraná State)

21. Small size. Appendix hook minute in adults, forming a lateral minute protuberance (Fig. 22). Hook absent or tiny (rarely) in juveniles, never situated on the appendix corner. Juveniles never with skin covering the tip of appendix. Distal half of appendix approximately as wide as (or slightly narrower than) proximal half (Fig. 22)

. Phalloceros elachistos

(drainages of rio Doce, rio Santa Maria da Vitória, rio Jucu, and rio Timbuí, coastal drainages of Espírito Santo)

21'. Small to large size. Appendix hook medium or large in adults (Fig. 28). Hook present in juveniles and located on the appendix corner. Juveniles with skin covering the tip of appendix. Distal half of appendix conspicuously narrower than proximal half (Fig. 28)

Phalloceros harpagos

(Rio Paraná-Paraguai basin and coastal drainages from rio Itaboapana in Espírito Santo to rio Araranguá in Santa Catarina)

\section{Discussion}

Phalloceros is a well-diagnosed, monophyletic genus, whose phylogenetic position in the subfamily Poeciliinae was recently discussed by Lucinda \& Reis (2005). According to these authors Phalloceros is the sister-group of Phallotorynus Henn, 1916 which together with Cnesterodon Garman, 1895 forms the tribe Cnesterodontini (see Lucinda, 2005b, Lucinda \& Reis, 2005; and Lucinda et al. 2005 for further discussion).

Lucinda \& Reis (2005) were the first to attempt a solution for the recognition or diagnosis of a monophyletic Phalloceros. Previous diagnoses were non-cladistic. How- ever, Phalloceros was monotypic and the diagnosis of the species was the diagnosis for the genus. The lack of previous attempts to diagnose Phalloceros cladistically were partially explained by the monotypy of the genus. Definitions of monotypic genera are somewhat merged with the species definition. Eigenmann (1907) erected the genus diagnosing it by the presence of "antler-like processes" or "antler-like structures" [= paired appendix] at tip of R4a (Eigenmann, 1907: 427 \& 431, respectively). However, the paired appendix is attached to R3 not to R4a (Rosen \& Bailey, 1963; Lucinda \& Reis, 2005). Rosen \& Bailey (1963) also proposed this feature as diagnostic for Phalloceros. Lucinda \& Reis (2005) regarded the presence of the paired appendix at the tip of R3 as an uniquely derived and unreversed synapomorpy shared by all Phalloceros species.

Eigenmann (1907) also mentioned teeth morphology as diagnostic for Phalloceros: “(...) the presence of outer series of spoon-oar-shaped teeth, somewhat expanded at tip and bent backward, close set, their margins in contact near their tips; much smaller teeth, triangular at tips, slightly contracted at base, forming one or more series behind the larger teeth." Nevertheless, this teeth morphology is not unique to Phalloceros and is widespread among poeciliine genera. Following Eigenmann (1907: 431), the length of the intestine, which is "twice as long as the entire fish," is another diagnostic feature for Phalloceros. This characther was not surveyed by Lucinda \& Reis (2005).

The comparative examination of samples of Phalloceros allowed the recognition of twenty-one distinct, previously unrecognized or undiscovered species on the genus. The color pattern, meristic, and morphometric characters support the recognition of these new species as distinct from their congeners (see diagnoses). One of the reasons for this previously undetected diversity may be related to neglect of potential diagnostic features such as the morphology of the gonopodial appendix and the female urogenital papilla. Additionally, Phalloceros and other poeciliids have long been neglected by fish systematists, although this situation is changing.

The intrageneric phylogenetic relationships are far from satisfactory. At present, the cladogram which expresses the up-to-date state of knowledge of the relationships among Phalloceros species, exhibits many polytomies (Fig. 1). Discovery of new characters and/or species would be effective in defeating this polytomic situation. Unfortunately, the lack of resolution across much of the cladogram severely limits the historical biogeographic information available. Although the lack of resolution precludes unambiguous assertions, some tentative biogeogeophical remarks on Phalloceros distribution are outlined below.

Phalloceros species as well as almost all cnesterodontines (with rare exceptions) are found in southern South American drainages, one of the eight areas of endemism for poeciliines in the American continent identified by Lucinda \& Reis (2005). Phalloceros species are also found in five of the eigth re- 
gions of endemism identified by Vari (1988) for the ichthyofauna of cis-Andean South America: (1) coastal drainages above the mouth of the rio Paraíba do Sul, (2) rio Tocantins drainage, (3) rio São Francisco drainage, (4) Paraguay (rio Paraguay, Uruguay, lower Paraná drainages, and coastal drainages south of São Paulo), and (5) upper rio Paraná. It is remarkable that most species inhabit the "Paraguay" and the "Coastal" regions of endemism. Few species are found in the São Francisco (P. uai), upper Paraná (P. harpagos), and Tocantins (P. leticiae).

It is also noteworthy that several species have a very limited distribution, e.g. P. enneaktinos, whereas P. harpagos exhibits a huge distribution range. This pattern of one widely distributed species plus several confined species is shared by some other neotropical fishes.

The coastal drainages of Paraná and Santa Catarina States represent a highly endemic area for Phalloceros, although associated geological events are unclear or even unknown. Several species of Phalloceros are confined to these drainages. Other teleosts are also restrict to this area, e.g. Deuterodon langei Travassos, 1957; Pimelodella papennheimi Ahl, 1925; Kronichthys lacerta (Nichols, 1919); Pareiorhaphis calmoni (Steindachner, 1907); P. splendens (Bizerril, 1995); P. steindachneri (Miranda Ribeiro, 1918); P. stomias (Pereira \& Reis, 2002); and P. azygolechis (Pereira \& Reis, 2002).

Most basal species of Phalloceros (Clade 95) inhabit the rio Tocantins and rio João de Tiba drainage. Remaining species (Clade 96) inhabit all coastal drainages from Bahia to the Republic of Uruguay as well as the upper Paraná. Most basal species of Clade 96, namely $P$. heptaktinos and $P$. caudimaculatus, are confined to the rio Jacuí, rio Uruguay and neighboring coastal drainages of Rio Grande do Sul and the Republic of Uruguay. Actually, the rio Uruguay drainage seems to represent a barrier to remaining species (Clade 83), for the only species found in the rio Uruguay drainage and neighboring coastal drainages to the south are $P$. heptaktinos and $P$. caudimaculatus. Remaining species (Clade 83) are found in upper Paraná and along coastal drainages to the north, i.e. from the rio Araranguá drainage (the austral boundary) to coastal drainages of Bahia State (the septentrional boundary).

Uniquely derived and unreversed features support very distinct monophyletic and endemic species-groups inside Clade 83. Members of Clade 81 are confined to the rio Paraíba do Sul drainage and neighboring coastal drainages and share hooks on paired gonopodial appendix large and sickle-like and female urogenital papilla left turned. Members of Clade 76 share a female urogenital papilla right turned and are split in two diferent well-coroborated monophyletic lineages: Clade 75, whose members are confined to small coastal drainages between the Baía de Paranaguá (Paraná State) and São Francisco do Sul (Santa Catarina) and share large hooks directed downward and located in the corner of gonopodial appendix, and Clade 74, whose members share hooks on gonopodial paired appendix present only on left half and are distributed in coastal drainages of Rio de Janeiro, São Paulo, and Paraná States as well as in the upper reaches of the rio São Francisco basin.

Most species of Phalloceros conform to a general pattern of allopatric distribution, although some species are sympatric or even syntopic. This is the case of Phalloceros harpagos, which is widely distributed and sympatric with many other species. Two other cases of sympatry (syntopy) are found: (1) Phalloceros heptaktinos and $P$. caudimaculatus and (2) Phalloceros leptokeras, $P$. reisi and $P$. harpagos. These distibution and sympatry/syntopy patterns can probably be explained by several past dispersion events concerning these species.

Phalloceros heptaktinos is sympatric and syntopic with $P$. caudimaculatus in the tributaries of the arroio dos Ratos (Jacuí basin), whereas $P$. leptokeras, $P$. reisi and $P$. harpagos are sympatric in the rio Paraíba do Sul drainage. Phalloceros leptokeras is even syntopic with $P$. harpagos, which could also require a dispersion explanation. However P. leptokeras and $P$. reisi are sympatric but not syntopic. Phalloceros leptokeras is restricted to the middle portions of rio Paraíba do Sul drainage, whereas $P$. reisi inhabits its headwaters. Phalloceros reisi also inhabits the headwaters of rio Tietê, the rio Ribeira de Iguape, and small coastal drainages in São Paulo State of Brazil. The presence of P. reisi in rio Paraíba do Sul and in rio Paraná drainages is congruent with the distribution pattern of Phallotorynus fasciolatus (Lucinda et al., $2005)$ and many other teleosts. As well, the presence of $P$. leptokeras in middle portions of rio Paraíba do Sul drainage and the presence of $P$. reisi in its upper portions is also congruent with the distibution pattern above. Both facts are probably related to and may be explained by the formation of the upper Paraíba do Sul by stream capture of rio Tietê headwaters (Malabarba, 1998). See Malabarba (1998), Weitzman \& Malabarba (1999), and Quevedo \& Reis (2002) for further discussion.

It is very likely that additional Phalloceros species will be discovered in the near future, owing to increasing collecting efforts on poorly sampled and unsampled South-American areas and to continuous increase of attention poeciliid fishes have received in the last years. Much effort must still be directed towards understanding of Phalloceros systematics and biogeography.

\section{Acknowledgments}

For loan of specimens I am deeply indebted to Barbara Brown (AMNH), Dario Mandelburger (MNHNP), John Lundberg (ANSP), Luiz Malabarba (UFRGS), Marcelo Loureiro (ZVC-P), Mark Sabaj (ANSP), Marlise Bemvenuti (FURG), Osvaldo Oyakawa (MZUSP), Paulo Buckup (MNRJ), Peter Barstch (ZMB), Ricardo Rosa (UFPB), Richard Vari (USNM), Roberto Reis (MCP), Scott Schaefer (AMNH), Su- 
san Jewett (USNM), Sven Kullander (NRM), Vinícius Abilhôa (MHNCI), and William Fink (UMMZ). I am also grateful to José Pezzi da Silva, Aloísio Braun and Cíntia Kaefer for curatorial help in MCP. José Pezzi da Silva (MCP) made the maps. I am grateful to Anderson Soares (UNT) and Tiago Carvalho (MCP) who photographed the type specimens. Anderson Soares (UNT) helped me with the drawings. I thank José W. Thomé for help with German texts. The manuscript benefited from reviews by Carlos Lucena, Luiz Malabarba, Márcio Martins, Roberto Reis (all from MCP), Carlos Figueiredo (MNRJ), Ricardo Rosa (UFPB), and one anonymous reviewer. This study was developed during a doctoral programme at the Pontifícia Universidade Católica do Rio Grande do Sul (PUCRS) under advise of Roberto Reis (MCP), and was supported by the Universidade do Tocantins (UNITINS), the Universidade Federal do Tocantins (UFT), and the Fundação Coordenação de Aperfeiçoamento de Pessoal de Nível Superior (CAPES - PICDT doctoral fellowship). PHFL is partially supported by a research grant from the Conselho Nacional de Desenvolvimento Científico e Tecnológico (CNPq process 304838/2005-5).

\section{Literature Cited}

Eigenmann, C. H. 1907. The Poeciliid fishes of Rio Grande do Sul and the La Plata Basin. Proceedings of the United States National Museum, 32: 425-433.

Garman, S. 1895. The Cyprinodonts. Memoirs of the Museum of Comparative Zoology, 19: 1-179.

Garman, S. 1896. Cross fertilization and sexual rights and lefts among vertebrates. American Naturalist, 30: 232.

Gosline, W. A. 1949. The sensory canals of the head in some Cyprinodont fishes, with particular reference to the genus Fundulus. Occasional Papers of the Natural History Museum, University of Kansas, 519: 1-17.

Henn, A. W. 1916. On various South American Poeciliid fishes. Annals Carnegie Museum, 10: 93-142.

Hensel, R. 1867. Beiträge zur näheren Kenntnis der Brazilianischen Provinz São Pedro do Rio Grande do Sul. Zeitschrift der Gesellschaft für Erdkunde, 2(3): 227-269 \& 342-376.

Hensel, R. 1868. Beiträge zur Kenntnis der Wirbelthiere Südbrasiliens. Archives für Naturgeschichte, 34: 323-375.

Hensel, R. 1870. Beiträge zur Kenntnis der Wirbelthiere Südbrasiliens. Archives für Naturgeschichte, 1: 50-91.

Langer, W. F. 1913. Beiträge zur Morphologie der viviparen Cyprinodontiden. Morphologisches Jahrbuch, 47: 193-307.

Leviton, A. E. \& R. H. Gibbs, Jr. 1988. Standards in herpetology and ichthyology standard symbolic codes for institution resource collections in herpetology and ichthyology. Copeia, 1988: 280282.

Leviton, A. E., R. H. Gibbs, Jr., E. Heal \& C. E. Dawson. 1985. Standards in Herpetology and Ichthyology: Part I. Standard Symbolic for Institutional Resource Collections in Herpetology and Ichthyology. Copeia, 1985: 802-832.

Lucinda, P. H. F. 2003. Family Poeciliidae. Pp. 555-581. In: Reis, R. E.; S. O. Kullander \& C. J. Ferraris Jr. (Eds.). Check list of the freshwater fishes of South and Central America. Porto Alegre, Edipucrs, 729p.

Lucinda, P. H. F. 2005a. Systematics of the genus Cnesterodon Garman, 1895 (Cyprinodontiformes, Poeciliidae, Poeciliinae). Neotropical Ichthyology, 3: 259-270.

Lucinda, P. H. F. 2005b. Systematics and biogeography of the genus Phalloptychus Eigenmann, 1907 (Cyprinodontiformes, Poeciliidae, Poeciliinae). Neotropical Ichthyology, 3: 373-382.

Lucinda, P. H. F. \& R. E. Reis. 2005. Systematics of the subfamily Poeciliinae Bonaparte (Cyprinodontiformes, Poeciliidae). Neotropical Ichthyology, 3: 1-60.

Lucinda, P. H. F., R. S. Rosa \& R. E. Reis. 2005. Systematics and biogeography of the genus Phallotorynus Henn, 1916 (Cyprinodontiformes, Poeciliidae, Poeciliinae). Copeia, 2005: 609-631.

Malabarba, M. C. L. S. 1998. Phylogeny of fossil Characiformes and paleobiogeography of the Tremembé Formation, São Paulo, Brazil, Pp. 69-84. In: Malabarba, L. R.; R. E. Reis, R. P. Vari, Z. M. S. Lucena \& C. A. S. Lucena (Eds.). Phylogeny and Classification of Neotropical Fishes. Porto Alegre, Edipucrs, 603p.

Paepke, H. -J. \& L. Seegers. 1986. Kritischer Katalog der Typen und Typoide der Fischsammlung des Zoologischen Museums Berlin. Teil 1: Atheriniformes. Mitteilungen aus dem Museum für Naturkunde in Berlin, Zoologische Reihe, 62: 135-186.

Papavero, N. 1973. Essays on the history of Neotropical dipterology. São Paulo, Museu de Zoologia da Universidade de São Paulo. 446p.

Parenti, L. R. 1981. A phylogenetic and biogeographical analysis of Cyprinodontiform fishes (Teleostei, Atherinomorpha). Bulletin of the American Museum of Natural History, 168: 341-557.

Phillipi, E. 1908. Fortpflanzungsgeschichte der viviparen Teleosteer. Glaridichthys januarius und G. decem-maculatus in ihrem Einfluss auf Lebensweise, makroskopische und mikroskopische Anatomie. Zoologisches Jahrbuch, 27: 1-94.

Quevedo, R. \& R. E. Reis. 2002. Pogonopoma obscurum: a new species of loricariid catfish (Siluriformes: Loricariidae) from southern Brazil, with comments on the genus Pogonopoma. Copeia, 2002: 402-410.

Rauchenberger, M. 1989. Systematics and biogeography of the genus Gambusia (Cyprinodontiformes: Poeciliidae). American Museum Novitates, 2951: 1-74.

Regan, C. T. 1913. A revision of the Cyprinodont fishes of the subfamily Poeciliinae. Proceedings of the Zoological Society, London, 5: 977-1019.

Rosen, D. E. \& R. M. Bailey. 1963. The poeciliid fishes (Cyprinodontiformes) their structure, zoogeography and systematics. Bulletin of the American Museum of Natural History, 126: 1-176.

Rosen, D. E. \& M. Gordon. 1953. Functional anatomy and evolution of male genitalia in Poeciliid fishes. Zoologica, 38: 1-47.

Rosen, D. E. \& J. R. Mendelson. 1960. The sensory canals of head in Poeciliid fishes (Cyprinodontiformes), with reference to dentitional types. Copeia, 1960: 203-210.

Taylor, W. R. \& G. C. Van Dyke. 1985. Revised procedures for staining and clearing small fishes and other vertebrates for bone and cartilage study. Cybium, 9: 107-119.

Vari, R. P. 1988. The Curimatidae, a lowland Neotropical fish family 
(Pisces: Characiformes); distribution, endemism, and phylogenetic biogeography. Pp. 313-348. In: Heyer W. R. \& P. E. Vanzolini (Eds.). Neotropical distribution patterns: Proceedings of a 1987 Workshop. Academia Brasileira de Ciência, Rio de Janeiro, 488p.

Weitzman, S. H. \& L. R. Malabarba. 1999. Systematics of Spintherobolus (Teleostei: Characidae: Cheirodontinae) from Eastern Brazil. Ichthyological Exploration of Freshwaters, 10: $1-43$.

Accepted February 2008

Published June 28, 2008 